\title{
METODE ELEMEN HINGGA RANAH FREKUENSI UNTUK SIMULASI PANDU GELOMBANG DALAM MATLAB/OCTAVE
}

\author{
A.D. Garnadi \\ H. Alatas \\ S. Nurdiati \\ L. Yuliawati \\ Pendamping: Dr. Diah Chaerani (Dept. Matematika UNPAD) \\ PERSAMAAN DIFERENSIAL PARSIAL, \\ ANALITIK DAN METODE ELEMEN HINGGA, \\ SERTA APLIKASINYA
}

ITB Press

2019 
A.D. Garnadi ${ }^{a, 2, \dagger}$, H. Alatas $^{a, 1}$, S. Nurdiati ${ }^{2}$, L. Yuliawati ${ }^{a, 3}$ ${ }^{a}$ Research Cluster for Dynamics and Complex System,

FMIPA, Institut Pertanian Bogor,

${ }^{1}$ Dept. Fisika, Institut Pertanian Bogor,

${ }^{2}$ Dept. Matematika, Institut Pertanian Bogor

Jl. Meranti, Kampus IPB Darmaga, Bogor 16680

${ }^{3}$ STKIP Sebelas April Sumedang, Sumedang

$\dagger$ Penulis Utama 
Judul Buku:

METODE ELEMEN HINGGA RANAH FREKUENSI UNTUK SIMULASI

PANDU GELOMBANG DALAM MATLAB/OCTAVE

Penulis:

Drs Agah Garnadi, GradDipSci (ANU)

Prof. Dr. Husin Alatas, MSi

Dr. Sri Nurdiati, MSc

Dr. Lia Yuliawati, MSi

Desain Sampul \& Penata Isi: -

Korektur : -

Jumlah Halaman:

100 halaman +10

\section{Edisi/Cetakan:}

Cetakan Pertama, ------------- 2019

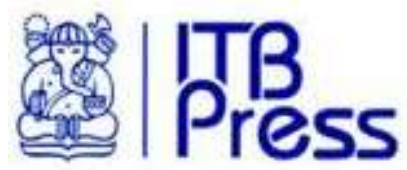

ISBN : 978-623-7165-90-3 
PERSAMAAN DIFERENSIAL PARSIAL, ANALITIK DAN METODE ELEMEN HINGGA, SERTA APLIKASINYA

\author{
METODE ELEMEN HINGGA RANAH FREKUENSI \\ UNTUK \\ SIMULASI PANDU GELOMBANG DALAM MATLAB/OCTAVE
}

ISBN : 978-623-7165-90-3

e-Book DOI :10.31227/osf.io/96ksb 
Blank 


\section{Daftar Isi}

1 PERSAMAAN HELMHOLTZ 1

1.1 Persamaan Helmholtz

2 Metode Elemen Hingga Ranah Frekuensi :

Hampiran Galerkin $\quad 6$

3 LATIHAN $\quad \mathbf{2 7}$

3.1 Latihan 1. Pandu Gelombang Dua Lapis . . . . . . . . . . . . . . 28

3.2 Latihan 2. Test Dengan Solusi. . . . . . . . . . . . . . . . . 30

3.3 Latihan 3. Geometri Bahan Berbeda. . . . . . . . . . . . . . . . 31

3.4 Latihan 4. Perambatan Gelombang Dalam Ruang Akibat Sumber WiFi. . . . . . . . . . . . . . . . . . 32

3.5 Latihan 5. Syarat Batas Serap . . . . . . . . . . . . . 33

3.6 Latihan 6. Geometri Cincin . . . . . . . . . . . . . . . . . 34

3.7 Latihan 7. Tomografi Microwave Memanjang . . . . . . . . . . 35

3.8 Latihan 8. Tomografi Microwave Melintang . . . . . . . . . . . 37

3.9 Latihan 9. Biosensor Bakteria Berlapis. . . . . . . . . . . . . 38

3.10 Latihan 10. Biosensor Resonator Cincin. . . . . . . . . . . . . . 39

3.11 Latihan 11. Biosensor Sisir/bergerigi Plasmonik . . . . . . . . . 40

3.12 Latihan 12. Biosensor Plasmonik Berceruk Dalam. . . . . . . . . 41

3.13 Latihan 13. SPR (Surface Plasmon Resonance) Sensor. . . . . . 42

3.14 Latihan 14. Sel Surya Plasmonik. . . . . . . . . . . . . . . . . . 43

3.15 Latihan 15. Sel Surya Plasmonik dengan PML. . . . . . . . . . . 44

3.16 Latihan 16. Alat uji NDT (Non Destructive Testing) pada gelombang THz. . . . . . . . . . . . . . . . . . . 45

3.17 Latihan 17. Nanowire. . . . . . . . . . . . . . . . . . . 47

3.18 Latihan 18. Antena Nano . . . . . . . . . . . . . . . . . . 48

3.19 Latihan 19. Antena Nano Pemanen Energi Surya. . . . . . . . . 49

3.20 Latihan 20. Antena Nano Asimetrik. . . . . . . . . . . . . . 50

4 Penutup $\quad 51$

5 OCTAVE SINGKAT* ${ }^{*} \quad 55$ 


\section{PRAKATA}

Buku cilik (buklik)/buklet ini, merupakan sebuah tutorial bagaimana mengimplementasikan metode elemen hingga berdasarkan metode Galerkin untuk menyelesaikan persamaan Helmholtz, atau lebih dikenal sebagai Metode Elemen Hingga Ranah Frekuensi. Persamaan Helmholtz merupakan model dari persamaan gelombang skalar, yang muncul dari sejumlah fenomena fisis. Misalnya dalam Elektromagnetika untuk memperoleh informasi perilaku pandu gelombang (waveguide), persamaan Helmholtz perlu diselesaikan secara numerik, mengingat bentuk geometrik bahan penyusun menyebabkan solusi analitik sulit didapat. Persamaan gelombang skalar untuk pandu gelombang isotropik homogen digunakan untuk memperkenalkan metode elemen hingga (MEH). Untuk lebih sederhananya, digunakan elemen segitiga orde pertama.

Tulisan ini menunjukkan bagaimana pengetahuan tentang metode elemen hingga (Finite Element Method, FEM) dapat dipelajari dalam waktu singkat dengan menggunakan MATLAB/OCTAVE. Hal ini menunjukkan bagaimana pengetahuan yang diperoleh dapat diperluas untuk masalah elektromagnetik lainnya.

Berbagai studi kasus diberikan sebagai latihan. Studi kasus yang diberikan, berasal dari bidang yang berkaitan dengan aplikasi fisika terkait bidang hayati yang menjadi misi utama yang diemban penulis. Bahkan beberapa studi kasus dirancang agar dapat digunakan untuk membantu penelitian mahasiswa S1/S2/S3, serta untuk penelitian yang sifatnya garda depan (research frontier) dalam bidang Komputasi Fisika, Komputasi Matematika, maupun Komputasi Elektromagnetika.

Terima kasih kepada saudara Teguh Pujanegara, atas bantuannya menyadur rutin distmesh. Juga kepada Dr. Diah Chaerani, dari Universitas Padjadjaran atas masukannya.

Penulisan buklik ini merupakan output skim Penelitian Strategis Unggulan, hibah DIPA-IPB, 0558/023-04.2.01/12/2012, yang didanai oleh Kementrian Pendidikan dan Kebudayaan, Republik Indonesia, dengan kontrak no : 44/I3.24.4/SPK-PUS/IPB/2012. Juga merupakan output hasil penelitian kerjasama lintas disiplin dalam bingkai Research Cluster for Dynamics and Complex System di FMIPA-Institut Pertanian Bogor. 
Buklik ini merupakan buku kedua dari seri : PERSAMAAN DIFERENSIAL PARSIAL, ANALITIK DAN METODE ELEMEN HINGGA, SERTA APLIKASINYA.

BOGOR, 31 Agustus 2019 
Program Hibah Penulisan Buku

Tahun 2019

Direktorat Pengelolaan Kekayaan Intelektual

Direktorat Jenderal Penguatan Riset dan Pengembangan

Kementrian Riset, Teknologi Dan Pendidikan Tinggi

Republik Indonesia 


\section{PENDAHULUAN}

Buklik (buku cilik) ini, dapat dipandang sebagai sebuah tutorial bagaimana mengimplementasikan metode elemen hingga berdasarkan metode Galerkin untuk menyelesaikan persamaan Helmholtz, atau lebih dikenal sebagai Metode Elemen Hingga Ranah Frekuensi. Persamaan Helmholtz merupakan model dari persamaan gelombang skalar, yang muncul dari sejumlah fenomena fisis. Misalnya dalam Elektromagnetika untuk memperoleh informasi perilaku pandu gelombang (waveguide), persamaan Helmholtz perlu diselesaikan secara numerik, mengingat bentuk geometrik bahan penyusun menyebabkan solusi analitik sulit didapat. Persamaan gelombang skalar untuk waveguide isotropik homogen digunakan untuk memperkenalkan metode elemen hingga (MEH). Untuk lebih sederhananya, digunakan elemen segitiga orde pertama. Tulisan ini menunjukkan bagaimana pengetahuan tentang metode elemen hingga (Finite Element $\mathrm{Me}$ thod, FEM) dapat dipelajari dalam waktu singkat dengan menggunakan MATLAB/OCTAVE. Hal ini menunjukkan bagaimana pengetahuan yang diperoleh dapat diperluas untuk masalah elektromagnetik lainnya.

Berbagai studi kasus diberikan sebagai latihan. Bahkan beberapa studi kasus dirancang agar dapat digunakan untuk membantu penelitian mahasiswa S1/S2/S3, serta untuk penelitian yang sifatnya garda depan (research frontier) dalam Komputasi Fisika, Komputasi Matematika, maupun Komputasi Elektromagnetik. Studi kasus yang diberikan, berasal dari beberapa bidang yang berkaitan dengan aplikasi terkait bidang hayati yang menjadi misi utama keilmuan yang diemban penulis. 


\section{Bab 1}

\section{PERSAMAAN HELMHOLTZ}

4 Ketersediaan daya komputasi yang besar dan murah menggunakan komputer 5 desktop atau laptop menjadikan solusi numerik dari permasalahan elektromag6 netik menjadi hal yang layak, bahkan bagi mahasiswa sarjana sekalipun. Di ka7 langan pendidik telah diambil dua pendekatan: menggunakan perangkat lunak 8 yang tersedia secara komersial [16] (yang mungkin menjadi pilihan yang mahal), 9 atau desain antarmuka pengguna dan kode simulasi [21, 22] berdasarkan paket - matematis terprogram. Kedua pendekatan ini bukan merupakan obyek dari tulisan ini. Tujuan dari tulisan ini adalah memperkenalkan metode elemen hingga ranah frekuensi untuk persamaan Helmholtz melalui MATLAB/OCTAVE dan menyelesaikan permasalahan elektromagnetik. MATLAB telah digunakan di seluruh dunia dalam pengajaran banyak mata kuliah rekayasa, misalnya, pemrosesan sinyal dan teknik kontrol. Ini tidak akan mudah bagi para pengajar dalam bidang elektromagnetik untuk mengharapkan siswa untuk memiliki pengetahuan dan akses menggunakan MATLAB, alternatifnya dapat digunakan OCTAVE yang merupakan freeware yang menerima skrip MATLAB. Metode Elemen Hingga (FEM) adalah teknik yang relatif mapan dalam elektromagnetik dan masih merupakan area penelitian yang cukup aktif. Hal ini didukung oleh beberapa buku teks dan monograf yang cukup baik tersedia. Tetapi, bahan tersebut hanya cocok bagi para peneliti atau untuk perkuliahan khusus. Selain itu, buku teks tersebut sangat menekankan dasar matematika yang ketat dari berbagai formulasi berbagai FEM. Sebuah pendekatan praktis untuk penurunan dari FEM dan pelaksanaannya diberikan pada pustaka [14]. Pada tulisan ini diberikan uraian FEM yang singkat dan mudah dipahami melalui MATLAB, mengingat MATLAB menyediakan fasilitas untuk operasi matriks dan alokasi memori yang dinamis. Materi utama terkait FEM dalam tulisan ini dapat dibahas dalam kuliah selama dua-empat jam. Mahasiswa mungkin diberikan kesempatan selama dua minggu untuk menyerap materi dan mengerjakan tugas berupa rangkaian tugas berdsarkan serangkaian latihan yang didaftarkan 
dalam tulisan ini. Perlu dicatat bahwa setidaknya satu paket perangkat lunak FEM komersial, yaitu FEMLAB dari COMSOL Inc, [10] memiliki versi sebagai add-on untuk MATLAB. Paket ini tidak cocok untuk mengajar pemrograman FEM. Namun, seperti yang digambarkan dalam rujukan [27], mahasiswa dapat menggunakan software ini untuk menguji formulasi variational yang diperoleh oleh mereka, mengingat perangkat lunak menerima bentuk formulasi variasional sebagai input. Dengan demikian, [27] dan tulisan ini saling melengkapi jika FEMLAB tersedia.

Buklik ini melengkapi komputasi Elektromagnetik berbahasa Indonesia untuk Metoda Beda Hingga Kawasan Waktu (Finite Difference Time Domain, FDTD) [25]) dan Metode Momen (Methods of Moment, MoM) yang populer di bidang antena [26].

\subsection{Persamaan Helmholtz dalam Elektro-Magnetik}

Pandu gelombang ( Waveguide) memainkan peranan penting dalam perambatan gelombang ber-frekuensi tinggi. Secara umum, pemodelan waveguide dimulai dari persamaan Maxwell kemudian menjadi persamaan Helmholtz. Dengan kata lain, dasar analisa perambatan gelombang di waveguide secara umum adalah persamaan Maxwell. Dengan menggunakan hukum Ampere dan hukum Faraday akan dijelaskan penurunan persamaan Maxwell.

Pada tahun 1820 Ampere telah menurunkan hubungan arus listrik dan medan magnet dalam bentuk persamaan matematika. Hukum integral keliling Ampere menyatakan bahwa bila garis tertutup $C$ mengelilingi kabel lurus $I$ yang dialiri listrik, maka besaran integral tertutup sepanjang garis tertutup $C$ untuk medan magnet $H$ yang ditimbulkan oleh $I$ adalah sama dengan besarnya arus listrik tersebut. Integral tertutup medan listrik dinyatakan sebagai jumlah keseluruhan garis tertutup $C$ yang terbagi pada bagian kecil $d l$ dikalikan dengan medan listrik sejajar $d l$.

$$
\oint_{C} H \bullet d l=I .
$$

Misalkan $J$ menyatakan kepadatan arus listrik pada tiap satuan unit arus listrik dan arus listrik tersebut menembus penampang $S$. Asumsikan bahwa penampang tersebut bukan dalam batang tetapi penampang yang terhingga. Penampang tersebut memiliki vektor normal $n$ dan memiliki keliling $C$. Komponen arus listrik yang melalui penampang $S$ secara tegak lurus dinyatakan oleh $J \bullet n$. Dengan mengintegralkan permukaan penampang $S$ diperoleh keseluruhan arus listrik pada penampang $S$. Oleh karena itu bagian kanan pada persamaan (1.1) dapat ditulis

$$
\oint_{C} H \bullet d l=\int_{S} J \bullet n d S .
$$


Pada tahun 1831 Faraday membuktikan fenomena perubahan medan magnet yang menimbulkan arus listrik. Hukum Faraday menyatakan bahwa perubahan medan listrik mengakibatkan tegangan di sepanjang loop tertutup $C$. Pada saat induksi magnet $B$ yang menembus loop tertutup $C$ berubah maka besaran tersebut sama dengan berkurangnya tegangan sesuai dengan perubahan waktu di loop tertutup $C$ tersebut. Fenomena ini dapat dinyatakan oleh

$$
\oint_{C} E \bullet d l=-\frac{\partial}{\partial t} \int_{S} B \bullet n d S .
$$

Hukum integral keliling Ampere dan hukum Faraday dapat digabungkan dengan menggunakan perubahan listrik. Rasio perubahan waktu terhadap perubahan listrik $D$ disebut sebagai perubahan arus listrik yang sama dengan arus listrik dalam hukum Ampere. Akibatnya persamaan (1.2) menjadi

$$
\oint_{C} H \bullet d l=\int_{S} J \bullet n d S+\frac{\partial}{\partial t} \int_{S} D \bullet n d S .
$$

Hukum integral keliling Ampere ini dapat digabungkan dengan hukum Faraday dan persamaan tersebut merupakan persamaan dasar Maxwell. Dengan menggunakan teori Stokes, ruas kiri pada persamaan (1.3) dan (1.4) dapat diubah menjadi integral permukaan. Permukaan yang diintegralkan harus diambil sekecil mungkin supaya berlaku di seluruh ruang. Akibatnya berlaku penurunan persamaan Maxwell berikut

$$
\begin{gathered}
\nabla \times H=J+\frac{\partial D}{\partial t} \\
\nabla \times E=-\frac{\partial B}{\partial t} .
\end{gathered}
$$

Dalam hukum dasar elektromagnet nilai muatan listrik sama dengan jumlah perubahan listrik yang ditimbulkannya dan dikenal sebagai hukum Gauss untuk perubahan listrik. Hukum Gauss yang lain yang berhubungan dengan perubahan listrik yaitu tidak ada fenomena muatan listrik yang hanya mempunyai satu kutub saja. Kedua fenomena di atas dapat digambarkan oleh persamaan di bawah ini

$$
\begin{aligned}
& \nabla \bullet D=\rho \\
& \nabla \bullet B=0 .
\end{aligned}
$$

Persamaan (1.5) hingga 1.8) memuat banyak variabel diantaranya variabel medan listrik $E$, perubahan listrik $D$, medan listrik $H$ dan induksi magnet $B$. Untuk mendapatkan medan listrik dan medan magnet akan dilakukan penurunan pada persamaan-persamaan tersebut.

Suatu medium berdielektrik yang homogen digambarkan di seluruh ruang analisa dengan permitivitas $\varepsilon$ dan permeabilitas $\mu$. Pada medium homogen, 
perubahan listrik dan induksi magnet dapat dinyatakan sebagai $D=\varepsilon E$ dan $B=\mu H$. Dengan mensubstitusikan kedua persamaan ini pada persamaan dasar Maxwell maka diperoleh persamaan medan listrik dan medan magnet. Untuk mendapatkan persamaan medan listrik dilakukan penghapusan medan magnet pada persamaan Maxwell dengan menggunakan operasi putaran pada persamaan (1.6) sehingga diperoleh

$$
\nabla \times \nabla \times E+\mu \frac{\partial}{\partial t}(\nabla \times H)=0 .
$$

Dengan menggunakan hubungan $\nabla \bullet E=\rho / \varepsilon$ dan $\nabla \times \nabla \times A=\nabla(\nabla \bullet A)-\nabla^{2} A$ maka persamaan (1.9) menjadi

$$
\nabla \frac{\rho}{\varepsilon}-\nabla^{2} E+\mu \frac{\partial J}{\partial t}+\varepsilon \mu \frac{\partial^{2} E}{\partial t^{2}}=0 .
$$

Dengan menggunakan operasi putaran pada persamaan (1.5) kemudian disubstitusikan pada persamaan (1.6) untuk menghilangkan medan listrik dari persamaan Maxwell maka diperoleh persamaan di bawah ini.

$$
-\nabla^{2} H-\nabla \times J+\varepsilon \mu \frac{\partial^{2} H}{\partial t^{2}}=0 .
$$

Medan listrik dan medan magnet dalam permasalahan elektromagnet sebagian besar berubah sebagai persamaan sinus dengan frekuensi angular $\omega$ pada setiap perubahan waktu, misalnya $e^{j \omega t}$. Akibatnya persamaan medan listrik dan medan magnet dapat ditulis sebagai berikut.

$$
\begin{gathered}
-\nabla^{2} E+l^{2} E=\nabla \frac{\rho}{\varepsilon}+j \omega \mu J \\
-\nabla^{2} H+l^{2} H=-\nabla \times J \\
l=\omega \sqrt{\varepsilon \mu}=\frac{2 \pi f}{v}=\frac{2 \pi}{\lambda} .
\end{gathered}
$$

Persamaan (1.12) dan (1.13) disebut sebagai persamaan Helmholtz dengan $l$ adalah tetapan hantar. Karena $1 / \sqrt{\varepsilon \mu}$ memiliki satuan kecepatan yang ditunjukkan oleh $v(\mathrm{~m} / \mathrm{s})$ sedangkan $f(H z)$ frekuensi dan kecepatan angular $\omega=$ $2 \pi f \cdot f / v$ mempunyai satuan panjang maka $\lambda$ disebut sebagai panjang gelombang.

Jika suatu medan listrik dan medang magnet di titik yang sangat jauh dari sumber gelombang maka keberadaan muatan listrik $\rho$ dan arus listrik $J$ sebagai sumber gelombang dapat tidak dianggap. Oleh karena itu diperoleh persamaan Helmholtz berikut.

$$
-\nabla^{2} E+l^{2} E=0
$$




$$
-\nabla^{2} H+l^{2} H=0 .
$$

Untuk mempelajari penggunaan FEM melalui MATLAB, pada pembahasan lebih lanjut digunakan persamaan Helmholtz berikut

$$
-\nabla^{2} u+k u=0,
$$

dengan $k<0, k=-l^{2}$ dan $u$ sebagai variabel medan listrik atau medan magnet.

Persamaan (1.17) menggambarkan gelombang datar yang merupakan gelombang ideal dimana gelombang elektromagnet ini terhantar di ruang bebas dengan kecepatan cahaya. Oleh karena itu, gelombang datar merupakan gelombang di lokasi tak terhingga dari sumber gelombang yang menimbulkannya. Pada saat gelombang datar terhantar di ruang yang homogen, amplitudo gelombang tidak akan berubah dan fasenya tidak mengalami ketidakkontinyuan. Tetapi pada saat gelombang datar melewati medium yang mempunyai tetapan medium yang berlainan maka komponen medan listrik dan medan magnet di perbatasan antar medium tersebut harus memenuhi syarat batas. Untuk kemudahan, kita perhatikan beberapa kasus berikut.

\section{Syarat Batas}

Ada 2 jenis syarat batas yang biasa digunakan pada moda Elektrik atau Magnetik apabila berada pada daerah yang terbatas, yaitu

- Syarat Batas: moda-TE

Untuk moda-TE, $u$ menyatakan medan magnetik aksial, $H_{z}$, dan syarat batas yang digunakan adalah syarat batas Neuman, $\partial u / \partial n=0$, dengan $n$ menyatakan arah normal di batas.

- Syarat Batas: moda-TM.

Untuk moda-TM, $u$ menyatakan medan elektrik aksial, $E_{z}$, dan syarat batas untuk batas konduktif sempurna yang harus dipenuhi adalah, $u=0$. Syarat ini, sering disebut juga sebagai syarat Dirichlet.

Sementara itu, apabila daerah tak terbatas, digunakan syarat Sommerfeld, yang tidak dibahas dalam buklik ini, tetapi bagaimana implementasi pemrogramannya diberikan sebagai bagian rangkaian latihan. 


\section{${ }_{150} \mathrm{Bab} 2$}

\section{"Metode Elemen Hingga "Ranah Frekuensi : Hampiran Galerkin}

Untuk mendapatkan hampiran elemen hingga, dapat dilakukan dengan 2 cara, yaitu dengan cara meminimumkan energi yang dikenal dengan Metode Rayleigh-Ritz, dan metode hampiran proyeksi di ruang fungsi yang juga dikenal dengan Metode Galerkin.

a. Metode Rayleigh-Ritz

FEM memecahkan persamaan (1.17) dengan meminimumkan fungsional energi yang diberikan oleh:

$$
J(u)=\frac{1}{2} \int_{\Omega}(\nabla u \cdot \nabla u+k u u) d x .
$$

b. Metode Galerkin

FEM untuk memecahkan persamaan (1.17) dengan menyelesaikan bentuk lemah yang diberikan oleh:

$$
\begin{aligned}
b(u, v) & =f(v), \\
\operatorname{dengan} b(u, v) & =\int_{\Omega}(\nabla u \cdot \nabla v+k u v) d x, \\
f(v) & =\int f v d x,
\end{aligned}
$$


untuk sembarang fungsi $v$. Bentuk lemah ini, diperoleh dengan cara mengalikan persamaan (1.17) dengan fungsi test $v$, dan kemudian dilakukan aturan integrasi sebagaimana diberikan di Lampiran.

Dalam buklik ini, akan digunakan metode Galerkin untuk mendapatkan hampiran metode elemen hingga, mengingat konsep yang digunakan mudah difahami karena mempergunakan pendekatan ruang-vektor dan sifat-sifat di dalam ruang vektor. Persamaan bentuk lemah yang diperoleh melalui metode Galerkin ini, bisa juga diturunkan melalui metode Rayleigh-Ritz, yang tidak dibahas di sini karena memerlukan pengetahuan kalkulus variasi. Untuk banyak masalah fisika, pendekatan melalui metode Rayleigh-Ritz selalu menghasilkan bentuk lemah yang identik dengan metode Galerkin.

Dalam implementasi FEM berdasarkan metode Galerkin, ada 3 langkah utama yang dilakukan, yaitu:

1. Memilih basis dari ruang solusi.

2. Menuliskan solusi hampiran berdasarkan basis yang dipilih.

3. Solusi hampiran disubstitusikan ke bentuk lemah, atau diproyeksikan ke ruang solusi.

Dengan melalui serangkaian studi kasus berikut, Metoda Galerkin diaplikasikan untuk mendapatkan solusi persamaan Helmholtz sebagai Metode Elemen Hingga ranah frekuensi.

Kasus 1

Perhatikan persamaan Helmholtz dengan syarat batas Dirichlet berikut

$$
\begin{aligned}
-\nabla^{2} u+k u & =0 & & \text { di } \Omega \\
u & =g & & \text { di } \partial \Omega
\end{aligned}
$$

dimana $k$ dan $g$ adalah sembarang fungsi yang diketahui. Hal ini dapat diilustrasikan untuk gelombang datar yang melewati medium kedua yang merupakan penghantar sempurna.

Misalkan $\Omega=[0,1] \times[0,1]$ dan syarat batas $\partial \Omega$ yang diilustrasikan pada Gambar 2.1.

\section{Kasus 2}

Hal lain yang mungkin jika gelombang datar tersebut mengalami perubahan setelah melewati medium kedua. Perhatikan persamaan Helmholtz dengan syarat batas Dirichlet dan Neumann berikut

$$
\begin{aligned}
& -\nabla \cdot \nabla u+k u=0 \quad \text { di } \Omega \\
& u=p \quad \text { di } L_{1} \\
& n \cdot \nabla u=q \quad \text { di } L_{2}
\end{aligned}
$$






Gambar 2.1: Daerah $\Omega$

dimana $k, p$ dan $q$ adalah fungsi-fungsi yang diketahui. Misalkan $\Omega=[0,1] \times[0,1]$ dengan syarat batas Dirichlet di $L_{1}$ dan syarat batas Neumann di $L_{2}$.

Untuk menyelesaikan secara numerik kasus yang diuraikan di atas, akan digunakan FEM dengan teknik hampiran Galerkin. Implementasi untuk kedua kasus ini akan diuraikan secara bertahap dengan menggunakan MATLAB.

\section{Kasus 1}

Misal $v \in \mathcal{H}^{1}$ dimana $\mathcal{H}^{1}$ adalah himpunan dimana elemennya terdiri dari fungsi yang terturunkan, selain fungsinya yang apabila integral kwadratnya hingga, begitu juga turunannya. Atau dikenal juga dengan fungsi dengan energi yang hingga.

Dengan mengalikan persamaan Helmholtz pada kasus 1 dengan $v$ dan dilakukan integrasi bagian (integration by parts, lihat Lampiran), akan diperoleh:

$$
\int_{\Omega}(\nabla u \cdot \nabla v+k u v) d x=0 .
$$

Bentuk di atas, disebut bentuk lemah dari kasus 1.

Misal $V_{h} \in \mathcal{H}^{1}$ adalah ruang dari semua fungsi piecewise linear yang kontinu dalam sebuah partisi $K=\left\{T_{1}, T_{2}, \cdots, T_{N}\right\}$ dari $\Omega$ menjadi segitiga berukuran $\left|T_{i}\right|$. Himpunan fungsi tenda hat function didefinisikan $\left\{\varphi_{i}\right\}_{i=1}^{N}$ dimana $N$ menyatakan banyaknya node dalam partisi $\left\{T_{i}\right\}_{i=1}^{N}$ yang merupakan basis untuk $V_{h}$. Hampiran elemen hingga (finite element approximation) dari bentuk lemah (weak form) persamaan (2.3) adalah $u_{h} \in V_{h}$ sedemikian sehingga

$$
\int_{\Omega}\left(\nabla u_{h} \cdot \nabla v+k u_{h} v\right) d x=0, \text { untuk sembarang } v .
$$

Karena $u_{h} \in V_{h}$ maka $u_{h}$ dapat ditulis

$$
u_{h}=\sum_{j=1}^{N} z_{j} \varphi_{j},
$$




$$
\sum_{j=1}^{N} z_{j}\left(\int_{\Omega} \nabla \varphi_{j} \cdot \nabla \varphi_{i} d x+\int_{\Omega} k \varphi_{j} \varphi_{i} d x\right)=0, \text { untuk setiap } \phi_{i} \in\left\{\phi_{i}\right\}_{i=1}^{N}
$$

224 225

$$
\begin{gathered}
A_{i, j}=\int_{\Omega} \nabla \varphi_{j} \cdot \nabla \varphi_{i} d x+\int_{\Omega} k \varphi_{j} \varphi_{i} d x \\
b_{i}=0 \\
z=\left(z_{1}, z_{2}, \ldots, z_{N}\right)^{T} .
\end{gathered}
$$

$226 \quad$ Pada persamaan di atas $j$ bergerak sepanjang node dan $i$ bergerak sepanjang 227 node dengan nilai $u$ diketahui. Nilai $u$ pada $\partial \Omega$ yang diketahui dinotasikan ${ }_{228}$ dalam vektor $z_{e}$ dan nilai $u$ selainnya dinotasikan dalam $z_{n}$,

$$
\left(A_{e} \mid A_{n}\right)\left(\begin{array}{c}
z_{e} \\
z_{n}
\end{array}\right)=A_{e} z_{e}+A_{n} z_{n}=b
$$

matriks $A_{e}$ dihitung pada syarat batas. Sehingga solusi akhir $z_{n}$ dapat dihitung dengan sistem persamaan $A_{n} z_{n}=b-A_{e} z_{e}$ dimana $A_{n}$ sudah diketahui.

Misalkan daerah $\Omega$ dibagi menjadi enam $(N=6)$ elemen segitiga yang diperlihatkan pada gambar berikut ini

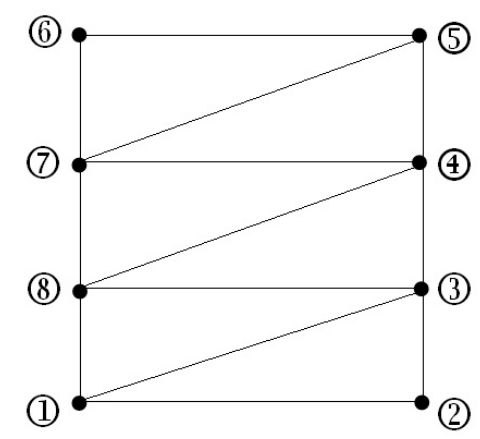

Gambar 2.2: Ilustrasi mesh (enam elemen segitiga) dalam $\Omega$ 
Misalkan koordinat dari setiap node diberikan pada tabel di bawah ini

Tabel 2.1: Nomor-nomor koordinat sebagai node

\begin{tabular}{|c|c|c|c|c|c|c|c|c|}
\hline Node & 1 & 2 & 3 & 4 & 5 & 6 & 7 & 8 \\
\hline$x$ & 0 & 1 & 1 & 1 & 1 & 0 & 0 & 0 \\
\hline$y$ & 0 & 0 & $\frac{1}{3}$ & $\frac{2}{3}$ & 1 & 1 & $\frac{2}{3}$ & $\frac{2}{3}$ \\
\hline
\end{tabular}

MATLAB mampu membaca data dari file yang diberikan dalam format ascii dengan file .dat, sehingga dalam MATLAB kita dapat menyimpan data koordinat untuk setiap node dengan pemrograman sebagai berikut.

node $1=\left[\begin{array}{lll}1 & 0 & 0\end{array}\right.$

$210 ;$

$311 / 3$;

$412 / 3$;

$511 ;$

$\begin{array}{lll}6 & 0 & 1 ;\end{array}$

$\begin{array}{lll}7 & 0 & 2 / 3 ;\end{array}$

8 r $1 / 3]$;

dlmwrite('koordinat1.dat', node1,',')

type koordinat 1 .dat

Pada Tabel 2.2 diberikan elemen-elemen yang berpadanan dengan node-node pada Tabel 2.1

Tabel 2.2: Nomor-nomor elemen segitiga

\begin{tabular}{|l|l|l|l|l|l|l|}
\hline Elemen & 1 & 2 & 3 & 4 & 5 & 6 \\
\hline Node 1 & 7 & 7 & 8 & 8 & 1 & 1 \\
\hline Node 2 & 5 & 4 & 4 & 3 & 3 & 2 \\
\hline Node 3 & 6 & 5 & 7 & 4 & 8 & 3 \\
\hline
\end{tabular}

Dengan menggunakan MATLAB kita dapat menyimpan data elemen-elemen di atas dengan pemrograman berikut.

segitiga1=[1 $7 \begin{array}{lll} & 5 & 6\end{array}$

2745 ;

$\begin{array}{lllll}3 & 8 & 4 & 7\end{array}$

$483 \quad 4$;

513 ; ;

$\left.\begin{array}{llll}6 & 1 & 2 & 3\end{array}\right]$;

dlmwrite('elemen1.dat', segitiga1,' ')

type elemen1.dat

Syarat batas untuk Gambar 2.1 diperlihatkan pada tabel berikut.

deltaomega $=\left[\begin{array}{lll}1 & 1 & 2\end{array}\right.$ 
Tabel 2.3: Nomor-nomor edge dengan syarat batas

\begin{tabular}{|c|c|c|c|c|c|c|c|c|}
\hline Edge & 1 & 2 & 3 & 4 & 5 & 6 & 7 & 8 \\
\hline Node 1 & 1 & 2 & 3 & 4 & 5 & 6 & 7 & 8 \\
\hline Node 2 & 2 & 3 & 4 & 5 & 6 & 7 & 8 & 1 \\
\hline
\end{tabular}

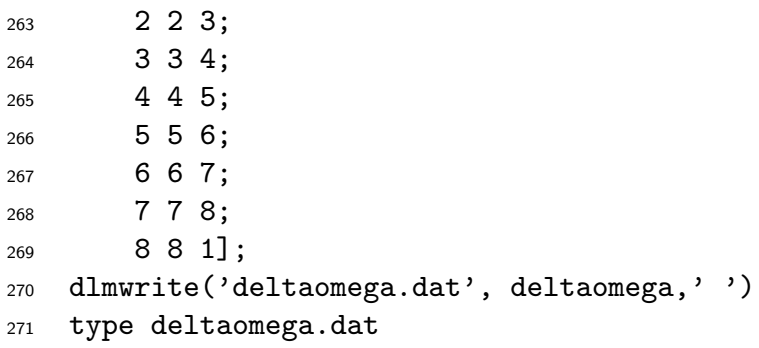

\section{Menyusun matriks stiffness}

Perhatikan bahwa untuk sebuah elemen segitiga $T$ misalkan $\left(x_{1}, y_{1}\right),\left(x_{2}, y_{2}\right)$, dan $\left(x_{3}, y_{3}\right)$ adalah titik-titik verteks dan $\varphi_{1}, \varphi_{2}$ dan $\varphi_{3}$ adalah fungsi basis yang berkorespondensi di $K$, yaitu

$$
\varphi_{i}\left(x_{j}, y_{j}\right)=\delta_{i j}, \quad i, j=1,2,3 .
$$

Oleh karena itu, diperoleh

$$
\varphi_{i}(x, y)=\frac{\operatorname{det}\left(\begin{array}{ccc}
1 & x & y \\
1 & x_{i+1} & y_{i+1} \\
1 & x_{i+2} & y_{i+2}
\end{array}\right)}{\operatorname{det}\left(\begin{array}{ccc}
1 & x_{i} & y_{i} \\
1 & x_{i+1} & y_{i+1} \\
1 & x_{i+2} & y_{i+2}
\end{array}\right)}
$$

277 dengan

$$
\nabla \varphi_{i}(x, y)=\frac{1}{2|T|}\left(\begin{array}{c}
y_{i+1}-y_{i+2} \\
x_{i+2}-x_{i+1}
\end{array}\right) .
$$

Matriks stiffness yang diperoleh adalah

$$
\begin{aligned}
M_{i j} & =\int_{T} \nabla \varphi_{i}\left(\nabla \varphi_{j}\right)^{T} d x d y \\
& =\frac{|T|}{(2|T|)^{2}}\left(\begin{array}{cc}
y_{i+1}-y_{i+2} & x_{i+2}-x_{i+1}
\end{array}\right)\left(\begin{array}{c}
y_{j+1}-y_{j+2} \\
x_{j+2}-x_{j+1}
\end{array}\right) .
\end{aligned}
$$


dengan indeks di dalam modulo 3. Bentuk sederhana persamaan di atas adalah

$$
M=\frac{|T|}{2} G G^{T},
$$

dimana

$$
G=\left(\begin{array}{ccc}
1 & 1 & 1 \\
x_{1} & x_{2} & x_{3} \\
y_{1} & y_{2} & y_{3}
\end{array}\right)^{-1}\left(\begin{array}{ll}
0 & 0 \\
1 & 0 \\
0 & 1
\end{array}\right)
$$

Pemrograman dalam MATLAB untuk menyusun matriks stiffness dapat kita tuliskan sebagai berikut.

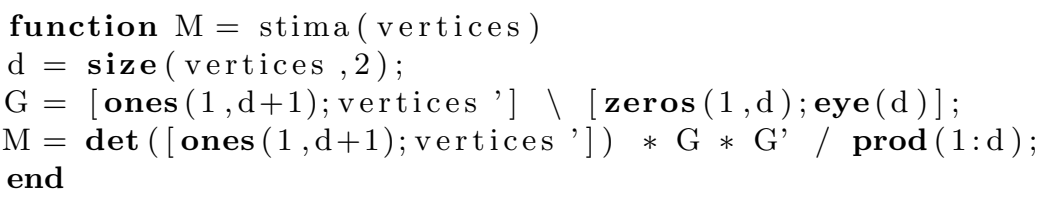

\section{Menyusun matriks massa}

Perhatikan bahwa

$$
B_{i j}=\sum_{T \subset \Omega} \int_{T} \varphi_{i} \varphi_{j} k d x .
$$

Dengan cara yang hampir sama dalam menyusun matriks stiffness, diperoleh matriks massa

$$
\int_{T} \varphi_{i} \varphi_{j} k d x=\frac{1}{24} \operatorname{det}\left(\begin{array}{cc}
x_{2}-x_{1} & x_{3}-x_{1} \\
y_{2}-y_{1} & y_{3}-y_{1}
\end{array}\right)\left(\begin{array}{ccc}
2 & 1 & 1 \\
1 & 2 & 1 \\
1 & 1 & 2
\end{array}\right) k\left(x_{s}, y_{s}\right)
$$

dimana $\left(x_{s}, y_{s}\right)$ adalah titik tengah pada segitiga $T$.

Untuk $k=0$, dengan menggunakan MATLAB diperoleh solusi dalam bentuk grafik berikut ini.

Solusi analitik pada kasus 1 untuk $k=0$ adalah $u=0$ mempunyai kesimpulan yang sama dengan solusi numerik yang ditampilkan pada Gambar 2.3.

function $\mathrm{k}=\mathrm{k} 0(\mathrm{x}, \mathrm{y})$;

$\mathrm{k}=0$

end

function SyaratBatas $=\operatorname{deltaO}(\mathrm{x})$

SyaratBatas $=\operatorname{zeros}(\operatorname{size}(\mathrm{x}, 1), 1)$

end

Pemrograman dengan MATLAB untuk kasus 1 sebagai berikut

load koordinat1.dat; koordinat1 $(:, 1)=[] ; \%$ koordinat simpul

load elemen1.dat; elemen $1(:, 1)=[] ; \%$ elemen hingga segitiga 


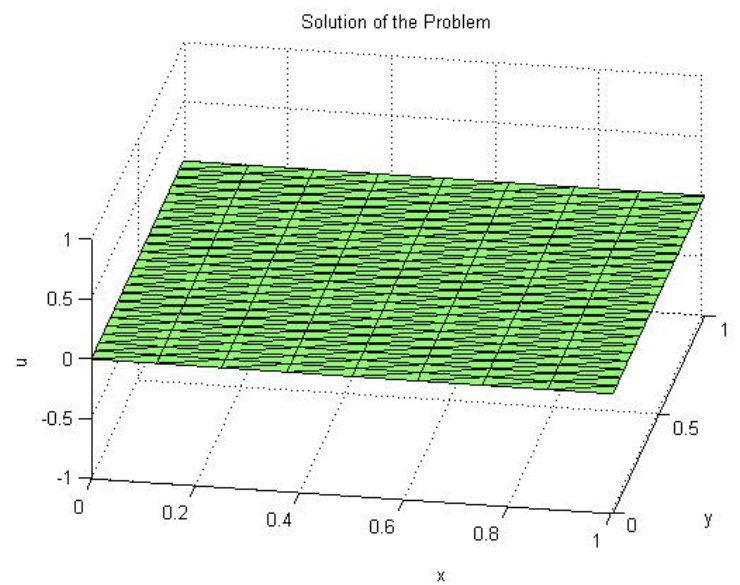

Gambar 2.3: Solusi kasus 1 untuk $k=0$.

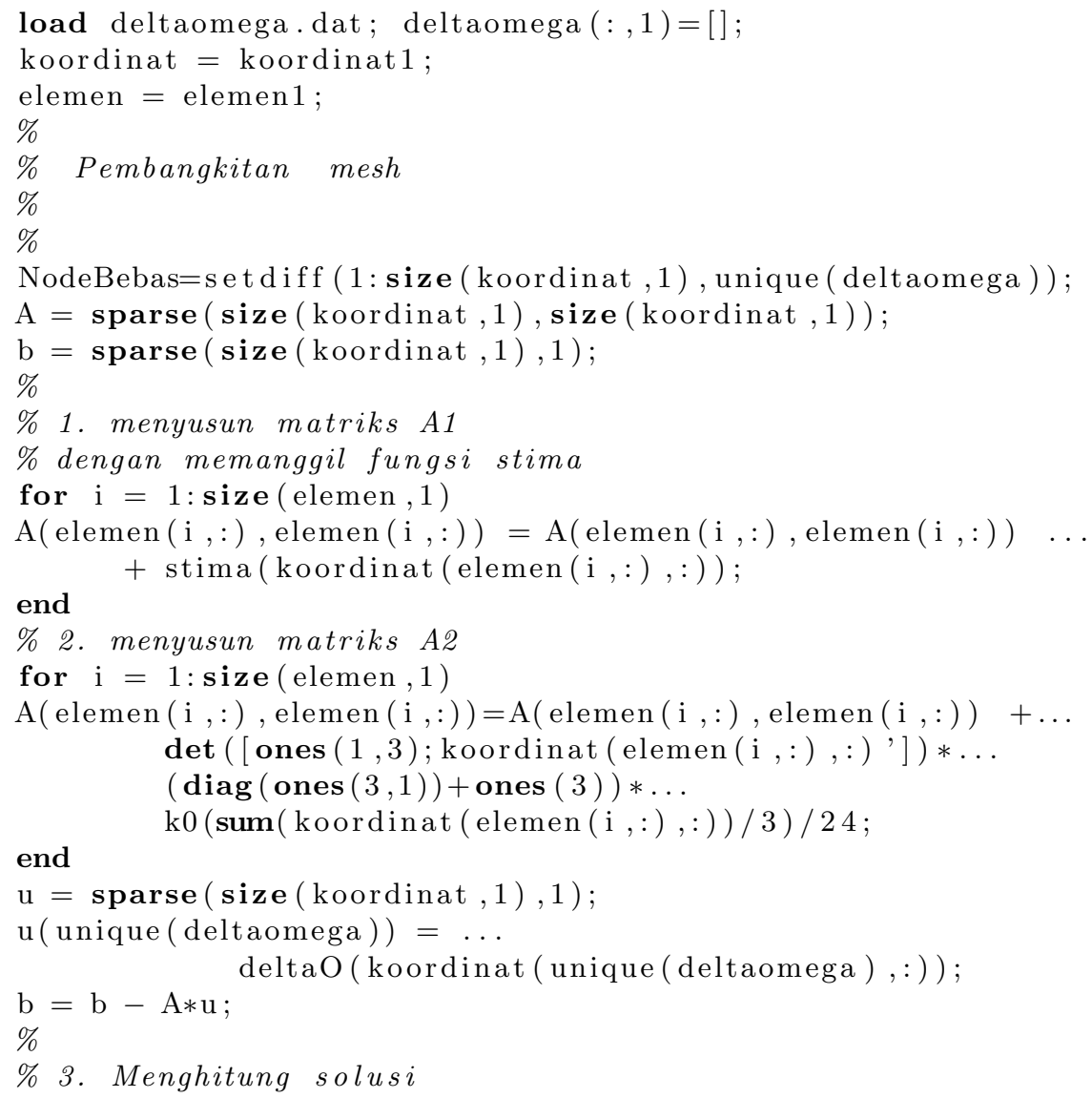




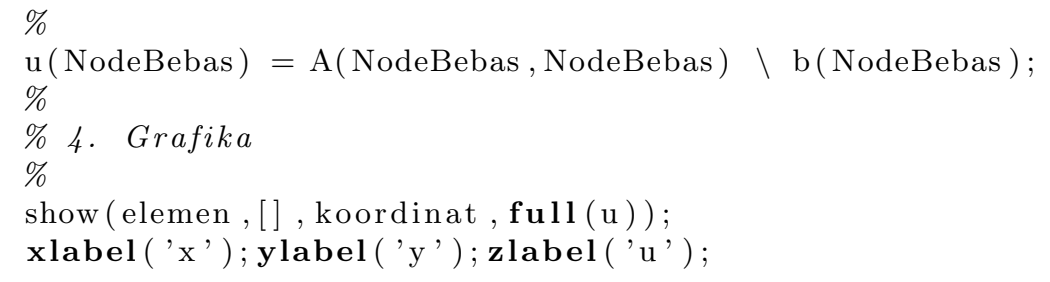

Kasus 2

Bentuk lemah untuk kasus 2 adalah

$$
\int_{\Omega}(\nabla u \cdot \nabla v+k u v) d x=\int_{L_{2}} q v d s .
$$

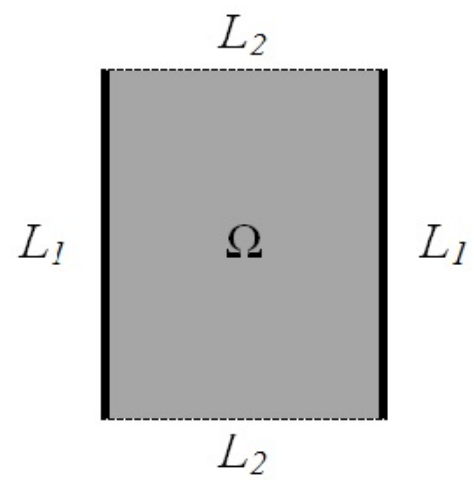

Gambar 2.4: Syarat batas untuk kasus 2a 


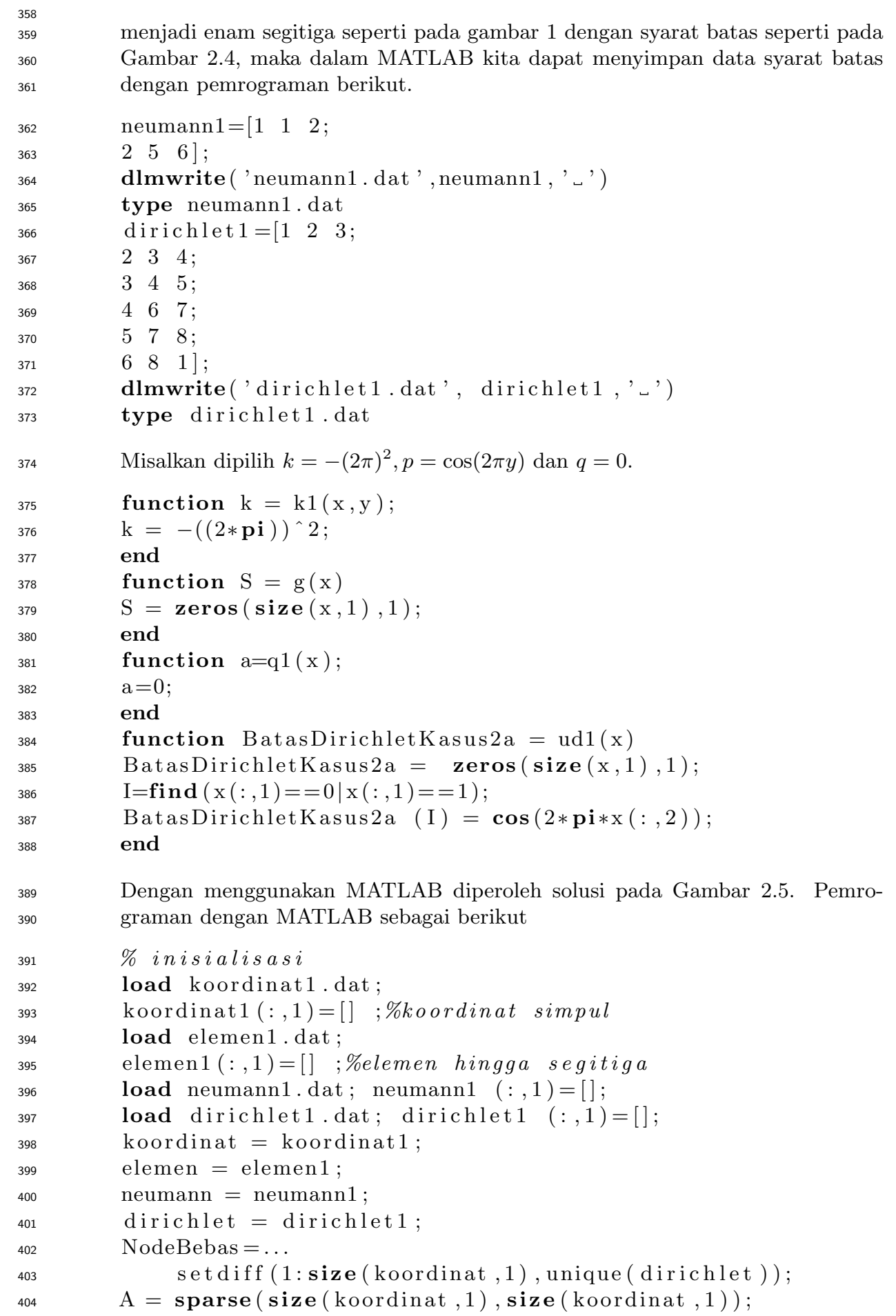




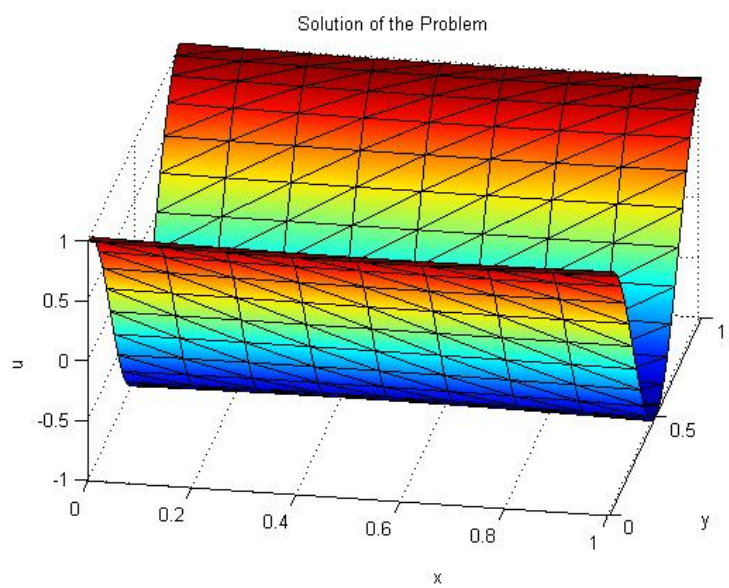

Gambar 2.5: Grafik permukaan solusi kasus 2a. Program lengkap ada di Lampiran 2.

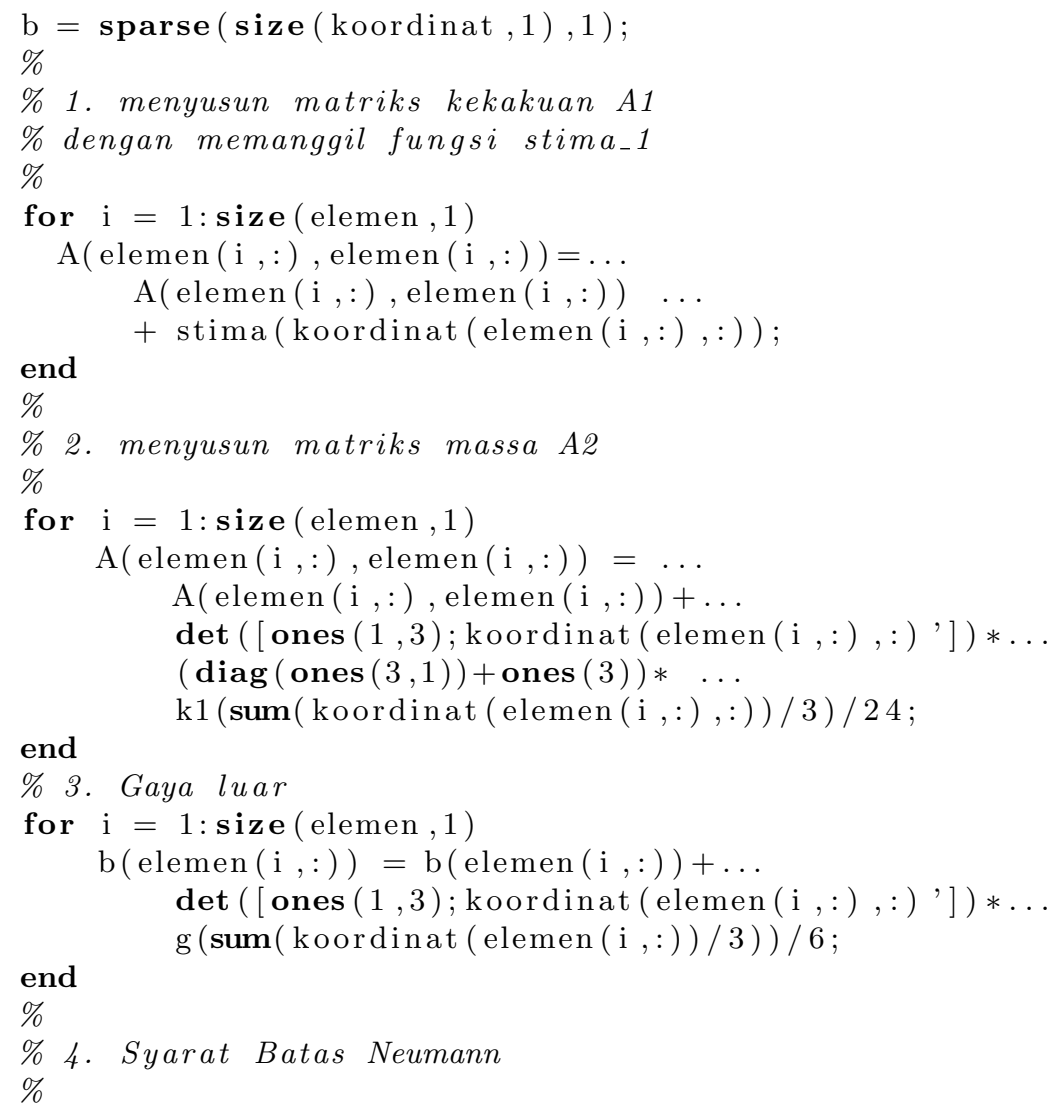




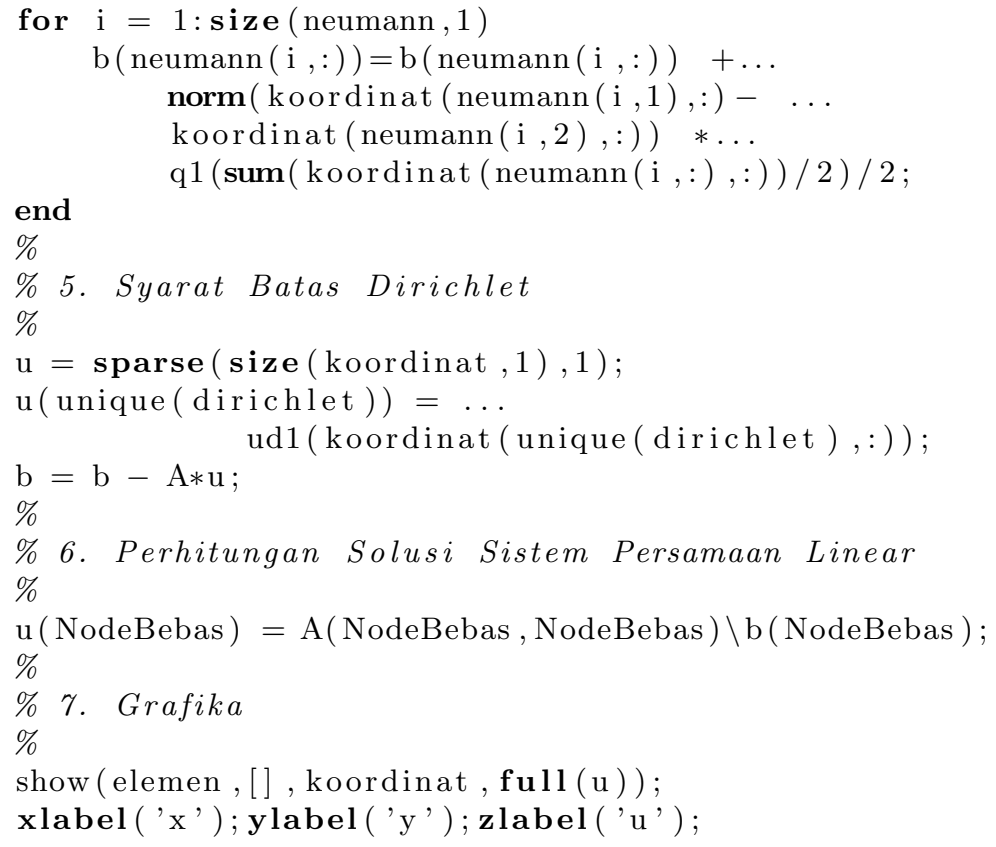

b (Kasus 2b) Misalkan daerah $\Omega$ dibagi menjadi empat $(N=4)$ elemen segitiga yang diperlihatkan pada gambar berikut ini Dengan nomor-nomor node, elemen

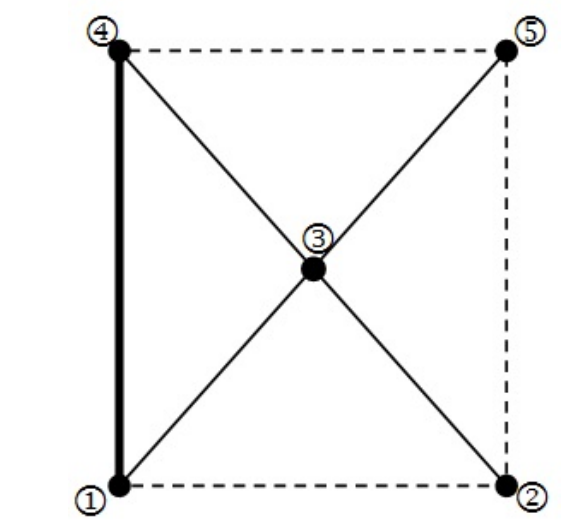

Gambar 2.6: Daerah $\Omega$ dibagi menjadi empat segitiga

457

\section{Gambar 2.6: Daerah $\Omega$ dibagi menjadi empat segitiga}

segitiga dan edge syarat batas pada tabel berikut: Misalkan $k=-(2 \pi)^{2}, p=$ $\cos (2 \pi y)$ dan $q=0$, dengan menggunakan MATLAB, diperoleh solusi dalam bentuk grafik berikut ini: Pemrograman kasus $2 \mathrm{~b}$ dengan MATLAB sebagai berikut

load koordinat 2 .dat;\% koordinat node

koordinat $2(:, 1)=[]$

load elemen2.dat; $\%$ daftar elemen segitiga 
Tabel 2.4: Nomor-nomor node, elemen, dan edge syarat batas

\begin{tabular}{|c|c|c|c|c|}
\hline Nomor & $\begin{array}{c}\text { Node } \\
\text { Koordinat) }\end{array}$ & $\begin{array}{c}\text { Elemen } \\
\text { Segitiga }\end{array}$ & $\begin{array}{c}\text { Syarat Batas } \\
\text { Neumann }\end{array}$ & $\begin{array}{c}\text { Syarat batas } \\
\text { Dirichlet }\end{array}$ \\
\hline 1. & $(0,0)$ & $1-2-3$ & $1-2$ & $4-1$ \\
\hline 2. & $(1,0)$ & $1-3-4$ & $2-5$ & \\
\hline 3. & $(1 / 2,1 / 2)$ & $3-2-5$ & $5-4$ & \\
\hline 4. & $(0,1)$ & $3-5-4$ & & \\
\hline 5. & $(1,1)$ & & & \\
\hline
\end{tabular}

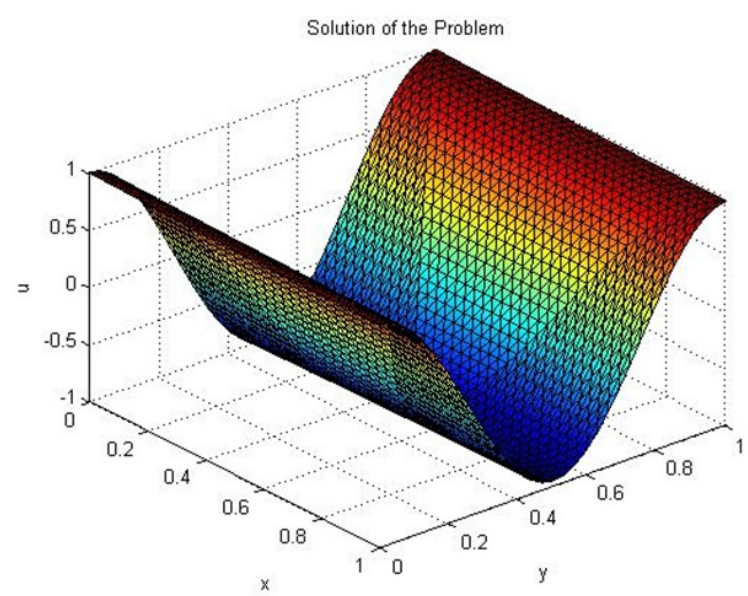

Gambar 2.7: Grafik permukaan solusi kasus 2b. Dihasilkan oleh program lengkap yang diberikan di Lampiran 2.

elemen $2(:, 1)=[]$;

load neumann3.dat; neumann3 $(:, 1)=[]$;

load dirichlet 3 .dat; dirichlet $3(:, 1)=[]$;

koordinat $=$ koordinat 2 ;

elemen=elemen 2 ;

neumann $=$ neumann 3 ;

dirichlet $=$ dirichlet 3 ;

NodeBebas $=$ setdiff $(1: \mathbf{s i z e}($ koordinat, 1$), \ldots$ unique (dirichlet));

$\mathrm{A}=\operatorname{sparse}(\mathbf{s i z e}(\operatorname{koordinat}, 1), \operatorname{size}($ koordinat, 1$))$;

$\mathrm{b}=\operatorname{sparse}(\operatorname{size}($ koordinat, 1$), 1)$;

$\%$ 1. menyusun matriks A1

\% dengan memanggil fungsi stima-1

for $\mathrm{i}=1: \mathbf{s i z e}($ elemen, 1$)$

$\mathrm{A}(\operatorname{elemen}(\mathrm{i},:)$, elemen $(\mathrm{i},:))=\ldots$ A(elemen $(\mathrm{i},:)$, elemen $(\mathrm{i},:)) \ldots$

$+\operatorname{stima}($ koordinat $(\operatorname{elemen}(\mathrm{i},:),:))$;

end 


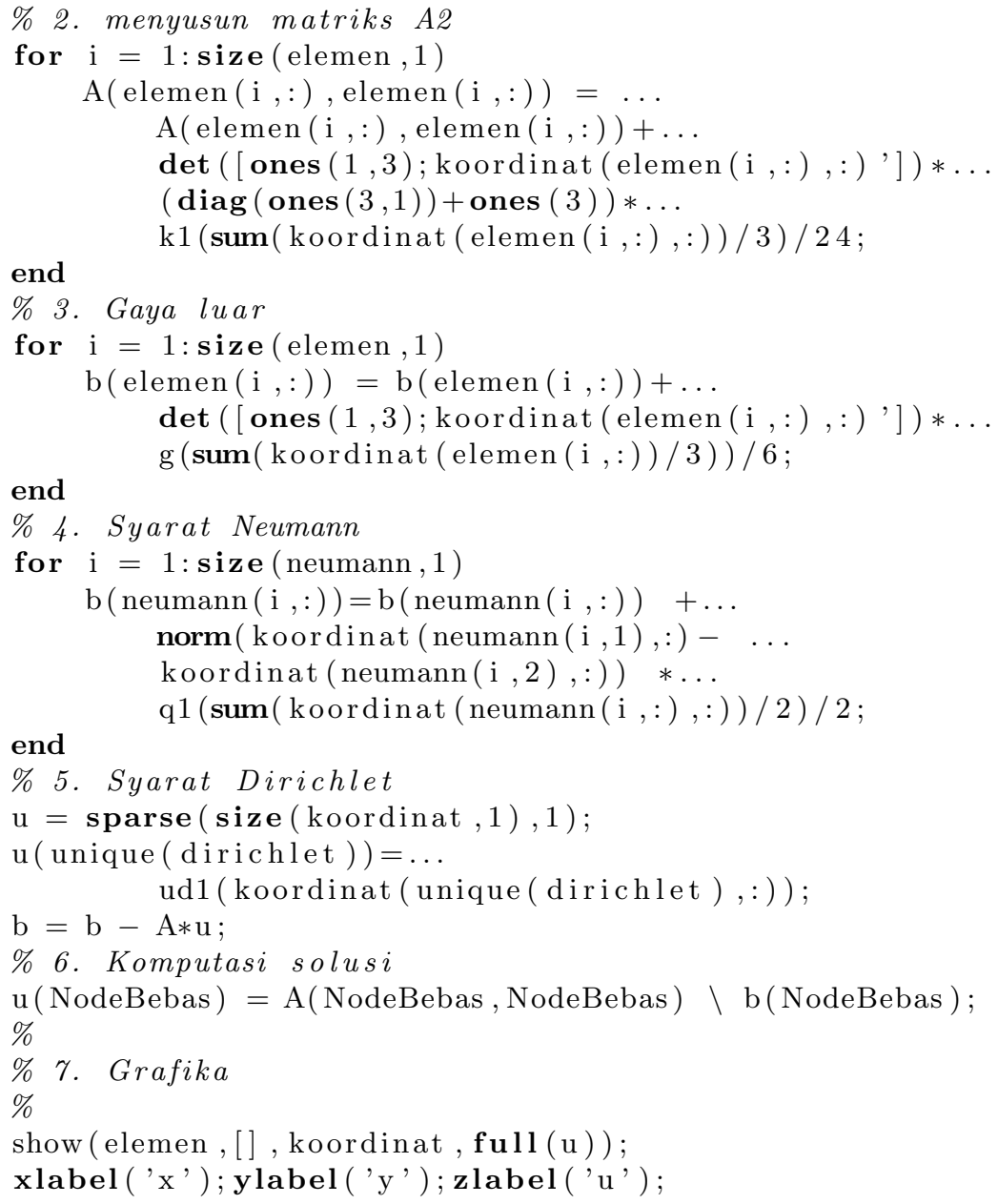

c (Kasus 2c) Misalkan daerah $\Omega$ dibagi menjadi delapan $(N=8)$ elemen segitiga yang diperlihatkan pada gambar berikut ini. Dengan nomor-nomor node, elemen segitiga dan edge syarat batas pada Tabel 2.5. Dengan fungsi $k$ yang melompat

$$
k=\left\{\begin{array}{ll}
1.5 & ; y>0.5 \\
1.4 & ; y \leq 0.5
\end{array},\right.
$$
dengan syarat Dirichlet yang diberikan oleh fungsi :

$$
p=\exp \left(\frac{-(y-0.5)^{2}}{0.4}\right),
$$

dan $q=0$.

$$
\begin{aligned}
& \text { function } \mathrm{k}=\mathrm{k} 3(\mathrm{x}) \\
& \text { if } \mathrm{x}(:, 2)<=0.5 \\
& \mathrm{k}=1.5 ; \\
& \text { else if } \mathrm{x}(:, 2)>0.5
\end{aligned}
$$




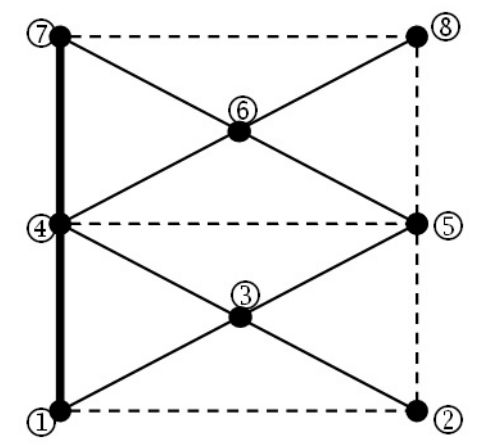

Gambar 2.8: Daerah $\Omega$ dibagi menjadi delapan segitiga

Tabel 2.5: Nomor-nomor node, elemen, dan edge syarat batas

\begin{tabular}{|c|c|c|c|c|}
\hline Nomor & $\begin{array}{c}\text { Node } \\
\text { Koordinat) }\end{array}$ & $\begin{array}{c}\text { Elemen } \\
\text { Segitiga }\end{array}$ & $\begin{array}{c}\text { Syarat Batas } \\
\text { Neumann }\end{array}$ & $\begin{array}{c}\text { Syarat batas } \\
\text { Dirichlet }\end{array}$ \\
\hline 1. & $(0,0)$ & $1-2-3$ & $1-2$ & $7-4$ \\
\hline 2. & $(1,0)$ & $1-3-4$ & $2-5$ & $4-1$ \\
\hline 3. & $(1 / 2,1 / 4)$ & $3-2-5$ & $5-8$ & \\
\hline 4. & $(0,1 / 2)$ & $4-3-5$ & $8-7$ & \\
\hline 5. & $(1,1 / 2)$ & $4-5-6$ & & \\
\hline 6. & $(1 / 2,3 / 4)$ & $4-6-7$ & & \\
\hline 7. & $(0,1)$ & $6-5-8$ & & \\
\hline 8. & $(1,1)$ & $7-6-8$ & & \\
\hline
\end{tabular}

$\mathrm{k}=1.4$

end

end

end

function DirichletBoundaryValueCase $2 \mathrm{~d}=\mathrm{ud} 3(\mathrm{x})$

DirichletBoundaryValueCase $2 \mathrm{~d}=\operatorname{zeros}(\operatorname{size}(\mathrm{x}, 1), 1)$;

$\mathrm{I}=$ find $(\mathrm{x}(:, 1)==0)$;

DirichletBoundaryValueCase $2 \mathrm{~d}(\mathrm{I})=\ldots$

$\exp \left(\left(-(\mathrm{x}(\mathrm{I}, 2)-0.5) \cdot{ }^{\wedge} 2\right) \cdot / 0.4\right) ;$

end

Dengan menggunakan MATLAB, diperoleh solusi dalam bentuk grafik berikut ini:

Pemrograman untuk kasus 3 dengan MATLAB sebagai berikut

load koordinat3.dat; \% koordinat simpul

koordinat $3(:, 1)=[]$;

load elemen 3 .dat; \% elemen hingga segitiga

elemen3 $(:, 1)=[]$;

load neumann4.dat; neumann $4(:, 1)=[]$; 


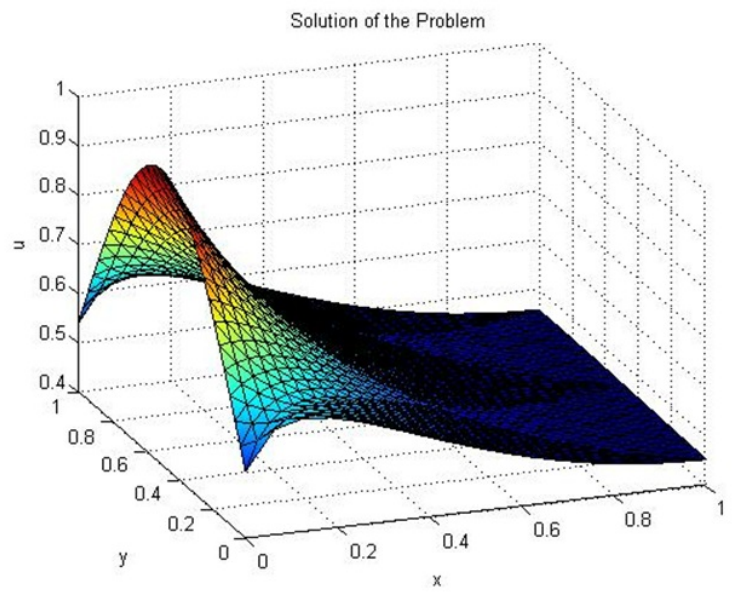

Gambar 2.9: Grafik permukaan solusi kasus 2c. Dihasilkan oleh program lengkap di Lampiran 2.

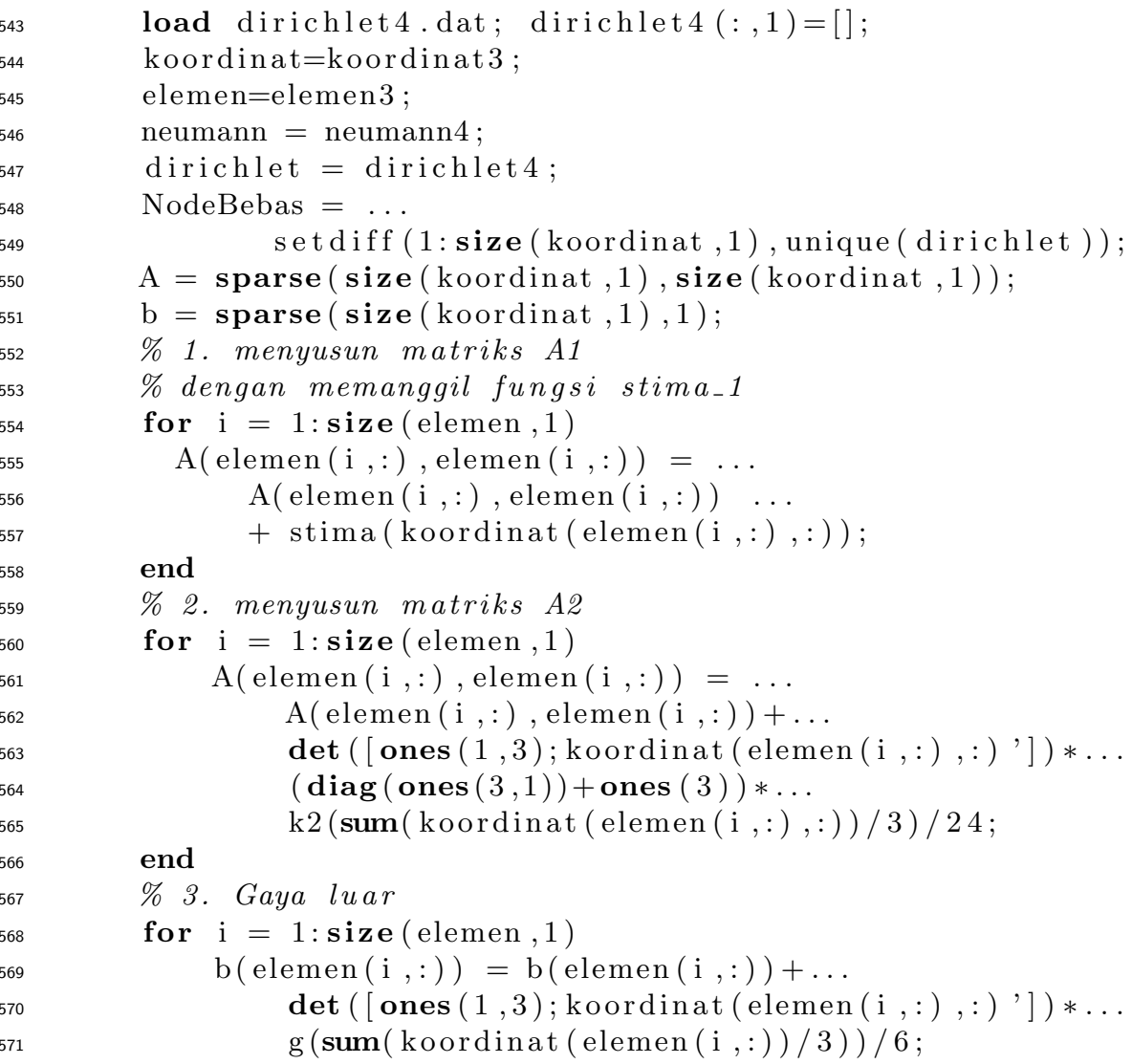


end

$\%$ 4. Syarat Neumann

for $\mathrm{i}=1: \operatorname{size}($ neumann, 1$)$

$\mathrm{b}(\operatorname{neumann}(\mathrm{i},:))=\mathrm{b}(\operatorname{neumann}(\mathrm{i},:))+\ldots$

$\operatorname{norm}($ koordinat $($ neumann $(\mathrm{i}, 1),:)-\ldots$

koordinat (neumann (i , 2),: )) *..

end

q1 (sum(koordinat (neumann $(\mathrm{i},:),:$ ) ) / 2) / 2 ;

\% 5. Syarat Dirichlet

$\mathrm{u}=\operatorname{sparse}(\mathbf{s i z e}($ koordinat, 1$), 1)$;

$\mathrm{u}($ unique $($ dirichlet $))=\ldots$ ud3 (koordinat (unique (dirichlet) , : )) ;

$\mathrm{b}=\mathrm{b}-\mathrm{A} * \mathrm{u}$;

$\%$ 6. Komputasi solusi

$\mathrm{u}($ NodeBebas $)=\mathrm{A}($ NodeBebas, NodeBebas $) \backslash \mathrm{b}($ NodeBebas $) ;$

\% 7. Grafika

show (elemen, [], koordinat, full (u));

xlabel ('x'); ylabel ('y'); zlabel ('u');

d (Kasus 2d) Misalkan daerah $\Omega$ dibagi menjadi duabelas $(N=12)$ elemen segitiga yang diperlihatkan pada Gambar 2.10. Sedangkan nomor-nomor node, elemen

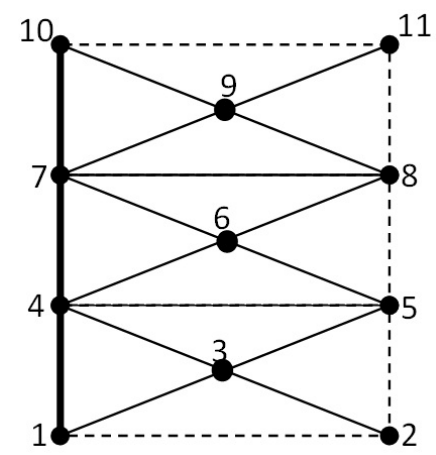

Gambar 2.10: Daerah $\Omega$ dibagi menjadi duabelas segitiga

segitiga dan node dengan syarat batas pada Tabel 2.6. Misalkan

$$
k= \begin{cases}1.4 & ; y>2 / 3 \text { atau } y<1 / 3 \\ 1.5 & ; 1 / 3 \leq y \leq 2 / 3\end{cases}
$$

sedangkan $p$ dan $q$ sama seperti pada kasus $2 c$.

function $\mathrm{k}=\mathrm{k} 4(\mathrm{x})$

if $(\mathrm{x}(:, 2)<1 / 3) \|(\mathrm{x}(:, 2)>2 / 3)$

$\mathrm{k}=1.4$;

else

$\mathrm{k}=1.5 ;$

end

end 
Tabel 2.6: Nomor node, elemen, dan edge syarat batas

\begin{tabular}{|c|c|c|c|c|}
\hline Nomor & $\begin{array}{c}\text { Node } \\
\text { (Koordinat) }\end{array}$ & $\begin{array}{c}\text { Elemen } \\
\text { Segitiga }\end{array}$ & $\begin{array}{c}\text { Syarat Batas } \\
\text { Neumann }\end{array}$ & $\begin{array}{c}\text { Syarat batas } \\
\text { Dirichlet }\end{array}$ \\
\hline 1. & $(0,0)$ & $1-2-3$ & $1-2$ & $10-7$ \\
\hline 2. & $(1,0)$ & $1-3-4$ & $2-5$ & $7-4$ \\
\hline 3. & $(1 / 2,1 / 6)$ & $3-2-5$ & $5-8$ & $4-1$ \\
\hline 4. & $(0,1 / 3)$ & $3-5-4$ & $8-11$ & \\
\hline 5. & $(1,1 / 3)$ & $4-5-6$ & $11-10$ & \\
\hline 6. & $(1 / 2,1 / 2)$ & $4-6-7$ & & \\
\hline 7. & $(0,2 / 3)$ & $6-5-8$ & & \\
\hline 8. & $(1,2 / 3)$ & $6-8-7$ & & \\
\hline 9. & $(1 / 2,5 / 6)$ & $7-8-9$ & & \\
\hline 10. & $(0,1)$ & $7-9-10$ & & \\
\hline 11. & $(1,1)$ & $9-8-11$ & & \\
\hline 12. & & $9-10-11$ & & \\
\hline
\end{tabular}

Dengan menggunakan MATLAB, diperoleh solusi dalam bentuk grafik sebagaimana diperlihatkan pada gambar berikut ini,

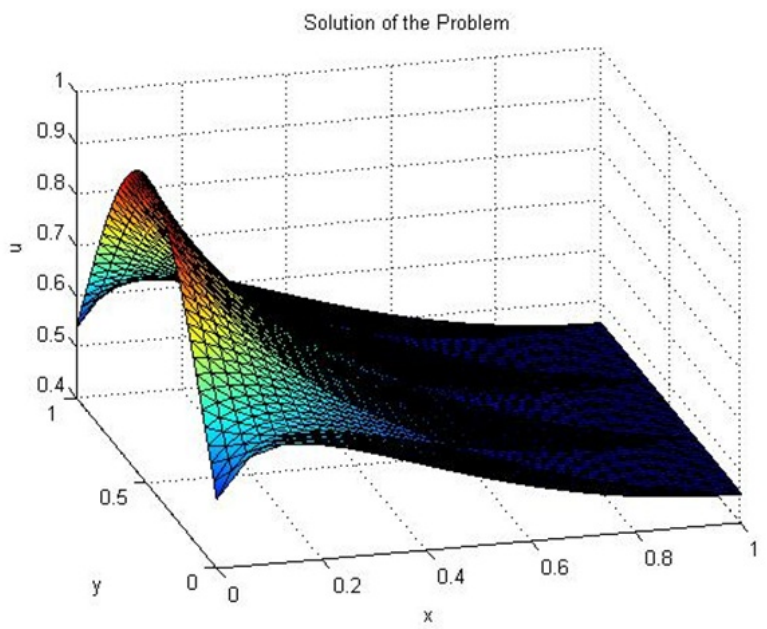

Gambar 2.11: Grafik permukaan solusi kasus 2d. Dihasilkan oleh program lengkap di Lampiran 2.

603

604

605

606

607

608

Pemrograman untuk kasus ini dengan MATLAB sebagai berikut

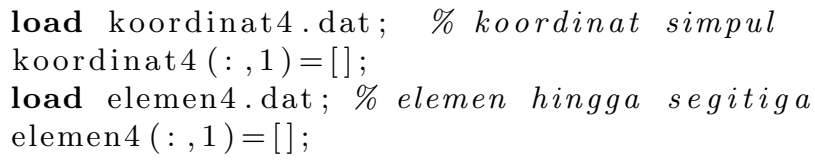


load neumann5.dat; neumann5 $(:, 1)=[]$;

load dirichlet5.dat; dirichlet $5(:, 1)=[]$;

koordinat $=$ koordinat 4 ;

elemen=elemenB4;

neumann = neumann5;

dirichlet $=$ dirichlet 5 ; $\%$

NodeBebas $=\ldots$ setdiff ( 1 : size (koordinat, 1$)$, unique (dirichlet)); 


\section{HISTORIANA}

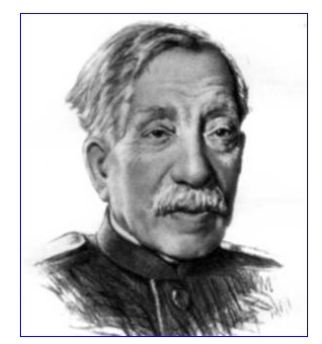

Gambar 2.12: Boris G. Galerkin (1871-1945), Seorang Insinyur Teknik Perkapalan Rusia, yang bekerja menggeluti bidang Mekanika Kontinua. Dari pengalamannya menggeluti PDP untuk pelat dan batang, lahir teknik penghampiran yang menjadi landasan Metode Elemen Hingga. (Sumber: Mac Tutor History of Mathematics Archive)



Gambar 2.13: Richard Courant (1832-1925), perintis teori Metode Elemen Hingga yang memformulasikan penyelesaian PDP numerik memanfaatkan partisi segi tiga (Triangular element) dan fungsi basis atas elemen untuk metode Galerkin. (Sumber: Mac Tutor History of Mathematics Archive) 


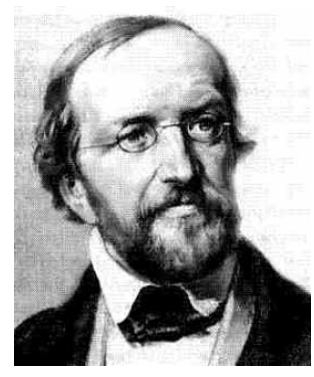

Gambar 2.14: Johann Peter Gustav Lejeune Dirichlet (1805-1859), perumus tipe syarat batas dalam persamaan differensial parsial. (Sumber: Mac Tutor History of Mathematics Archive)

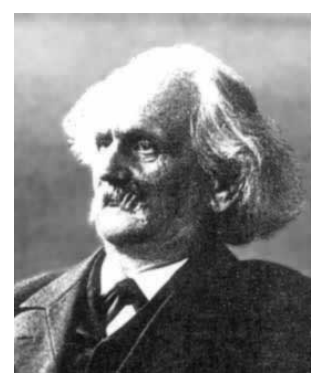

Gambar 2.15: Carl Friedrich Neumann (1888-1972), perumus tipe syarat batas dalam persamaan differensial parsial. (Sumber: Mac Tutor History of Mathematics Archive)

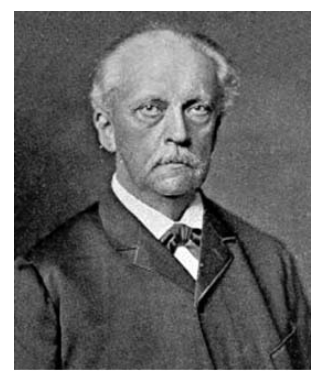

Gambar 2.16: Ferdinand Helmholtz (1821-1894), fisikawan perumus persamaan differensial parsial yang mendiskripsikan perambatan gelombang. (Sumber: Mac Tutor History of Mathematics Archive) 


\section{Bs $\mathrm{Bab} 3$}

\section{${ }_{\infty}^{\infty}$ LATIHAN}

Pada bagian ini, diberikan serangkaian latihan, dimana secara bertahap implementasi Metode Elemen Hingga ranah frekuensi untuk masalah sederhana, dimodifikasi tahap demi tahap sehingga dapat digunakan sebagai alat untuk memecahkan masalah persamaan Helmholtz yang muncul dalam aplikasi di bidang Elektromagnetik. Total tersedia 20 latihan, dari yang sifatnya sangat sederhana, sampai ke tingkat yang cukup sulit. Juga rentang aplikasinya, dari yang sifatnya pedagogis, sampai ke permasalahan garda depan (research frontier) di bidang nanosains, antara lain pada ranah gelombang TerraHertz serta aplikasi dalam disain divais seperti biosensor, sel surya dan antena nano.

Latihan 1-4 dapat dikatagorikan sebagai latihan sederhana yang harus dilakukan seusai mencoba skrip MATLAB, mengkaji studi kasus yang diberikan.

Latihan 5-10 dapat dikatagorikan sebagai latihan tingkat madya yang dapat diberikan sebagai tugas mandiri yang dapat dilakukan dalam waktu 2-3 minggu, mengingat diperlukan keterampilan untuk pembangkit mesh yang di buklet ini, digunakan distmesh, atau pembangkit mesh lainnya seperti gmesh.

Latihan 11-20 dikatagorikan sebuah latihan tingkat lanjut yang dapat dijadikan dasar penelitian tugas akhir S1, maupun bagian dari Thesis S2 maupun S3. Bahkan bisa menjadi bahan penelitian tersendiri. 


\subsection{Latihan 1. Pandu Gelombang Dua Lapis}

Pada kasus 2c dan 2d, ditunjukkan kemungkinan sifat bahan yang bervariasi.

Pada latihan ini, bertujuan bagaimana memodifikasi bangun sederhana yang telah diberikan, sehingga dapat mengakomodir sifat bahan yang konstan di sejumlah daerah. Dengan melakukan pembentukan elemen segi tiga kasar menurut bagian material sesuai dengan yang diinginkan, sering disebut sebagai body-fit triangulation.

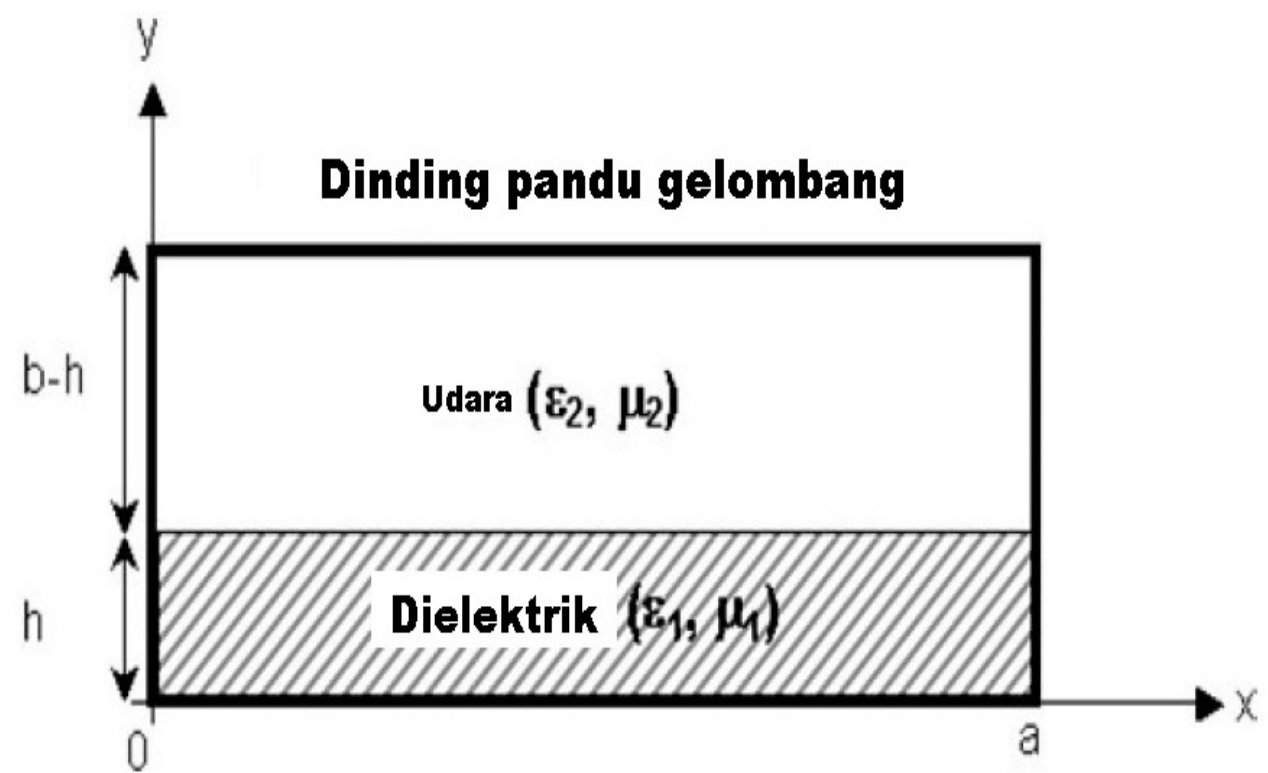

Gambar 3.1: Gambar untuk Latihan 1. Pandu gelombang persegi terisi dielektrik tak homogen. $\left[a=22.86 \mathrm{~mm}, b=10.16 \mathrm{~mm}, h=1 / 3 b, \varepsilon_{1}=2.56 \varepsilon_{0}, \varepsilon_{2}=\right.$ $\left.\varepsilon_{0}, \mu_{1}=\mu_{2}=\mu_{0}\right]$

Dengan nomor-nomor node, elemen segitiga dan edge syarat batas pada Tabel 3.1.

Definisikan geometri di atas dengan memanfaatkan triangulasi yang digunakan pada gambar 8 , sehingga simpul/nodes segitiga berada di atas dan tidak ada elemen segitiga yang melintang garis pemisah bahan.

Perhatikan bahwa, nilai koefisien $k$ akan bernilai konstan pada masing-masing segitiga. Susunlah sifat bahan yang dikaitkan pada elemen yang termuat di bagian tersebut sehingga pemberian sifat bahan pada elemen dapat dihitung saat assembly matriks massa. 


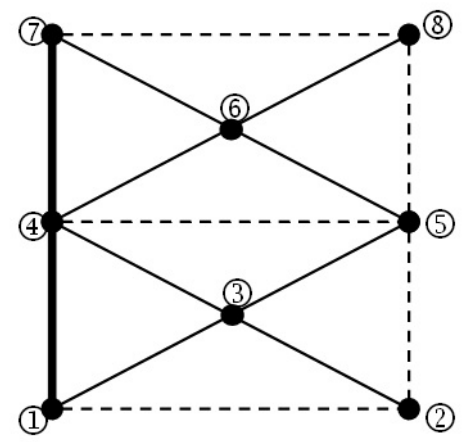

Gambar 3.2: Daerah $\Omega$ dibagi menjadi delapan segitiga

Tabel 3.1: Nomor-nomor node, elemen, dan edge syarat batas

\begin{tabular}{|c|c|c|c|c|}
\hline Nomor & $\begin{array}{c}\text { Node } \\
\text { (Koordinat) }\end{array}$ & $\begin{array}{c}\text { Elemen } \\
\text { Segitiga }\end{array}$ & $\begin{array}{c}\text { Syarat Batas } \\
\text { Neumann }\end{array}$ & $\begin{array}{c}\text { Syarat batas } \\
\text { Dirichlet }\end{array}$ \\
\hline 1. & $(0,0)$ & $1-2-3$ & $1-2$ & $7-4$ \\
\hline 2. & $(\mathrm{a}, 0)$ & $1-3-4$ & $2-5$ & $4-1$ \\
\hline 3. & $(1 / 2,1 / 4)$ & $3-2-5$ & $5-8$ & \\
\hline 4. & $(0, \mathrm{~h})$ & $4-3-5$ & $8-7$ & \\
\hline 5. & $(\mathrm{a}, \mathrm{h})$ & $4-5-6$ & & \\
\hline 6. & $(1 / 2,3 / 4)$ & $4-6-7$ & & \\
\hline 7. & $(0, \mathrm{~b})$ & $6-5-8$ & & \\
\hline 8. & $(\mathrm{a}, \mathrm{b})$ & $7-6-8$ & & \\
\hline
\end{tabular}




\subsection{Latihan 2. Test Dengan Solusi.}

Tujuan latihan berikut adalah melanjutkan latihan terdahulu, yaitu bagaimana menguji solusi numerik apabila solusi analitik permasalahan diketahui. Pada latihan berikut, akan diselesaikan masalah pandu gelombang untuk polarisasi-TM.

Masalah yang dihadapi adalah sebuah pandu gelombang yang merupakan struktur dengan permitivitas $\varepsilon$ bernilai konstan ke satu arah. Sehingga untuk sistem koordinat $(x, y)$ permitivitas hanya merupakan fungsi dari sumbu, dalam hal ini sumbu- $x$ saja. Perhatikan masalah nilai eigen berikut:

$$
\partial_{x x} \Psi(x)+k(x)^{2} \Psi(x)=\beta^{2} \Psi(x)
$$

dengan $k(x)^{2}=\varepsilon(x) \omega^{2} / c^{2}, u(x, y)=\Psi(x) \exp (i \beta y)$ yang memenuhi persamaan TMHelmholtz. Perhatikan bahwa jika $\beta \in R_{+}$medan merambat tanpa redaman ke arah sumbu $-y$ dan disebut sebagai moda terpandu.

Perlu diperhatikan bahwa solusi di atas tidak memenuhi syarat Sommerfeld, sehingga agar solusi analitik ini bisa digunakan sebagai pengujian untuk mendapatkan solusi analitik, maka daerah definisi merupakan daerah terbatas dengan syarat batas Neumann atau Dirichlet.

Sebagai contoh, perhatikan pandu gelombang dengan index melompat:

$$
k(x)^{2}=\left\{\begin{array}{l}
k_{2}^{2} \text { for }|x|<d, \\
k_{1}^{2} \text { for }|x|>d .
\end{array}\right.
$$

Dalam hal ini, $2 d$ merupakan lebar dari pandu gelombang, dan kita anggap $k_{2}^{2}>$ $k_{1}^{2}$. Moda dasar (fundamental mode) $u$-yg belum tentu ada, terkait dengan fungsieigen $\Psi(x)$ dengan nilai maksimal $\beta^{2}$ diberikan oleh

$$
u(x, y)=\left\{\begin{array}{l}
\left(e^{i \sqrt{k_{2}^{2} \beta^{2}} x}+e^{i \sqrt{k_{2}^{2} \beta^{2}} x}\right) e^{i \beta y}, \text { untuk }|x|<d, \\
C e^{\sqrt{-k_{1}^{2}+\beta^{2}} x} e^{i \beta y}, \text { untuk } x<=-d, \\
C e^{\sqrt{-k_{1}^{2}+\beta^{2}} x} e^{i \beta y}, \text { untuk } x>d,
\end{array}\right.
$$

dengan $C=\left(\exp \left(i \sqrt{k_{2}^{2} \beta^{2}} d\right)+\exp \left(i \sqrt{k_{2}^{2} \beta^{2}} d\right)\right) / \exp \left(\sqrt{k_{1}^{2}+\beta^{2}} d\right)$. Perhatikan bahwa moda fundamentalnya meluruh dengan cepat secara eksponensial untuk $|x| \rightarrow \infty$.

Untuk eksperimen Numerik, dipilih $d=1 / \sqrt{2}, k_{1}=0.29$ dan $k_{2}=1.32$. Pemilihan ini, akan mendapatkan moda fundamental $\beta=0.8767339289$.

Gunakan gambar geometri pada Latihan 2., dan gunakan parameter yang diberikan untuk persamaan (3.1), serta tentukan jenis syarat batasnya berdasarkan solusi eksak (3.1) yang diberikan. 


\subsection{Latihan 3. Geometri Bahan Berbeda.}

Latihan ini, bertujuan melakukan penyusunan geometri yang bersesuaian dengan sifat bahan yang digunakan, Lihat juga kasus (2c) dan Latihan 1.
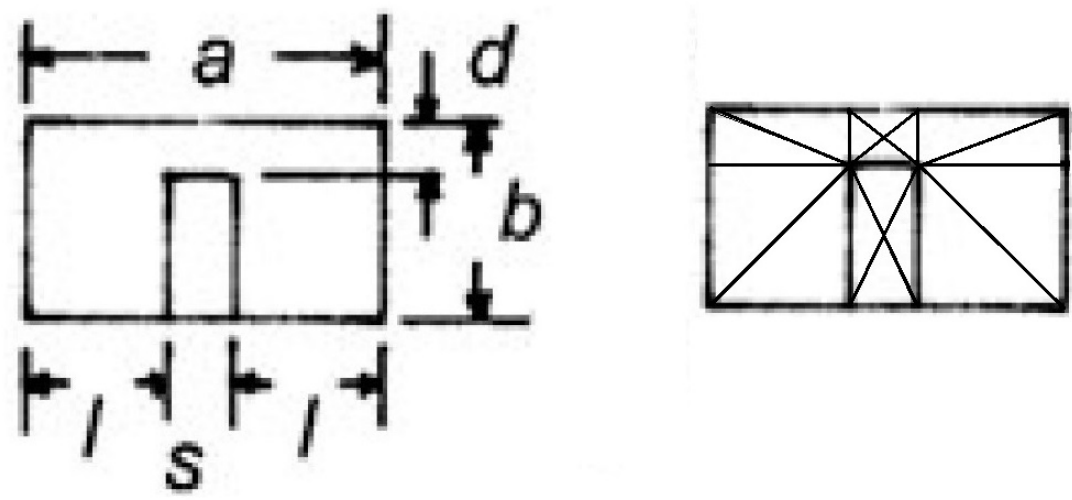

Gambar 3.3: Latihan 3. Pandu Gelombang Ridge

Dalam latihan ini, terdiri dari 2 bagian bahan yang menempati daerah tertentu. Susunlah sifat bahan yang dikaitkan pada elemen yang termuat di bagian tersebut sehingga pemberian sifat bahan pada elemen dapat dihitung saat assembly matriks massa. 


\subsection{Latihan 4. Perambatan Gelombang Dalam Ruang Akibat Sumber WiFi.}

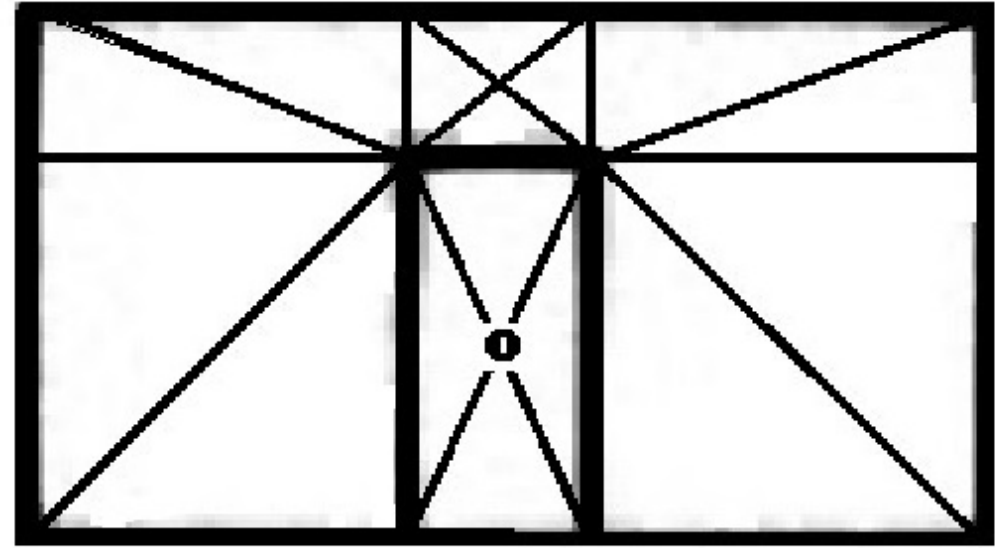

Gambar 3.4: Sketsa tapak ruangan dengan posisi router WiFi berada di titik o.

Pada latihan ini, meskipun tidak menyangkut pandu gelombang, memodelkan perambatan medan listrik akibat adanya sumber. Dalam hal ini, memodelkan perambatan medan elektrik di dalam ruangan akibat adanya router $\mathrm{WiFi}$.

$$
-\nabla^{2} u+l^{2} u=f
$$

dengan $f$ menyatakan sumber pemancar WiFi. Implementasi dalam MATLAB, hanya dengan menambah satu rutin serupa dengan konstruksi matriks massa. Dengan mengingat bahwa, cukup diperlukan evaluasi $\int f \varphi_{j} d x d y$, untuk sembarang fungsi basis $\varphi_{j}$. 


\section{${ }_{735}^{73}$ 3.5 Latihan 5. Syarat Batas Serap}

Dalam banyak permasalahan, diperlukan situasi perambatan medan, dimana seakan tidak ada pembatas yang menghalangi. Syarat batas yang secara fisik lebih realistis ialah menjamin bahwa semua gelombang dari daerah komputasi akan merambat keluar tanpa kecuali, sedikitpun tak ada yang kembali. Diperlihatkan di ([3], halaman 16) bahwa syarat batas seperti ini adalah syarat batas jenis Robin, yaitu

$$
\frac{\partial u}{\partial n}-\imath k u=0 \text { di } \partial \Omega
$$

741 dengan $\imath=\sqrt{-1}$. Implementasikan pada Latihan 1, dengan memodifikasi bentuk sya-

${ }_{742}$ rat batas yang mirip dengan syarat-Neumann yang tak homogen $: \frac{\partial u}{\partial n}=g, g:=\imath k u$. 


\section{${ }_{743} 3.6$ Latihan 6. Geometri Cincin}

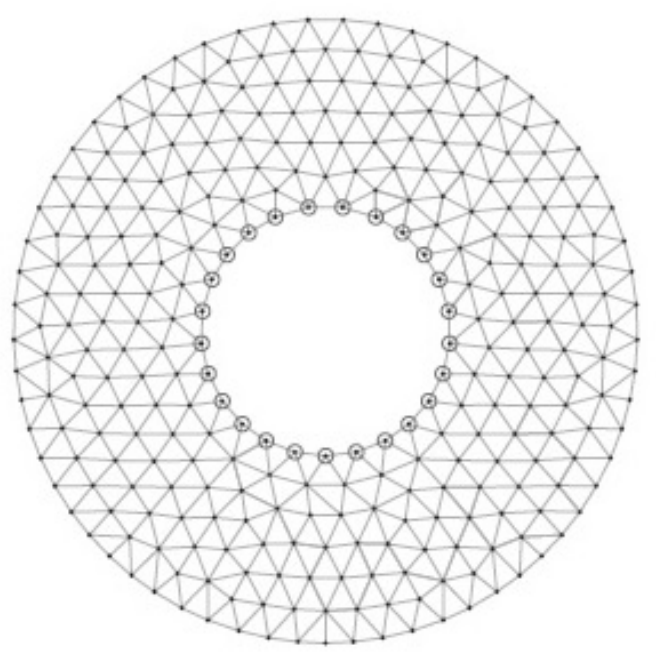

Gambar 3.5: Ilustrasi mesh $\Omega$ berupa lingkaran bolong

Pada latihan ini, dengan menggunakan geometri sebagaimana diberikan di Lampiran, untuk menyelesaikan persamaan Helmholtz berbentuk:

$$
-\nabla^{2} u+l^{2} u=f .
$$

Jika pada lingkaran bagian dalam berupa syarat batas Dirichlet, coba bereksperimen untuk syarat batas dengan melakukan eksperimen numerik, dengan menetapkan pada batas lingkaran terluar dengan syarat batas Dirichlet, Neumann, atau Robin sebagaimana dibahas di latihan sebelum ini. 


\subsection{Latihan 7. Tomografi Microwave Meman- jang}

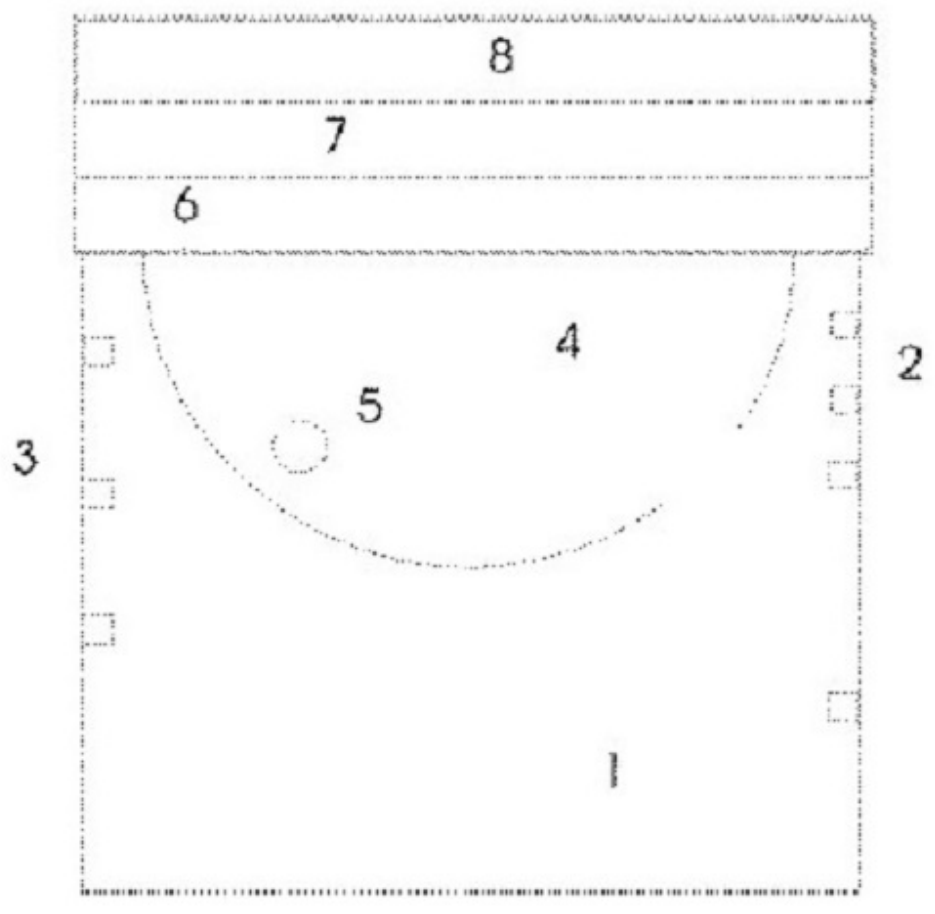

Gambar 3.6: Skematik masalah. Potongan melintang dari alat Microwave dan model. 1. Ruang kerja; 2: Serangkaian transmitter; 3: Serangkaian penerima; 4: Setengah bola; 5: Area kecil nonhomogen; 6:Lapisan lemak; 7: Lapisan otot; 8: Lapisan tulang.

756

757

Pada latihan ini, diberikan model perambatan Microwave memanjang [4] untuk Tomografi Microwave.

Sebagaimana disebutkan, persamaan Helmholtz skalar memodelkan perambatan elektromagnetik di ruang bebas dan di dalam objek:

$$
-\nabla^{2} E_{s}+k^{2} E_{s}=\left(k_{0}^{2}-k^{2}\right) E_{0}
$$

dengan

$E_{s}$ dan $E_{0}$ komponen medan datang dan hamburan

$k \quad$ bilangan gelombang

$k_{0}^{2} \quad=(2 \pi / \lambda)^{2} \varepsilon$

$\lambda \quad$ panjang gelombang radiasi dalam vakum 
Dalam eksperimen numerik, digunakan medan sumber titik sebagai medan datang

$$
E_{0}(r)=\frac{\exp \left(i k_{0} r\right)}{4 \pi r}
$$

dengan $r$ menyatakan jarak titik sumber dengan pusat fasa antenna pemancar, $k_{0}$ menyatakan bilangan gelombang untuk ruang homogen.

\begin{tabular}{|c|c|c|}
\hline Lemak & $\varepsilon_{f}$ & $10+\imath$ \\
\hline Tulang & $\varepsilon_{b}$ & $11+2 \imath$ \\
\hline Otot & $\varepsilon_{m}$ & $25+15 \imath$ \\
\hline Jaringan Payu Dara & $\varepsilon_{b t}$ & $10+1.5 \imath$ \\
\hline Jaringan malignan & $\varepsilon_{c}$ & $23+15 \imath$ \\
\hline
\end{tabular}




\section{${ }_{763} 3.8$ Latihan 8. Tomografi Microwave Melintang}

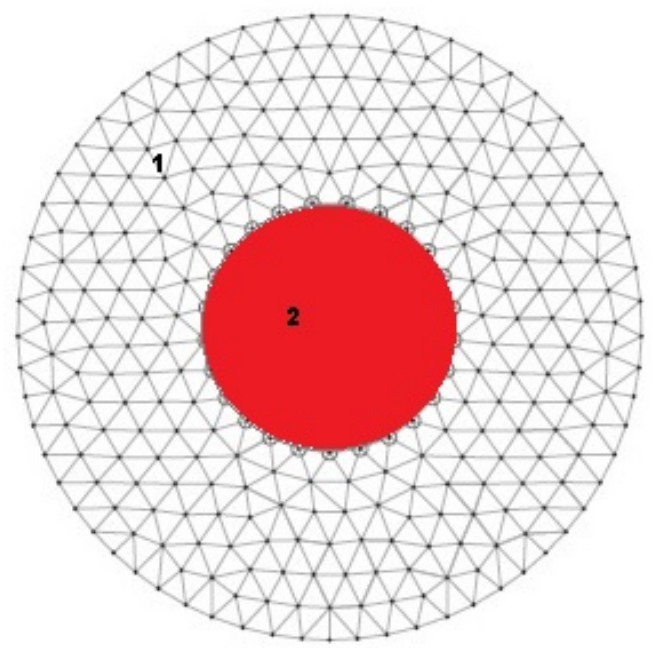

Gambar 3.7: Skematik Microwave Tomography untuk potongan melintang pada Latihan 7. Dengan susunan bahan berupa 1: Lapisan Lemak; 2: Anomali

Pada latihan ini, dengan memanfaatkan triangulasi sebagaimana di Lampiran untuk pembangkitan grid, direpresentasikan model perambatan medan Elektrik secara melintang mengikuti model dan sifat bahan pada Latihan 8. 


\subsection{Latihan 9. Biosensor Bakteria Berlapis.}

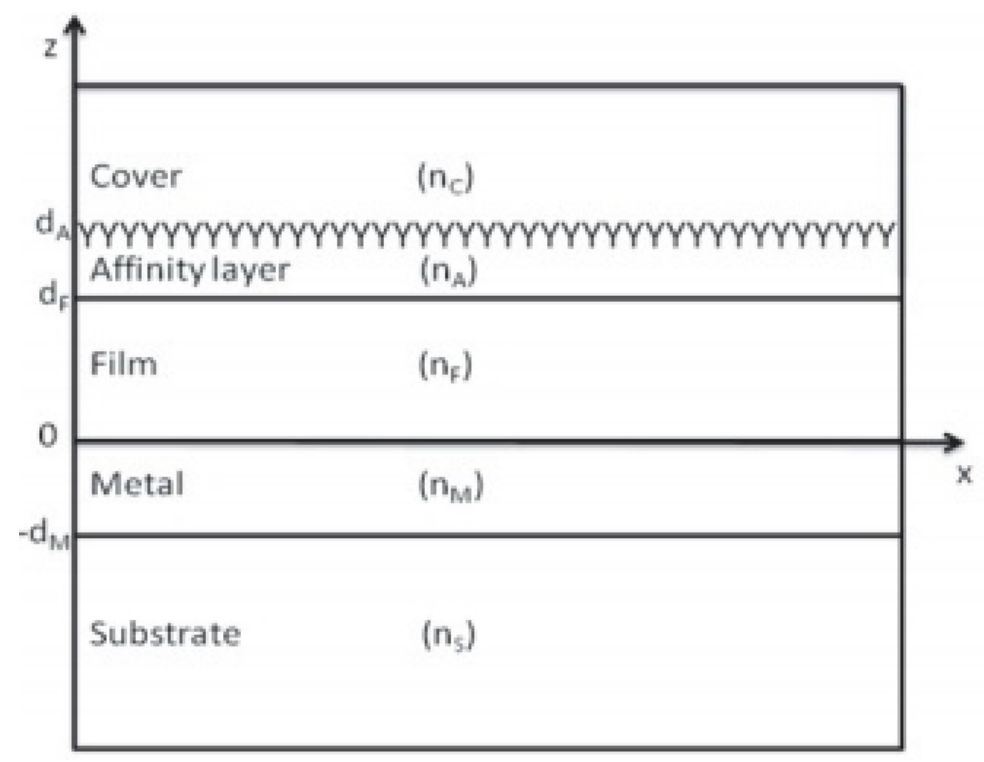

Gambar 3.8: Biosensor pendeteksi Bakteri berupa pandu gelombang dengan 5 lapis. Dengan syarat batas Neumann di dinding kiri/kanan, dan Dirichlet di atap dan dasar.[24]

Secara matematis, permasalahan pada latihan ini, hampir serupa dengan Latihan 2. Yaitu, pada hakekatnya, menyelesaikan persamaan Helmholtz dengan koefisien yang bervariasi relatif terhadap satu arah sumbu.

Parameter yang digunakan dalam latihan ini, diberikan sebagai berikut :

Panjang gelombang operasional: $\lambda_{0}=0.6328 \mu \mathrm{m}$. Indeks refraktif substrat, metal, dan film secara berturutan $n_{S}=1.495, n_{M}=0.064+4 \imath, n_{F}=0.15+3.2 \imath$. Lebar lapisan metal dan film $d_{M}=0.03 \mu m, d_{F}=0.5 \mu m$. Indeks Refraktif beberapa bahan uji: toluena $=1.49268$, nikotin $=1.5265$.

Data eksperimen untuk pandu gelombang dengan cladding perak, secara bervariasi digunakan 3 eksperimen numerik berikut ini:

- $n_{s}=1.49, n_{F}=1,59, d_{M}=0.03 \mu m, d_{F}=0.5 \mu m, d_{A}=0.06 \mu m$.

- $n_{s}=1.49, n_{F}=1,59, d_{M}=0.5 \mu m, d_{F}=0.03 \mu m, d_{A}=0.045 \mu m$.

- $n_{s}=1.49, n_{F}=1,59, d_{M}=0.03 \mu m, d_{F}=0.5 \mu m, d_{A}=0.04 \mu m$. 


\subsection{Latihan 10. Biosensor Resonator Cincin.}

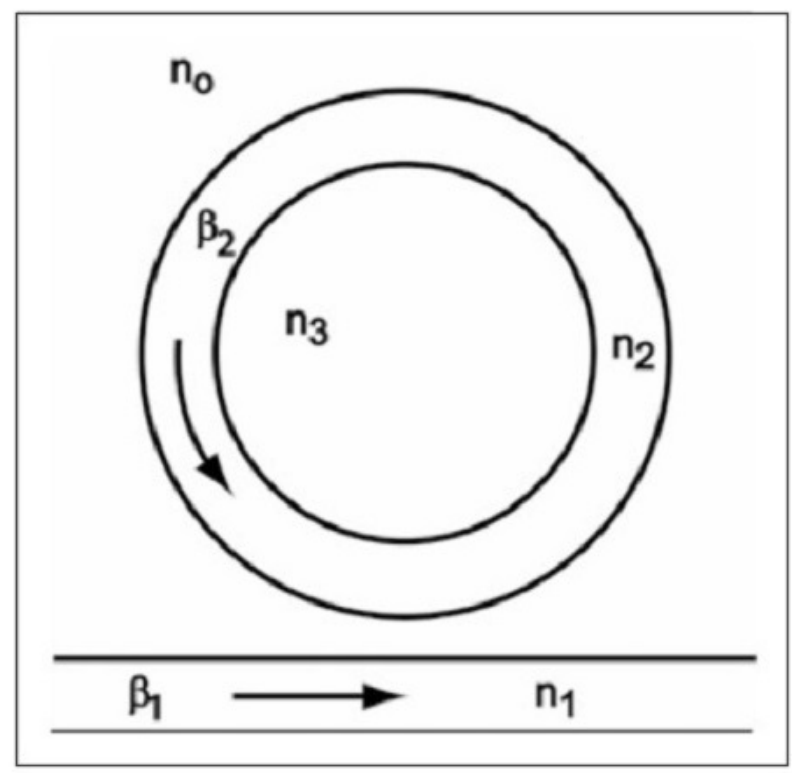

Gambar 3.9: Biosensor deteksi gas berupa gabungan pandu gelombang dan cincin resonator. Syarat batas Neumann di dinding kiri/kanan, dan di atap, Dirichlet pada dasar. $\beta_{1,2}$ secara berturutan merupakan konstanta perambatan di pandu gelombang dan cincin resonator. $n_{0,1,2,3}$ secara berturutan merupakan indeks refraktif di udara, pandu gelombang, cincin resonator, dan air.[5]

Indeks refraktif resonator cincin terbuat dari gelas : 1.52 , Indeks refraktif pandu gelombang terbuat dari Silikon Oksida : 1.468, Indeks refraktif udara : 1.0, Indeks refraktif air : 1.333. Sumber cahaya eksitasi berupa sinar laser ditembakkan dari sisi kiri pandu gelombang pada panjang gelombang :[1,530,1.560] $\mathrm{nm}$ Diameter resonator : $100 \mu \mathrm{m}$, Tebal resonator : $3 \mu \mathrm{m}$, Tebal pandu gelombang : $2 \mu \mathrm{m}$, Variasi celah pandu gelombang dan resonator : [0, 100, 200,300] $\mu \mathrm{m}$.

\section{Latihan 10a. Sensor MEMS (Catatan)}

Dalam [28], struktur resonator dan pandu gelombang digunakan sebagai sensor MEMS untuk sensor tekanan dengan memanfaatkan efek Fano. Selain untuk menyelesaikan persamaan Helmholtz dengan menggunakan FEFD sebagaimana diuraikan di dalam buklik ini, diperlukan simulasi tambahan untuk medan elastik dan termal yang dapat diselesaikan dengan metode Galerkin dengan cara memodifikasi beberapa baris MATLAB/OCTAVE di Alberty dkk [1]. 


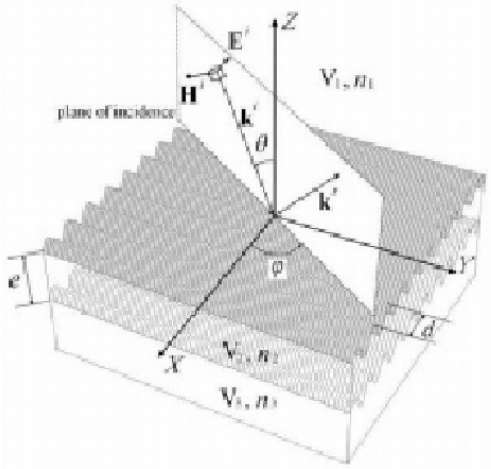

Solusi harus bersifat : difraksinya. Magnetik harus kontinu.

\subsection{Latihan 11. Biosensor Sisir/bergerigi Plas- monik}

Permasalahan yang dihadapi [17] adalah mencari difraksi dari medan Elektrik dan Magnetik dalam $V_{j}(j=1,2,3)$. Perhatikan bahwa setiap komponen TE maupun TM di setiap arah ada karena diasumsikan pemasangan kerucut.

- Berlaku persamaan Helmholtz di kedua daerah;

- syarat kondisi radiatif ke arah-Z bahwa gelombang ke arah $V_{1}$ (atau $V_{3}$ ) menjalar atau mengalami attenuasi ke arah $Z$ positif (atau negatif);

- Syarat periodik bahwa berlaku hubungan $f(X+d, Y, Z)=f(X, Y, Z)$, serta konstanta fase dalam $Y$ adalah $\beta$ untuk setiap komponen dari setiap cahaya

- Syarat batas di $S_{1}$ dan $S_{2}$ bahwa komponen tangensial medan Elektrik dan

Gambar 3.10: Biosensor plasmonik. Skematik dari difraksi oleh kisi metal berlapis dan definisi dari sudut polarisasi.

Parameter yang digunakan adalah $2 h=0.072 \mu m, d=0.556 \mu m$ dan $e=0778 \mu m$. Sumber cahaya berupa gelombang bidang monokromatik dengan panjang gelombang $0.633 \mu \mathrm{m}$. Sementara indeks refraktif dari aluminium dan emas $n_{2}=0.1594+\imath 3.2166$ dan $n_{3}=1.2078+\imath 7.0148$ 


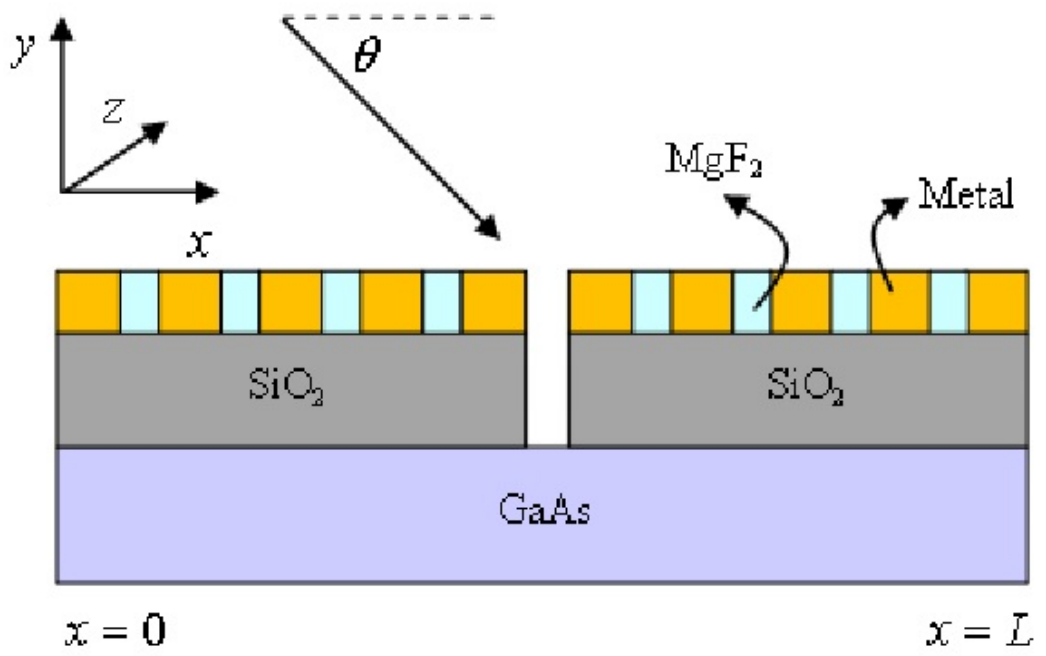

Gambar 3.11: Biosensor plasmonik. Skematik dari difraksi oleh kisi metal berlapis dan definisi dari sudut polarisasi. [18]

Pada latihan ini, merupakan varian dari latihan 11, dimana salah satu celah gerigi memiliki kedalaman yang lebih dari kedalaman gerigi yang lain.

Parameter yang digunakan sebagai berikut : indeks refraksi slab $: n_{s l}=1.45$

indeks refraksi substrat $: n_{s u}=2.21$

ketebalan slab $\quad: h_{s l}=60 \mu \mathrm{m}$

819

ketebalan substrat

$\begin{array}{ll}: & h_{s l}=60 \mu \mathrm{m} \\ : & h_{s u}=80 \mu \mathrm{m}\end{array}$

perioda gerigi

: $\Lambda=31 \mu \mathrm{m}$

panjang

: $L=300 \mu m$ 


\subsection{Latihan 13. SPR (Surface Plasmon Resonan- ce) Sensor.}

\section{$7.0 \mu \mathrm{m}$}

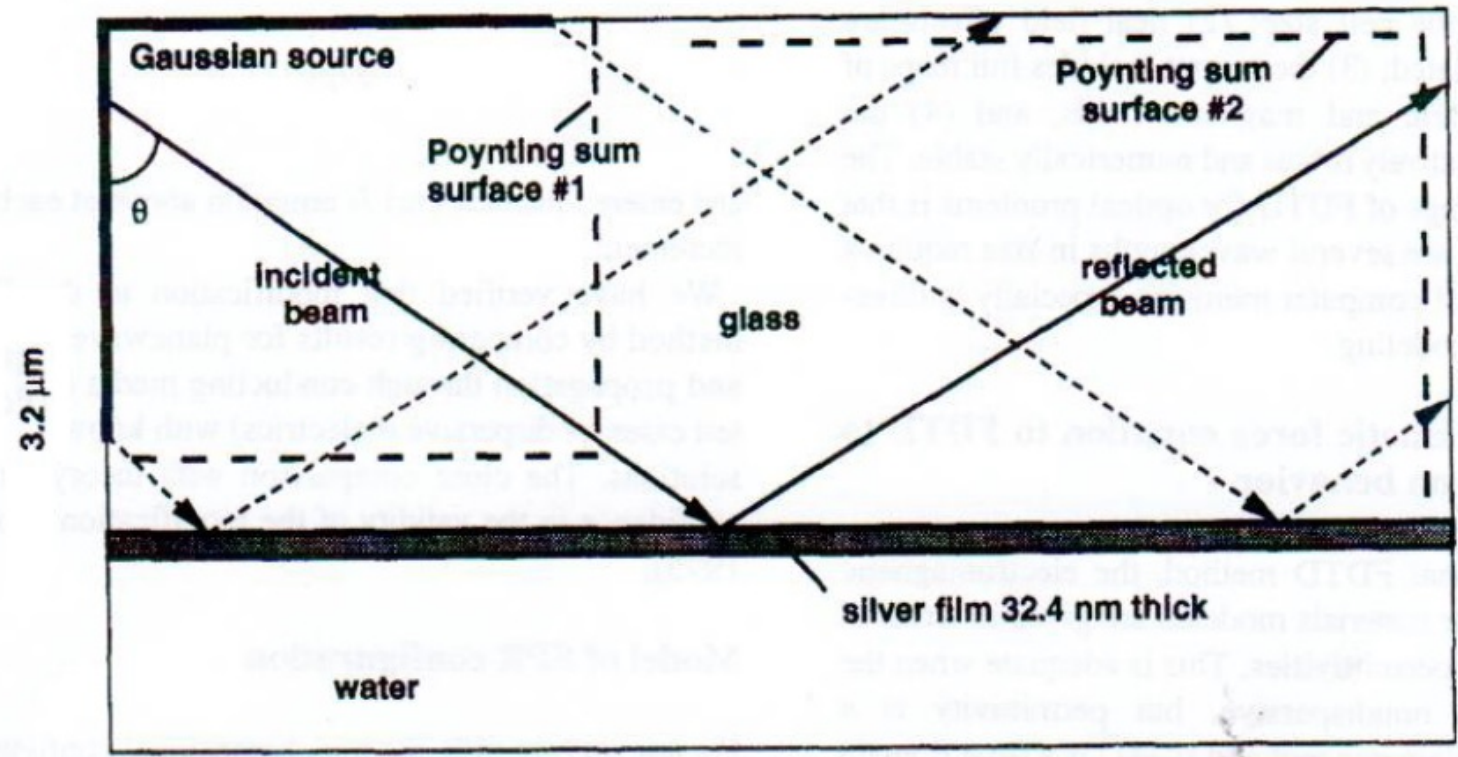

Gambar 3.12: SPR Sensor, sensor yang memanfaatkan resonansi permukaan plasmonik.

Besaran fisis yang digunakan untuk SPR:[6]

indeks refraksi slab gelas $: n_{s l}=1.52$

indeks refraksi metal

$: n_{A g}=2.21$

ketebalan slab gelas

: $h_{s l}=3.2 \mu \mathrm{m}$

ketebalan metal

panjang

: $h_{A g}=32.4 \mathrm{~nm}$

: $L=7.0 \mu \mathrm{m}$ 
${ }_{824}$ 3.14 Latihan 14. Sel Surya Plasmonik.

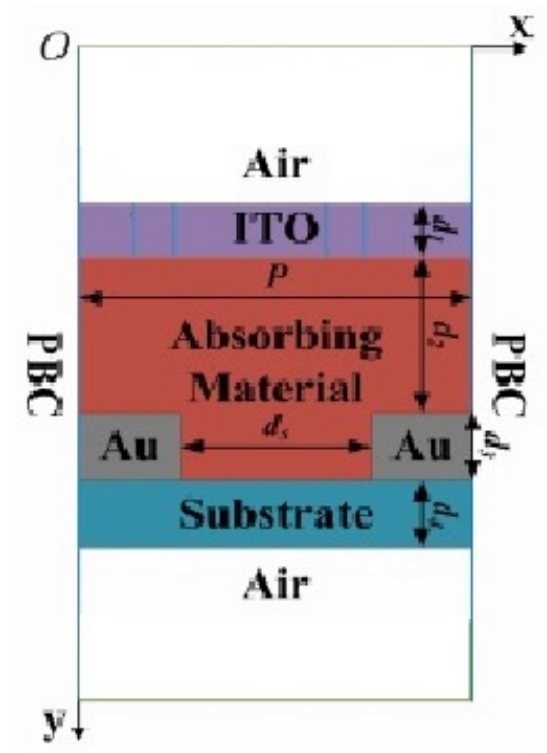

Gambar 3.13: Unit sel dari sel surya plasmonik lapis tipis. Tersusun dari 4 lapisan terdiri dari Indium Tin Oxide (ITO), bahan penyerap, elektroda emas $(\mathrm{Au})$ atau perak $(\mathrm{Ag})$, dan substrat. Cahaya datang dari arah atas melewati ITO.

Sel Surya plasmonik. Unit sel dari sel surya plasmonik lapis tipis. Tersusun dari 4 lapisan terdiri dari Indium Tin Oxide (ITO), bahan penyerap, elektroda emas (Au) atau perak $(\mathrm{Ag})$, dan substrat dengan ketebalan masing-masing secara berturutan $d_{1}=25 \mathrm{~nm}, d_{2}=120 \mathrm{~nm}, d_{3}=40 \mathrm{~nm}$, dan $d_{4}=40 \mathrm{~nm}$. Jarak antara dua elektroda berturutan $d_{s}=100 \mathrm{~nm}$ dan periode $P=200 \mathrm{~nm}$. Cahaya datang dari arah atas melewati ITO. [29] 


\subsection{Latihan 15. Sel Surya Plasmonik dengan PML.}

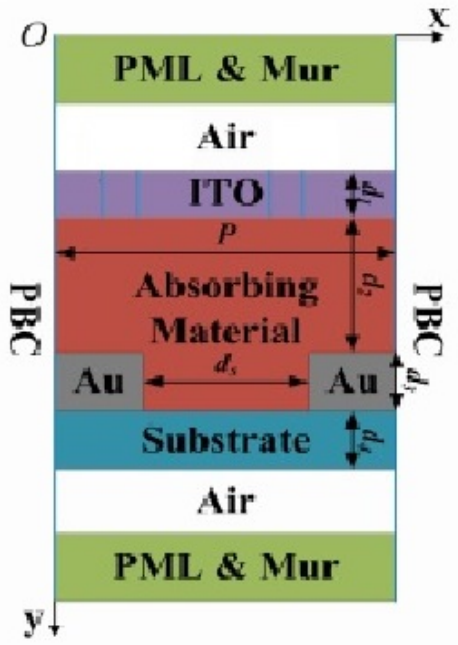

Gambar 3.14: Sel Surya plasmonik. Unit sel dari sel surya plasmonik lapis tipis. Tersusun dari 4 lapisan terdiri dari Indium Tin Oxide (ITO), bahan penyerap, elektroda emas $(\mathrm{Au})$ atau perak $(\mathrm{Ag})$, dan substrat dengan ketebalan masing-masing secara berturutan $d_{1}, d_{2}, d_{3}$, dan $d_{4}$. Jarak antara dua elektroda berturutan $d_{s}$ dan periode $P$ (lihat Latihan 4 untuk ukurannya). Cahaya datang dari arah atas melewati ITO. Idealnya syarat batas PML diberikan pada atap dan dasar, serta syarat batas periodik di kiri-kanan [29]

Sebagaimana diperlihatkan di atas, ke arah $y$ diperlukan syarat batas penyerap (Absorbing Boundary Conditions, $\mathrm{ABC}$ ) agar tidak terjadi pantulan gelombang yang sifatnya artifisial di bagian atas dan bawah. Salah satu bentuk ABC adalah berbentuk seperti ini:

$$
\frac{\partial^{2} u}{\partial^{2} x}+\frac{1}{s_{y}} \frac{\partial}{\partial y} \frac{1}{s_{y}} \frac{\partial u}{\partial y}+k_{0}^{2} u=0, \text { dengan } s_{y}=\left\{\begin{array}{l}
1-j \frac{\sigma(y)}{\omega \varepsilon_{0}} \text { di dalam PML } \\
1, \text { lainnya. }
\end{array}\right.
$$




\subsection{Latihan 16. Alat uji NDT (Non Destructive Testing) pada gelombang THz.}

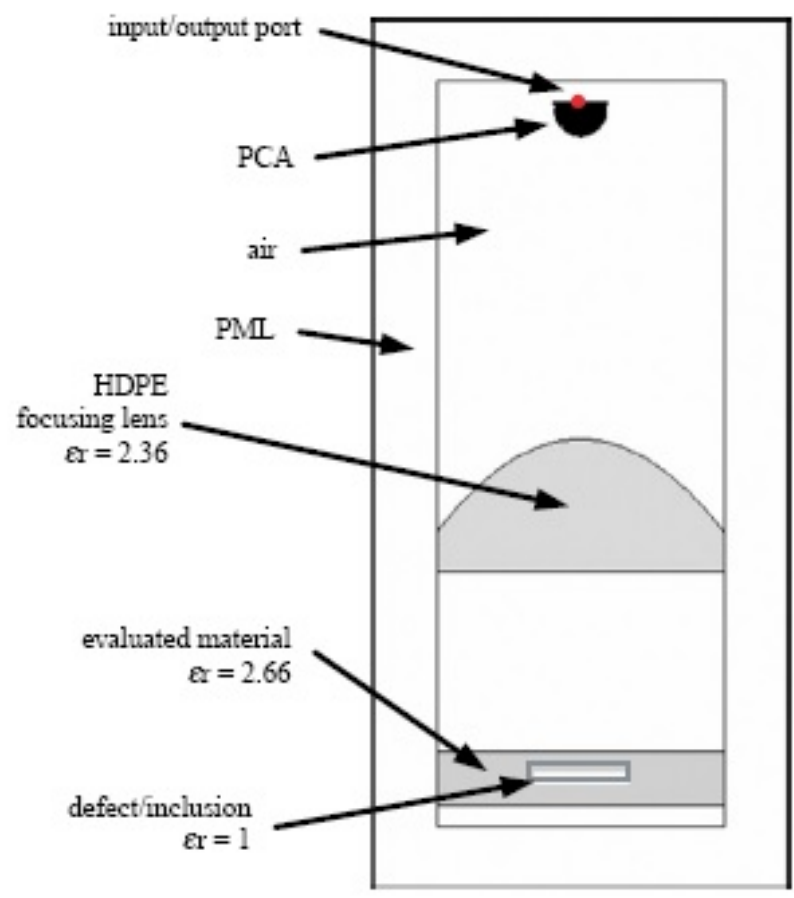

Gambar 3.15: Alat uji NDT gelombang THz. Tersusun dari 3 domain terdiri dari udara, lensa dielektrik, dan benda uji yang memiliki cacat (defect). Sumber gelombang datang dari port di bagian atas. Syarat batas PML diberikan pada atap dan dasar, serta sisi di kiri-kanan[15].

Sebagaimana diperlihatkan di atas, ke arah $y$ diperlukan syarat batas penyerap (ABC, 'Absorbing Boundary Conditions') agar tidak terjadi pantulan gelombang yang sifatnya artifisial di bagian atas dan bawah.

$$
\frac{\partial^{2} u}{\partial x^{2}}+\frac{1}{s_{y}} \frac{\partial}{\partial y} \frac{1}{s_{y}} \frac{\partial u}{\partial y}+k_{0}^{2} u=0, \text { dengan } s_{y}=\left\{\begin{array}{l}
1-j \frac{\sigma(y)}{\omega \varepsilon_{0}} \text { di PML atas } / \text { bawah } \\
1, \text { lainnya. }
\end{array}\right.
$$

Begitu pula ke arah $x$ diperlukan syarat batas penyerap (ABC, 'Absorbing Boundary Conditions') agar tidak terjadi pantulan gelombang yang sifatnya artifisial di bagian kiri dan kanan.

$$
\frac{1}{s_{x}} \frac{\partial}{\partial x} \frac{1}{s_{x}} \frac{\partial u}{\partial x}+\frac{\partial^{2} u}{\partial y^{2}}+k_{0}^{2} u=0, \text { dengan } s_{x}=\left\{\begin{array}{l}
1-j \frac{\sigma(x)}{\omega \varepsilon_{0}} \text { di PML kiri/kanan } \\
1, \text { lainnya. }
\end{array}\right.
$$


Sementara di pojok atas/bawah-kiri/kanan,

$$
\frac{1}{s_{x}} \frac{\partial}{\partial x} \frac{1}{s_{x}} \frac{\partial u}{\partial x}+\frac{1}{s_{y}} \frac{\partial}{\partial y} \frac{1}{s_{y}} \frac{\partial u}{\partial y}+k_{0}^{2} u=0,
$$

848

$$
\text { dengan }\left\{\begin{array}{l}
s_{x}=1-j \frac{\sigma(x)}{\omega \varepsilon_{0}} \\
s_{y}=1-j \frac{\sigma(y)}{\omega \varepsilon_{0}}
\end{array} \quad\right. \text { di PML pojok atas/bawah-kiri/kanan }
$$
850 dari sumber. 
${ }_{\text {ss1 }}$ 3.17 Latihan 17. Nanowire.

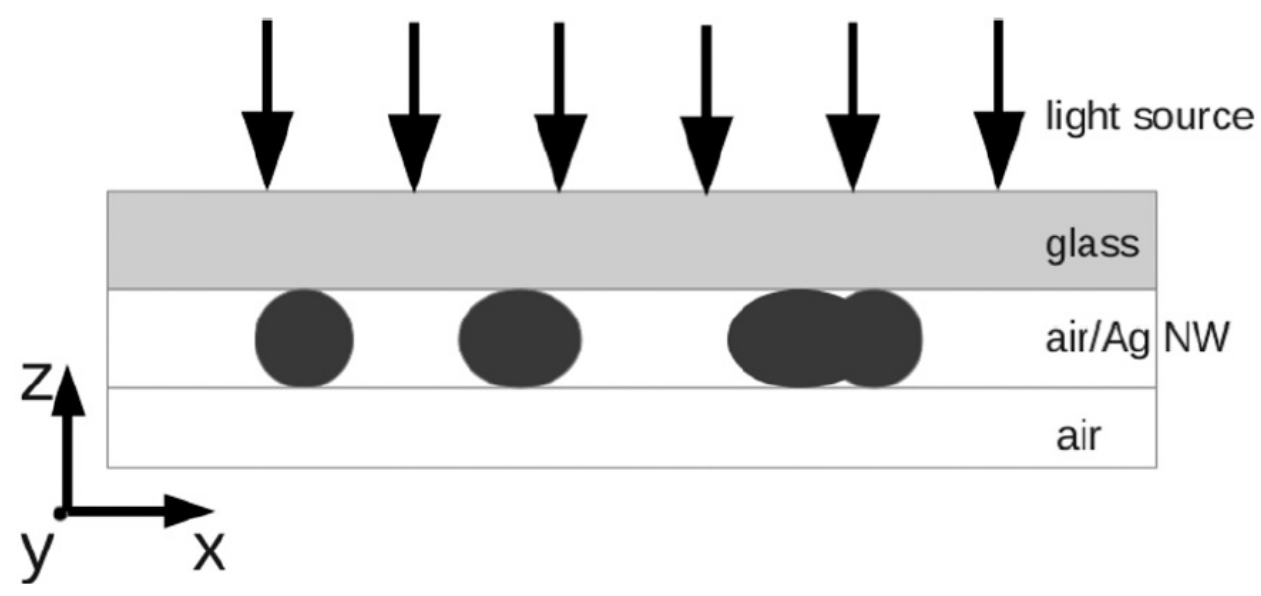

Gambar 3.16: SPR Sensor yang memanfaatkan struktur Nanowire metal[30], alih-alih menggunakan lapisan tipis sebagaimana pada Latihan 13.

Bandingkan dengan latihan 13, SPR sensor yang memiliki struktur yang serupa. indeks refraksi slab gelas $: n_{s l}=1.52$ indeks refraksi metal $\quad: n_{A g}=2.21$

ketebalan slab gelas $\quad: h_{s l}=3.2 \mu m$

ketebalan metal $\quad: h_{A g}=32.4 n m$

panjang

: $L=7.0 \mu \mathrm{m}$ 


\section{${ }_{854}$ 3.18 Latihan 18. Antena Nano}

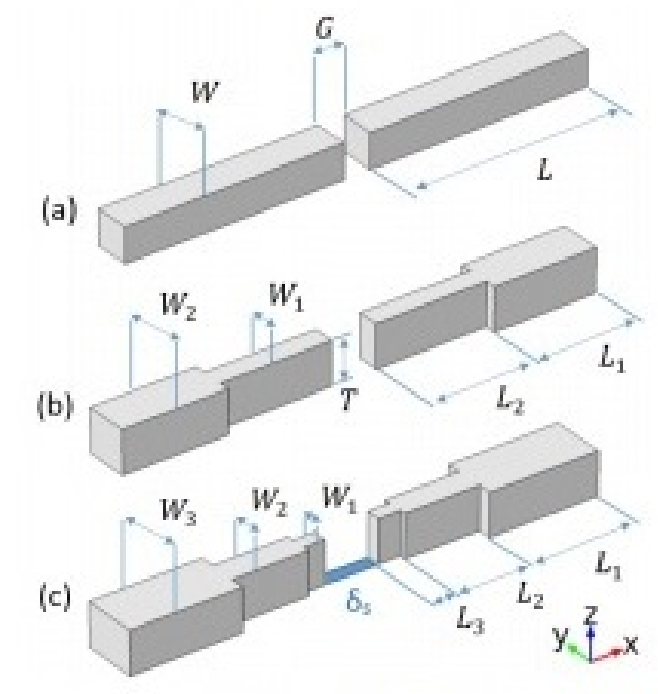

Gambar 3.17: Struktur Antenna Nano [7] terbuat dari perak. (a). Antena dipol nano. (b) Jenis-1, Antena dipol nano bertangga 2 (2-steps tapered dipole). (c) Jenis-2, Antena dipol nano bertangga 3 (3-steps tapered dipole). Panjang gelombang operasional $\lambda=300 \mathrm{~nm}$. Syarat batas PML

\begin{tabular}{|c|c|c|c|}
\hline $\begin{array}{c}\text { Antenna } \\
\text { parameters }\end{array}$ & $\begin{array}{c}\text { conventional } \\
\text { dipole }\end{array}$ & Type 1 & Type 2 \\
\hline$T$ & $40 \mathrm{~nm}$ & $40 \mathrm{~nm}$ & $40 \mathrm{~nm}$ \\
\hline$G$ & $10 \mathrm{~nm}$ & $41.3 \mathrm{~nm}$ & $49.8 \mathrm{~nm}$ \\
\hline$L_{1}$ & $250 \mathrm{~nm}$ & $97.5 \mathrm{~nm}$ & $103.5 \mathrm{~nm}$ \\
\hline$W_{1}$ & $40 \mathrm{~nm}$ & $31.3 \mathrm{~nm}$ & $51 \mathrm{~nm}$ \\
\hline$L_{2}$ & - & $103.4 \mathrm{~nm}$ & $70 \mathrm{~nm}$ \\
\hline$W_{2}$ & - & $11.6 \mathrm{~nm}$ & $19.5 \mathrm{~nm}$ \\
\hline$L_{3}$ & - & - & $5 \mathrm{~nm}$ \\
\hline$W_{3}$ & - & - & $13.4 \mathrm{~nm}$ \\
\hline $\begin{array}{l}\text { Relative } \\
\text { volume }\end{array}$ & 1 & 0.42 & 0.67 \\
\hline
\end{tabular}

Gambar 3.18: Dimensi rancangan antenna dipol dalam nanometer 


\subsection{Latihan 19. Antena Nano Pemanen Energi Surya.}

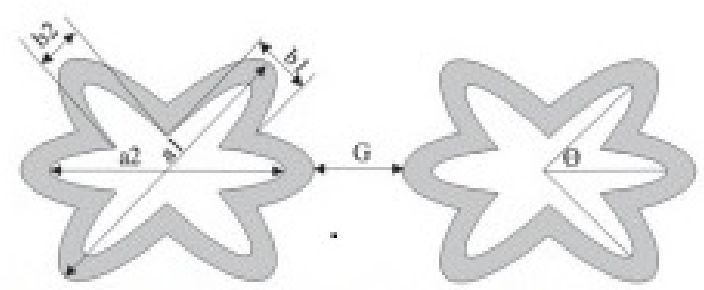

Gambar 3.19: Struktur antena nano pemanen energi surya dari perak berbentuk kembang[9]. Panjang gelombang operasional $\lambda=300-1400 \mathrm{~nm}$

857 Ukuran:

${ }_{858} a_{1}=125 \mathrm{~nm}, b_{1}=40 \mathrm{~nm}, a_{2}=100 \mathrm{~nm}, b_{2}=20 \mathrm{~nm}, \mathrm{G}=10 \mathrm{~nm}, \theta=10^{\circ}, \mathrm{L}=40 \mathrm{~nm}$. 
${ }_{8 s 9} 3.20$ Latihan 20. Antena Nano Asimetrik.
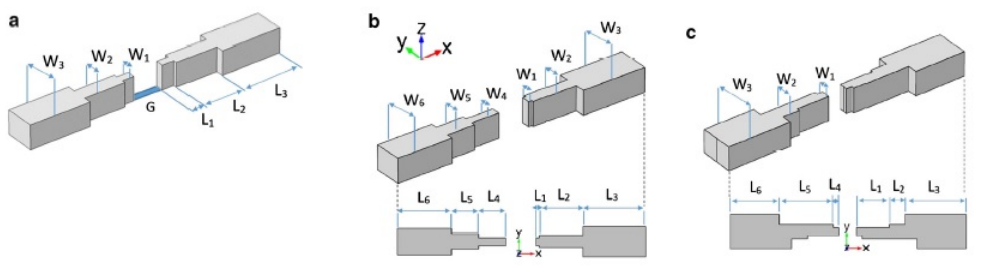

Gambar 3.20: Struktur antena nano asimetrik[8] terbuat dari perak. Panjang gelombang operasional $\lambda=300 \mathrm{~nm}$. Syarat batas PML

\begin{tabular}{clll}
\hline Antenna parameters & Tapered dipole & Asymmetric dipole_case 1 (nm) & Asymmetric dipole-case 2 \\
\hline$T$ & $40 \mathrm{~nm}$ & 40 & $40 \mathrm{~nm}$ \\
$G$ & $49.8 \mathrm{~nm}$ & 41.3 & $49.8 \mathrm{~nm}$ \\
$L_{1}$ & $5 \mathrm{~nm}$ & 5.4 & $6 \mathrm{~nm}$ \\
$L_{2}$ & $70 \mathrm{~nm}$ & 60.6 & $99.7 \mathrm{~nm}$ \\
$L_{3}$ & $103.5 \mathrm{~nm}$ & 102.9 & $90.6 \mathrm{~nm}$ \\
$W_{1}$ & $13.4 \mathrm{~nm}$ & 12 & $5 \mathrm{~nm}$ \\
$W_{2}$ & $19.5 \mathrm{~nm}$ & 23.6 & $15 \mathrm{~nm}$ \\
$W_{3}$ & $51 \mathrm{~nm}$ & 60 & $60 \mathrm{~nm}$ \\
$L_{4}$ & - & 23.6 & $56.5 \mathrm{~nm}$ \\
$L_{5}$ & - & 43.7 & $28.9 \mathrm{~nm}$ \\
$L_{6}$ & - & 101.6 & $110.8 \mathrm{~nm}$ \\
$W_{4}$ & - & 12 & - \\
$W_{5}$ & - & 27.8 & - \\
$W_{6}$ & - & 59.9 & - \\
\hline
\end{tabular}

Gambar 3.21: Dimensi rancangan antenna dipol asimetrik dalam nanometer. 


\section{${ }_{860} \mathrm{Bab} 4$}

\section{Penutup}

Baris demi baris perintah dalam MATLAB yang berhubungan langsung dengan implementasi FEM. Ditunjukkan bagaimana FEM diperkenalkan kepada mahasiswa hanya menggunakan beberapa baris kode MATLAB. Beberapa studi kasus yang lengkap script MATLABnya yang diberikan dapat dijalankan pada PC standar tanpa kesulitan, . Hal ini juga menunjukkan bagaimana konsep-konsep yang diperoleh dapat dengan mudah diperluas ke masalah lain yang diberikan bersifat 2D. Namun demikian, teknik pemrograman yang diberikan pada 2D dapat digunakan untuk masalah yang lebih kompleks untuk permasalahan di 3D sebagaimana disajikan oleh Silvester dan Ferrari [23]. Lembaga pendidikan dengan sumber daya keuangan yang terbatas dapat mengambil manfaat dari metodologi yang diberikan, karena cukup menggunakan OCTAVE yang mana perintah-perintah yang diberikan dalam MATLAB masih bisa digunakan tanpa kecuali, tidak memerlukan tambahan apapun bahkan pembangkit mesh sekalipun). Materi yang disajikan dalam buklik ini mungkin juga berguna untuk para peneliti pemula yang belum mengenal FEM.

Sebagaimana disampaikan di kata pengantar, buklik ini tujuan utamanya adalah tutorial terkait FEM, khususnya untuk menyelesaikan persamaan Helmholtz, dan implementasinya dalam MATLAB/OCTAVE. Beberapa hal yang dapat dilakukan sebagai lanjutan dari tulisan ini :

- Pengembangan lanjutan menjadi program terintegrasi untuk menyelesaikan model yang menggunakan Persamaan Helmholtz, maupun persamaan Yukawa (modified Helmholtz) yang muncul di bidang ilmu lainnya.

- Implementasi PLM yang lebih 'rigorous', terutama untuk geometri bangun tak beraturan yang ditemui di bidang lain [31].

- Pada Alberty dkk [1], disajikan implementasi FEM 3D dalam MATLAB, karenanya untuk geometri 3D sederhana dengan memanfaatkan buku Silvester dan Ferrari [23], dengan mudah diperluas aplikasinya termasuk syarat batas penyerap.

- Juga tidak sulit memperluas buklik ini yang membahas persamaan Helmholtz skalar untuk menyelesaikan persamaan Helmholtz vektorial, dengan memanfaatkan hasil [2]. 


\section{Bibliografi}

[1] Alberty, Jochen and Carstensen, Carsten and Funken, Stefan A, 1999, Remarks around 50 lines of Matlab: short finite element implementation, Numerical Algorithms, 20, 2-3, 117-137

[2] Anjam, I. and Valdman, J., 2015. Fast MATLAB assembly of FEM matrices in 2D and 3D: Edge elements. Applied Mathematics and Computation, 267, pp.252-263.

[3] Babuska, Ihlenburg,Paik, Sauer, 1995, A Generalized Finite Element Method for solving the Helmholtz equation in two dimension with minimal Pollution, Comp.Meth.Appl.Mech.Eng., V128,3-4, pp 325-359.

[4] Bulyshev AE, Semenov SY, Souvorov AE, Svenson RH, Nazarov AG, Sizov YE, Tatsis GP. Computational modeling of three-dimensional microwave tomography of breast cancer. IEEE Transactions on Biomedical Engineering. 2001 Sep;48(9):1053-6.

[5] Cho, H.K. and Han, J., 2012. Numerical study of opto-fluidic ring resonators for biosensor applications. Sensors, 12(10), pp.14144-14157.

[6] Christensen, D. and Fowers, D., 1996. Modeling SPR sensors with the finitedifference time-domain method. Biosensors and Bioelectronics, 11(6-7), pp.677684.

[7] El-Toukhy, Y.M., Hussein, M., Hameed, M.F.O., Heikal, A.M., Abd-Elrazzak, M.M. and Obayya, S.S.A., 2016. Optimized tapered dipole nanoantenna as efficient energy harvester. Optics Express, 24(14), pp.A1107-A1122.

[8] El-Toukhy, Y.M., Hussein, M., Hameed, M.F.O. and Obayya, S.S.A., 2018. Characterization of asymmetric tapered dipole nanoantenna for energy harvesting applications. Plasmonics, 13(2), pp.503-510.

[9] El-Toukhy, Y.M., Heikal, A.M., Hameed, M.F.O., Abd-Elrazzak, M.M. and Obayya, S.S.A., 2016, March. Optimization of nanoantenna for solar energy harvesting based on particle swarm technique. In Wireless Information Technology and Systems (ICWITS) and Applied Computational Electromagnetics (ACES), 2016 IEEE/ACES International Conference on (pp. 1-2). IEEE.

[10] K. Foster, Retaking the field an old computational favourite is overhauled, IEEE Spectrum, July (2004), 5455.

[11] Funken, S., Praetorius, D. and Wissgott, P., 2011. Efficient implementation of adaptive P1-FEM in Matlab. Computational Methods in Applied Mathematics Comput. Methods Appl. Math., 11(4), pp.460-490.

[12] A. K. Ghatak and K. Thyagarajan, Optical Electronics (Cambridge University Press, Cambridge, 1989). 
[13] Haldar, M.K., 2006. Introducing the Finite Element Method in electromagnetics to undergraduates using MATLAB. International journal of electrical engineering education, 43(3), pp.232-244.

[14] S. R. H. Hoole, Computer-Aided Design of Electromagnetic Devices (Elsevier, New York, 1989).

[15] Lopato, P.,Chady, T., Sikora, R.,Gratkowski, S \& Ziolkowski,M., 2013, Full wave numerical modelling of terahertz systems for nondestructive evaluation of dielectric structures, COMPEL-The international journal for computation and mathematics in electrical and electronic engineering, v323, 736-749.

[16] J. Lu and D. V. Thiel, Computational and visual electromagnetics using an integrated programming language for undergraduate engineering students, IEEE Trans. Magnetics, 36 (2000), 10001003

[17] Luo, Z., Suyama, T., Xu, X. and Okuno, Y., 2011. A grating-based plasmon biosensor with high resolution. Progress In Electromagnetics Research, 118, pp.527539

[18] Negara, T.P., Alatas, H., Garnadi, A.D. and Nurdiati, S., 2014. Transmission characteristics of a microscale dielectric slab waveguide device with a deep groove and an embedded metallodielectric grating at low terahertz frequency. OptikInternational Journal for Light and Electron Optics, 125(13), pp.3134-3137.

[19] Persson, P.O. and Strang, G., 2004. A simple mesh generator in MATLAB. SIAM review, 46(2), pp.329-345.

[20] S. Ramo, J. R. Whinnery and T. Van Duzer, Fields and Waves in Communication Electronics (John Wiley, New York, 1994).

[21] S. Selleri, A MATLAB experimental framework for electromagnetic education, IEEE Antennas and Propagat. Mag., 45 (2003), 8590.

[22] S. Selleri, A MATLAB application programmer interface for educational electromagnetics in Antennas and Propagat. Soc. Symp, 2227 June, 2003.

[23] P. P. Silvester and R. L. Ferrari, Finite Elements for Electrical Engineers (Cambridge University Press, Cambridge, 1990).

[24] Singh, V. and Kumar, D., 2009. Theoretical modeling of a metal-clad planar waveguide based biosensors for the detection of pseudomonas-like bacteria. Progress In Electromagnetics Research, 6, pp.167-184.

[25] Sumantyo,JTS., Ito,K., Rahardjo, ET., Saito, K., 2004, Metoda Beda Hingga Kawasan Waktu, Penerbit ITB

[26] Sumantyo,JTS \& Ito,K, 2004, Metoda moment untuk analisa Antena, Penerbit ITB

[27] L. Y. Tio, A. A. P. Gibson, B. M. Dillon and L. E. Davis, Weak form finite element formulation for Helmholtz equation, Int. J. Elect. Enging. Educ., 41 (2004), 19.

[28] Wang, J., Mu, J-Q., Ma, N., and Ma, M-L.,2017, Simulation design of a subwavelength Fano-photonic ring resonator pressure sensor based on Finite Element Method, Optik-International Journal for Light and Electron Optics, 137, 195-202

[29] Wei, E.I., Choy, W.C. and Chew, W.C., 2010. A comprehensive study for the plasmonic thin-film solar cell with periodic structure. Optics express, 18(6), pp.59936007. 
30] Yan, S., Krantz, J., Forberich, K., Pflaum, C. and Brabec, C.J., 2013. Numerical simulation of light propagation in silver nanowire films using time-harmonic inverse iterative method. Journal of Applied Physics, 113(15), p.154303.

[31] Zschiedrich, L., Klose, R., Schdle, A. and Schmidt, F., 2006. A new finite element realization of the perfectly matched layer method for Helmholtz scattering problems on polygonal domains in two dimensions. Journal of Computational and applied mathematics, 188(1), pp.12-32. 


\title{
${ }_{90} \mathrm{Bab} 5$
}

\section{OCTAVE SINGKAT*}

\author{
OCTAVE merupakan program interaktif yang merdeka dan opensource untuk kompu- \\ tasi matriks. OCTAVE dikembangkan sebagai alternatif dari produk komersial popu- \\ ler MATLAB. Kini, OCTAVE dikembangkan secara kolaboratif dalam bentuk konsorsium. \\ Dari homepage tersebut, softwarenya dapat diunduh, juga dapat ditinjau berbagai \\ tambahan yang disumbangkan pengguna. \\ OCTAVE mulai banyak digunakan sebagai lingkungan kerja penyelesaian masalah \\ (Problem Solving Enviroments) di dunia penelitian bidang rekayasa dan industri. Dan \\ kini mulai banyak digunakan sebagai wahana pembelajaran. \\ Sejumlah buku pengajaran Aljabar Linear mempergunakan MATLAB sebagai waha- \\ na pembelajaran. Tidak terlalu sulit bagi pengguna OCTAVE untuk merubahnya ke \\ lingkungan yang diperlukan.
}

\section{Elemen Data Dasar.}

Elemen dasar yang digunakan OCTAVE adalah matriks. Saat pengguna membangkitkan matriks, pengguna dengan cepat dapat melakukan perhitungan yang cukup canggih dengan pemrograman seminimum mungkin.

Membentuk matriks dalam OCTAVE sangatlah mudah. Misalnya untuk membangkitkan matriks berikut :

$$
\left(\begin{array}{llll}
1 & 2 & 3 & 4 \\
5 & 6 & 7 & 8 \\
9 & 10 & 11 & 12 \\
13 & 14 & 15 & 16
\end{array}\right)
$$

dengan mudah dapat diketik hal berikut ini :

$A=\left[\begin{array}{lllllllllllllllllll}1 & 2 & 3 & 4 & ; & 5 & 6 & 7 & 8 & ; & 9 & 10 & 11 & 12 & ; & 13 & 14 & 15 & 16\end{array}\right]$

atau dapat pula diketik dengan cara baris demi baris :

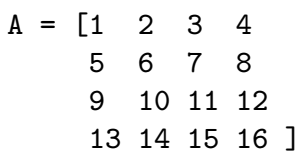


Vektor baris dengan jarak sama dengan mudah dibangkitkan dalam OCTAVE mempergunakan operasi : . Perintah $\mathrm{x}=3: 8$ akan membangkitkan sebuah vektor dengan entri bilangan bulat dari 3 hingga 8 dalam OCTAVE :

$\mathrm{x}=3: 8$

yang hasilnya sama saja kalau kita mengetikkan dalam OCTAVE :

$\mathrm{x}=\left[\begin{array}{llllll}3 & 4 & 5 & 6 & 7 & 8\end{array}\right]$

Tidak hanya jarak teratur sebesar 1 saja yang dapat dibangkitkan seperti ini. Misalnya,

$\mathrm{x}=0.0: 0.25: 1.0$

yang hasilnya sama dengan mengetikkan :

$\mathrm{x}=\left[\begin{array}{lllll}0.0 & 0.25 & 0.5 & 0.75 & 1.0\end{array}\right]$

\section{Submatriks}

Untuk merujuk pada kolom atau baris dari matriks dengan mudah diperoleh. Misalnya kita hendak merujuk pada baris ke-4 dari matriks A, dapat kita perintahkan dengan cara :

baris_4 = A $(4,:)$

Maka OCTAVE akan merespons :

baris_4 =

13141516

tanda : pada A(4,:) menyatakan seluruh indeks kolom. Begitu pula untuk merujuk pada kolom, misalnya kolom ke-3, kita berikan perintah :

kolom_3 $=A(:, 3)$

Maka OCTAVE akan merespons :

kolom_3 =

3

7

11

15

Dalam OCTAVE diberikan kemudahan untuk akses sub-matriks. Misalnya, kita hendak mengambil submatriks di baris-1 sampai 3, dan kolom 2 sampai 4, kita berikan perintah berikut ini :

A_13_24 = A $(1: 3,2: 4)$

Maka OCTAVE akan merespons :

A_13_24 =

$\begin{array}{lll}2 & 3 & 4\end{array}$

$\begin{array}{lll}6 & 7 & 8\end{array}$

$\begin{array}{lll}10 & 11 & 12\end{array}$ 


\section{Membangkitkan Matriks.}

Dengan mempergunakan fungsi OCTAVE yang sudah jadi, pengguna dengan mudah membangkitkan matriks berdasarkan formula yang diinginkan. Misalnya, perintah

$B=\operatorname{rand}(4,4)$

akan membangkitkan matriks B berukuran $4 \times 4$ yang entrinya merupakan bilangan acak di selang $[0,1]$. Fungsi lainnya yang dapat digunakan untuk membangkitkan matriks antara lain eye, zeros, ones dan toeplitz. Untuk membangkitkan matriks segitiga dan diagona tersedia fungsi triu, tril, dan diag .

Perintah membangun matriks dapat digunakan untuk mengkonstruksi matriks berdasarkan partisi. Misalnya, perintah OCTAVE

$E=[$ eye $(2,2)$ ones $(2,3) ; \operatorname{zeros}(2,2)[1: 3 ; 3:-1: 1]]$

Sehingga akan dibangkitkan matriks :

$$
\mathrm{E}=\left[\begin{array}{lllll}
1 & 0 & 1 & 1 & 1 \\
0 & 1 & 1 & 1 & 1 \\
0 & 0 & 1 & 2 & 3 \\
0 & 0 & 3 & 2 & 1
\end{array}\right]
$$

\section{Aritmetika Matriks}

Aritmetika matriks dalam OCTAVE cukup sederhana. Perkalian dua buah matriks A dan B dengan mudah dilakukan dengan menuliskan perintah A*B. Penjumlahan dan selisih dua buah matriks pula mudah dilakukan dengan memberikan perintah sesederhana berikut ini A+B dan A-B. Sedangkan transposisi matriks dengan mudah dapat menggunakan perintah :

$A^{\prime}$

Jika c merupakan vektor (kolom) di $\mathrm{R}^{4}$, maka solusi sistem persamaan linear $\mathbf{A x}=\mathbf{c}$ dapat dihitung dengan memberikan perintah :

$\mathrm{x}=\mathrm{A} \backslash \mathrm{C}$

\section{Fungsi OCTAVE}

Untuk menghitung nilai eigen dari matriks segi A, cukup mengetikkan spec(A). Sementara vektor eigen dan nilai eigen dapat diperoleh dengan memberikan perintah :

$[\mathrm{X}$ D $]=\operatorname{spec}(\mathrm{A})$

dengan matriks $D$ berupa matriks diagonal yang pada diagonalnya memuat nilai eigen matrix $A$, sedangkan matriks $X$ yang kolomnya merupakan vektor eigen matriks $A$ yang berkaitan dengan nilai eigen pada diagonal $D$.

Begitu pula beberapa fungsi untuk matriks tersedia misalnya determinan, invers, bilangan kondisi, norm dan rank sebuah matriks yang perintahnya hanya terdiri dari perintah satu-kata. Faktorisasi matriks seperti LU, QR, Cholesky, dekomposisi Schur dan dekomposisis nilai singular juga dapat dihitung dengan perintah satu-kata. Misalnya, perintah

$[Q R]=\operatorname{qr}(A)$

akan menghasilkan matriks ortogonal $Q$ dan matriks segi tiga atas $R$, dengan ukuran yang sama dengan $A$, sehingga : $A=Q * R$. 


\section{Ciri pemrograman}

OCTAVE memiliki semua struktur kendali pemrograman sebagaimana ditemukan di pemrograman bahasa tingkat tinggi seperti for, while, dan if. Hal ini memungkinkan pengguna untuk menulis program OCTAVE berdasarkan kebutuhan mereka dan menggenapkan fungsi OCTAVE yang ada. Beberapa hal yang perlu di catat antara lain, OCTAVE akan mencetak setiap perintah kecuali bila pada akhir perintah tersebut diberikan titik koma. Bila mempergunakan perintah berulang, sebaiknya dalam setiap pengulangan perintahnya diakhiri dengan titik koma, untuk menghindari hasil antara diperlihatkan di layar.

\section{OCTAVE file.}

Pengguna dapat memperluas fungsionalitas OCTAVE dengan menambahkan program baru yang dibutuhkannya. Program di OCTAVE dituliskan dalam sebuah file yaitu .m dan sering dirujuk sebagai OCTAVE m-file.

Script files ialah file yang isinya merupakan serangkaian perintah OCTAVE . Semua variable dalam file ini bersifat global, sehingga nilai dari variabel tersebut akan berubah setiap script ini dijalankan. Sebagai contoh, misalkan seseorang ingin menghitung nolitas dari sebuah matriks, maka disusunlah sebuah script file dengan nama nolitas.m yang isinya ialah perintah berikut ini :

[n_baris n_kolom] = $\operatorname{size}(A)$;

nol_dim $=$ n_kolom $-\operatorname{rank}(A)$;

Dengan mengeksekusi perintah nolitas akan mengakibatkan kedua baris perintah di atas akan dilaksanakan. Salah satu kelemahan untuk menentukan nolitas seperti di atas ialah, matriksnya selalu bernama A dan nilai variabel n_baris dan n_kolom selalu berubah manakala perintah tersebut dilaksanakan. Sebagai pilihan, dapat digunakan function file.

Sebuah function file dimulai dengan sebuah deklarasi funsional yang berbentuk :

$[\operatorname{oarg} 1, \operatorname{oarg} 2, \ldots$, oargj $]=f \_n a m a($ inarg 1, inarg $2, \ldots$, inargk $)$

Semua variabel dalam function file bersifat lokal. Bila function files ini dipanggil, maka hanya variabel output saja yang berubah setiap saat bekerja. Misalnya, disusun sebuah function file dengan nama nolitas.m utuk menghitung nolitas matriks sebagai berikut :

function $\mathrm{k}=\operatorname{nolitas}(\mathrm{A})$

$\%$ perintah nolitas(A) akan menghitung dimensi

$\%$ ruang nol dari $A$.

[n_baris, n_kolom] $=\operatorname{size}(A)$;

$\mathrm{k}=\mathrm{n} \_\mathrm{kolom}-\operatorname{rank}(\mathrm{A})$;

Baris dengan tanda \% merupakan komentar dan tidak akan dieksekusi. Bila function files tersebut disimpan, fungsi tersebut dapat dipakai sebagaimana perintah OCTAVE biasa. Misalnya, jika kita tetapkan

$$
\text { Test_matriks }=\left[\begin{array}{lllllllll}
1 & 2 & 3 ; & 4 & 5 & 6 ; & 7 & 8 & 9
\end{array}\right]
$$

kemudian kita gunakan perintah :

$$
\mathrm{n}=\text { nolitas (Test_matriks) }
$$

OCTAVE akan memberikan jawaban : $\mathrm{n}=1$. 
${ }_{1122}$ Fungsi pembangkit matriks.

Sejumlah fungsi pembangkit matriks yang cukup bermanfaat antara lain :

$\begin{array}{ll}\text { eye } & \text { matriks identitas } \\ \text { zeros } & \text { matriks nol } \\ \text { ones } & \text { matriks satu } \\ \text { diag } & \text { lihat di bawah } \\ \text { triu } & \text { bagian segi tiga atas sebuah matriks } \\ \text { tril } & \text { bagian segi tiga bawah sebuah matriks } \\ \text { rand } & \text { matriks yang dibangkitkan secara acak } \\ \text { toeplitz } & \text { see help toeplitz }\end{array}$

\author{
menghasilan sebuah matriks nol berukuran $n$-kali- $n$; jika $A$ sebuah matriks, maka \\ zeros (A) menghasilan sebuah matriks nol berukuran sama dengan ukuran A. \\ Jika $\mathrm{x}$ sebuah vektor, diag(x) ialah sebuah matriks diagonal dengan $\mathrm{x}$ sepanjang \\ diagonalnya; jika $A$ sebuah matriks segi, maka diag(A) ialah sebuah vektor yang isinya \\ diagonal dari A. Lalu apakah diag(diag(A))? Cobalah. \\ Matriks dapat dibangun dari blok. Misalnya, jika $A$ sebuah matriks berukuran \\ 3-kali-3, maka

$$
\mathrm{B}=[\mathrm{A}, \operatorname{zeros}(3,2) ; \operatorname{zeros}(2,3), \text { eye }(2,2)]
$$

1132 akan merupakan sebuah matriks tertentu berukuran 5-kali-5. 


\section{LAMPIRAN}




\section{LAMPIRAN 1}

1135

Script MATLAB lengkap untuk kasus 1,

load koordinat 1 .dat; koordinat $1(:, 1)=[]$; \%koordinat

load elemen1.dat; elemen $1(:, 1)=[] ; \%$ elemen hingga segitiga

load deltaomega.dat; deltaomega $(:, 1)=[]$;

koordinat $=$ koordinat 1 ;

elemen = elemen 1 ;

NodeBebas $=$ setdiff $(1:$ size $($ koordinat, 1$)$, unique (deltaomega $))$;

$A=\operatorname{sparse}(\operatorname{size}($ koordinat, 1$), \operatorname{size}($ koordinat, 1$))$;

$\mathrm{b}=\operatorname{sparse}(\operatorname{size}($ koordinat, 1$), 1)$;

$\%$ 1. menyusun matriks A1

\% dengan memanggil fungsi stima

for $\mathrm{i}=1: \mathbf{s i z e}($ elemen, 1$)$

$\mathrm{A}(\operatorname{elemen}(\mathrm{i},:), \operatorname{elemen}(\mathrm{i},:))=\ldots$

$\mathrm{A}(\operatorname{elemen}(\mathrm{i},:)$, elemen $(\mathrm{i},:)) \ldots$

end

$+\operatorname{stima}($ koordinat $(\operatorname{elemen}(\mathrm{i},:),:))$;

\% 2. menyusun matriks A2

for $\mathrm{i}=1: \mathbf{s i z e}($ elemen, 1$)$

$\mathrm{A}(\operatorname{elemen}(\mathrm{i},:)$, elemen $(\mathrm{i},:))=\mathrm{A}(\operatorname{elemen}(\mathrm{i},:), \operatorname{elemen}(\mathrm{i},:))+\ldots$ $\left.\operatorname{det}\left([\text { ones }(1,3) ; \text { koordinat (elemen }(\mathrm{i},:),:)^{\prime}\right]\right) * \ldots$ $(\operatorname{diag}($ ones $(3,1))+$ ones $(3)) * \ldots$

end k0 ( $\operatorname{sum}($ koordinat $(\operatorname{elemen}(\mathrm{i},:),:$ ) ) / 3$) / 24$;

$\mathrm{u}=\operatorname{sparse}(\mathbf{s i z e}($ koordinat, 1$), 1)$;

$\mathrm{u}($ unique $($ deltaomega $))=\operatorname{deltaO}($ koordinat $($ unique $($ deltaomega $),:))$;

$\mathrm{b}=\mathrm{b}-\mathrm{A} * \mathrm{u}$

\% 3. Komputasi solusi

$\mathrm{u}($ NodeBebas $)=\mathrm{A}($ NodeBebas, NodeBebas $) \backslash \mathrm{b}($ NodeBebas $)$;

\% 4. Grafika

show (elemen, [], koordinat, full (u));

xlabel ('x'); ylabel ('y'); zlabel ('u'); 


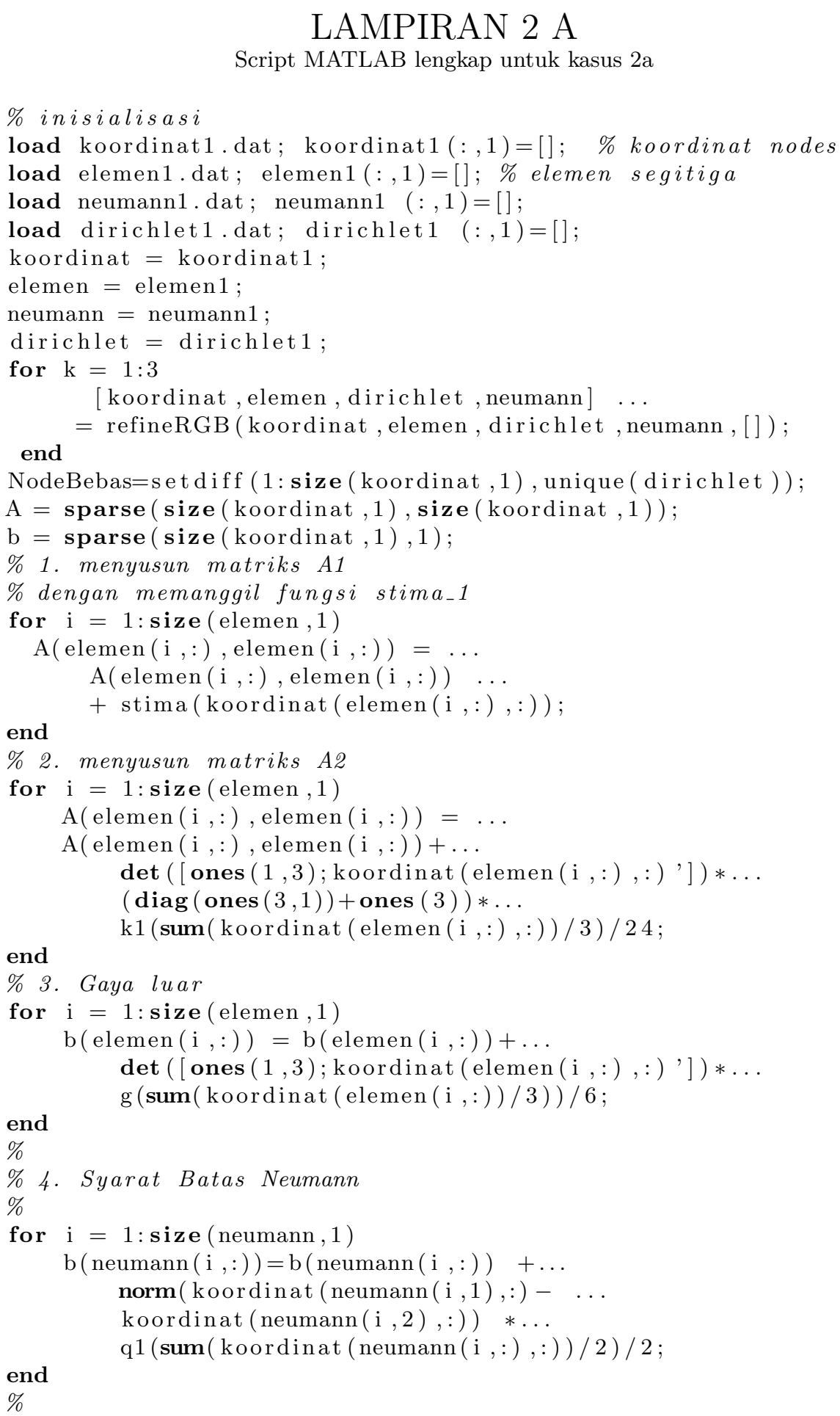




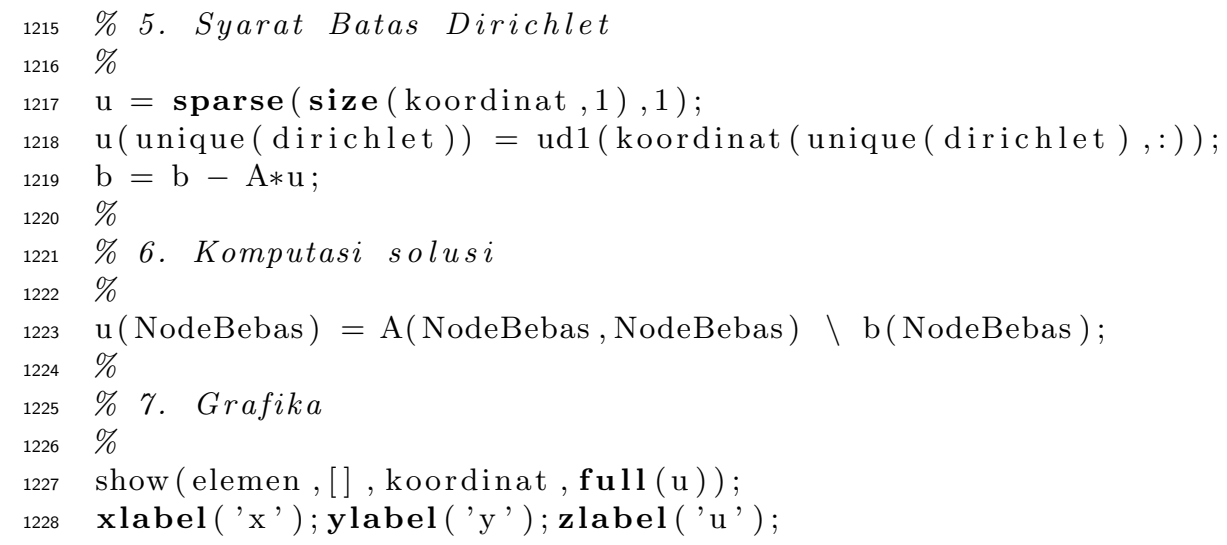




\section{LAMPIRAN 2 B}

Script MATLAB lengkap untuk kasus 2b

load koordinat 2 .dat; koordinat $2(:, 1)=[] ; \%$ koordinat node

load elemen 2 .dat; elemen $2(:, 1)=[] ; \%$ daftar elemen segitiga

load neumann3.dat; neumann3 $(:, 1)=[]$;

load dirichlet 3 .dat; dirichlet $3(:, 1)=[]$;

koordinat=koordinat 2 ;

elemen=elemen 2 ;

neumann $=$ neumann 3 ;

dirichlet $=$ dirichlet 3 ;

for $\mathrm{k}=1: 5$

[koordinat, elemen, dirichlet, neumann] ...

end

$=$ refineRGB (koordinat, elemen, dirichlet, neumann, [] );

NodeBebas=setdiff $(1$ : size (koordinat, 1$)$, unique (dirichlet) $)$;

$\mathrm{A}=\operatorname{sparse}(\operatorname{size}($ koordinat, 1$)$, size $($ koordinat, 1$)) ;$

$\mathrm{b}=\operatorname{sparse}(\operatorname{size}($ koordinat, 1$), 1) ;$

\% 1. menyusun matriks A1

$\%$ dengan memanggil fungsi stima_1

for $\mathrm{i}=1$ : size(elemen, 1$)$

$\mathrm{A}(\operatorname{elemen}(\mathrm{i},:)$, elemen $(\mathrm{i},:))=\ldots$

A(elemen $(\mathrm{i},:)$, elemen $(\mathrm{i},:)) \ldots$

$+\operatorname{stima}($ koordinat $($ elemen $(i,:),:))$;

end

\% 2. menyusun matriks A2

for $\mathrm{i}=1$ : size(elemen, 1$)$

$\mathrm{A}(\operatorname{elemen}(\mathrm{i},:)$, elemen $(\mathrm{i},:))=\ldots$

$\mathrm{A}(\operatorname{elemen}(\mathrm{i},:)$, elemen $(\mathrm{i},:))+\ldots$

$\operatorname{det}\left(\left[\right.\right.$ ones $(1,3) ;$ koordinat $\left.\left.\left(\operatorname{elemen}(\mathrm{i},:)^{\prime},:\right)^{\prime}\right]\right) * \ldots$

$(\operatorname{diag}(\operatorname{ones}(3,1))+$ ones $(3)) * \ldots$

end

k1 (sum(koordinat (elemen $(\mathrm{i},:),:$ ) ) / 3$) / 24$;

\% 3. Gaya luar

for $\mathrm{i}=1: \operatorname{size}($ elemen, 1$)$

$\mathrm{b}(\operatorname{elemen}(\mathrm{i},:))=\mathrm{b}(\operatorname{elemen}(\mathrm{i},:))+\ldots$

$\operatorname{det}\left(\left[\right.\right.$ ones $(1,3) ;$ koordinat $\left.\left.\left.\left(\text { elemen }(\mathrm{i},:)^{\prime},:\right)^{\prime}\right]\right]\right) * \ldots$

end $\mathrm{g}(\operatorname{sum}($ koordinat $($ elemen $(\mathrm{i},:)) / 3)) / 6$;

$\%$ 4. Syarat Batas Neumann

for $\mathrm{i}=1: \operatorname{size}($ neumann, 1$)$

$\mathrm{b}(\operatorname{neumann}(\mathrm{i},:))=\mathrm{b}($ neumann $(\mathrm{i},::))+\ldots$ $\operatorname{norm}($ koordinat (neumann $(\mathrm{i}, 1),:$ ) - $\ldots$ koordinat (neumann $(\mathrm{i}, 2),:)) * \ldots$

end q1 (sum(koordinat (neumann $(\mathrm{i},:),:$ ) ) / 2)/2;

\% 5. Syarat Batas Dirichlet

$\mathrm{u}=\operatorname{sparse}(\operatorname{size}($ koordinat, 1$), 1)$;

$\mathrm{u}($ unique $($ dirichlet $))=\operatorname{ud} 1($ koordinat $($ unique $($ dirichlet $),:))$;

$\mathrm{b}=\mathrm{b}-\mathrm{A} * \mathrm{u}$; 


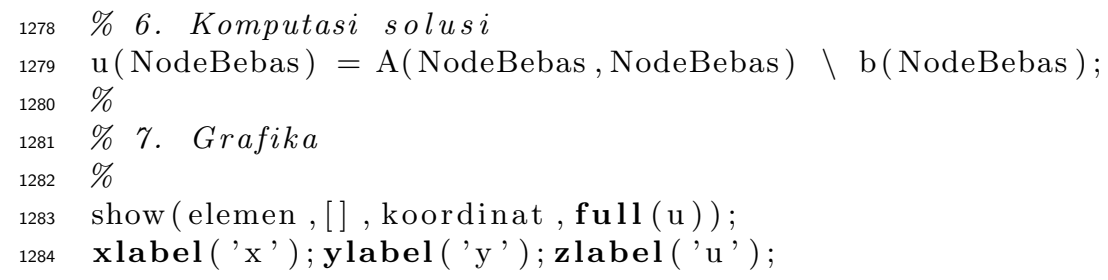




\section{LAMPIRAN $2 \mathrm{C}$}

Script MATLAB lengkap untuk kasus 2c

load koordinat 3 .dat; koordinat $3(:, 1)=[] ; \quad \%$ koordinat

load elemen3.dat; elemen $3(:, 1)=[] ; \%$ elemen segitiga

load neumann4.dat; neumann $4(:, 1)=[]$;

load dirichlet 4 .dat; dirichlet $4(:, 1)=[]$;

koordinat $=$ koordinat 3 ;

elemen=elemen 3 ;

neumann = neumann 4 ;

dirichlet $=$ dirichlet 4 ;

for $\mathrm{k}=1: 4$

[koordinat, elemen, dirichlet, neumann] ...

end

$=$ refineRGB (koordinat, elemen, dirichlet, neumann, [] );

NodeBebas $=$ setdiff $(1: \operatorname{size}($ koordinat, 1$)$, unique (dirichlet $))$;

$\mathrm{A}=\operatorname{sparse}(\mathbf{s i z e}($ koordinat, 1$), \mathbf{s i z e}($ koordinat, 1$))$;

$\mathrm{b}=\operatorname{sparse}(\mathbf{s i z e}($ koordinat, 1$), 1)$;

$\%$ 1. menyusun matriks A1

$\%$ dengan memanggil fungsi stima-1

for $\mathrm{i}=1: \mathbf{s i z e}($ elemen, 1$)$

$\mathrm{A}(\operatorname{elemen}(\mathrm{i},:)$, elemen $(\mathrm{i},:))=\ldots$

A(elemen (i : : ), elemen $(\mathrm{i},:)) \quad \ldots$ end

$+\operatorname{stima}($ koordinat $(\operatorname{elemen}(\mathrm{i},:),:))$;

\% 2. menyusun matriks A2

for $\mathrm{i}=1: \operatorname{size}($ elemen, 1$)$

$\mathrm{A}(\operatorname{elemen}(\mathrm{i},:)$, elemen $(\mathrm{i},:))=\ldots$

$\mathrm{A}(\operatorname{elemen}(\mathrm{i},:)$, elemen $(\mathrm{i},:))+\ldots$

$\operatorname{det}\left(\left[\operatorname{ones}(1,3) ;\right.\right.$ koordinat $\left.\left.(\operatorname{elemen}(\mathrm{i},:),:)^{\prime}\right]\right) * \ldots$

$(\operatorname{diag}($ ones $(3,1))+$ ones $(3)) * \ldots$

end

$\mathrm{k} 2(\operatorname{sum}($ koordinat $(\operatorname{elemen}(\mathrm{i},:),:)) / 3) / 24$;

\% 3. Gaya luar

for $\mathrm{i}=1: \mathbf{s i z e}($ elemen, 1$)$

$\mathrm{b}(\operatorname{elemen}(\mathrm{i},:))=\mathrm{b}(\operatorname{elemen}(\mathrm{i},:))+\ldots$

$\left.\operatorname{det}\left([\operatorname{ones}(1,3) ; \text { koordinat }(\operatorname{elemen}(\mathrm{i},:),:))^{\prime}\right]\right) * \ldots$

end $\mathrm{g}(\operatorname{sum}($ koordinat $(\operatorname{elemen}(\mathrm{i},:)) / 3)) / 6$;

$\%$ 4. Syarat Neumann

for $\mathrm{i}=1: \operatorname{size}($ neumann, 1$)$

$\mathrm{b}(\operatorname{neumann}(\mathrm{i},:))=\mathrm{b}(\operatorname{neumann}(\mathrm{i},:))+\ldots$ $\operatorname{norm}($ koordinat (neumann $(\mathrm{i}, 1),:)-\ldots$ koordinat (neumann (i , 2),: )) $*$...

end q1 (sum $($ koordinat $(\operatorname{neumann}(\mathrm{i},:),:)) / 2) / 2$;

\% 5. Syarat Dirichlet

$\mathrm{u}=\operatorname{sparse}(\operatorname{size}($ koordinat, 1$), 1)$;

$\mathrm{u}($ unique $(\operatorname{dirichlet}))=\mathrm{ud} 3(\operatorname{koordinat}($ unique $(\operatorname{dirichlet}),:))$;

$\mathrm{b}=\mathrm{b}-\mathrm{A} * \mathrm{u}$; 


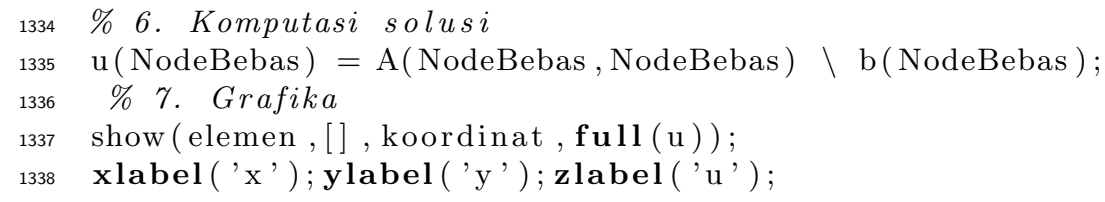




\section{LAMPIRAN 2 D}

Script MATLAB lengkap untuk kasus 2d

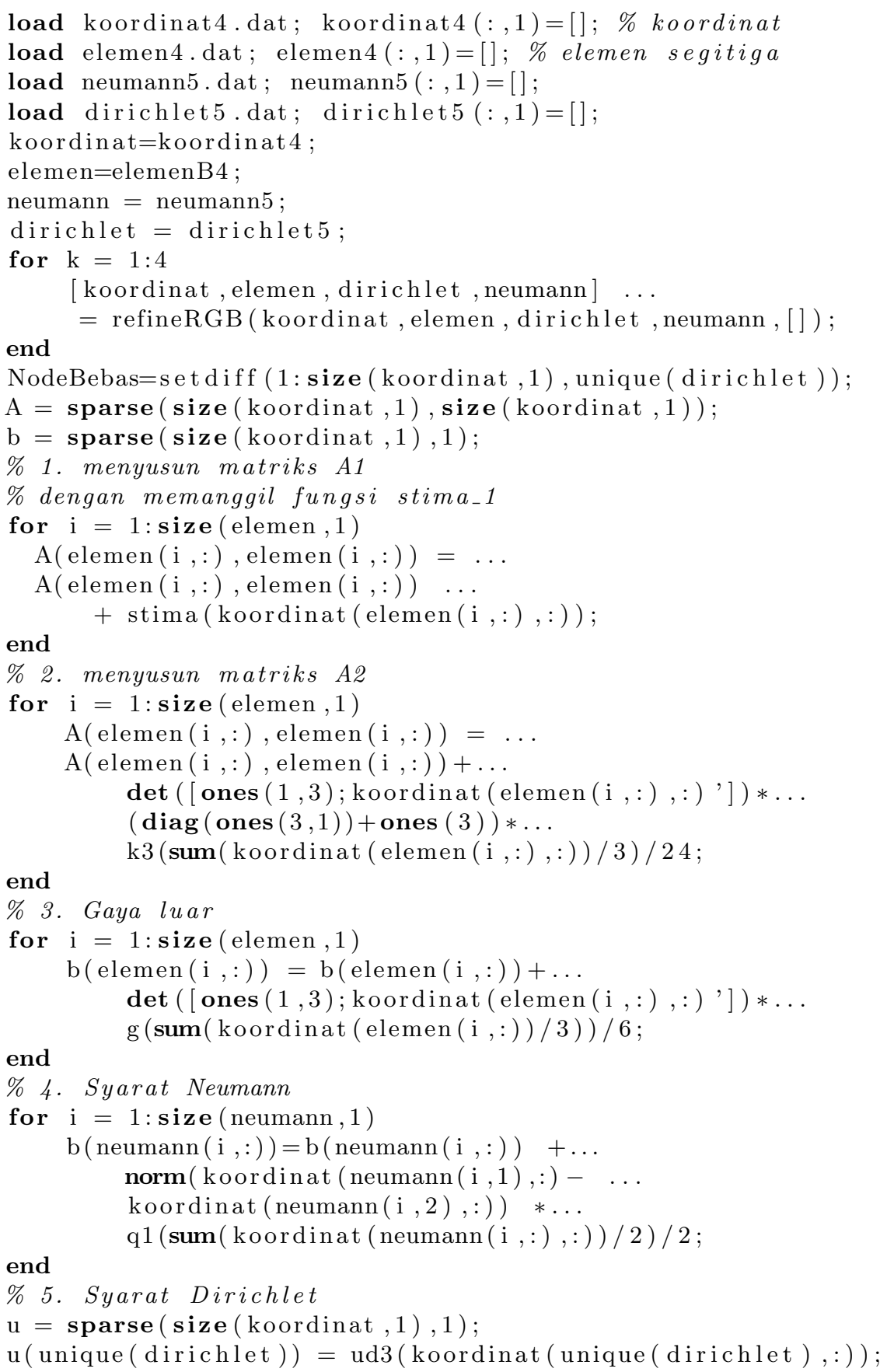




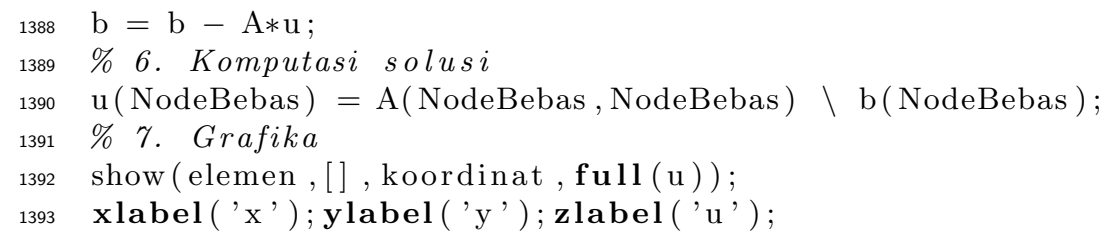


Untuk dapat melakukan pekerjaan secara mandiri membangun grid yang diperlukan, akan ditampilkan diskusi singkat dan penggunaan sederhana menggunakan perangkat Distmesh [19] yang tersedia dengan bebas, dan didiskusikan secara rinci dalam:

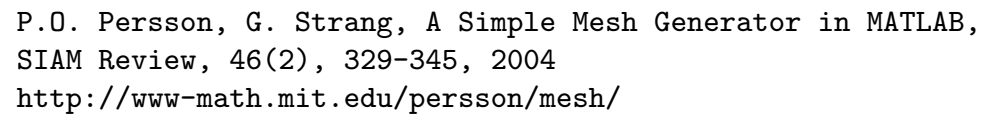

Tulisan ini juga berfungsi menyediakan user guide yang bersifat komprehensif. DistMesh sangat sesuai karena mudah penggunaannya dan permulaan yang baik sebelum bergerak ke arah yang lebih kompleks dan aplikasi yang lebih canggih tanpa perlu ragu menggunakan software pembentuk mesh selanjutnya.

Selanjutnya kami menjelaskan bagaimana DistMesh dapat memproses secara otomatis untuk membentuk mesh 1D dan 2D yang seragam maupun yang tidak seragam. Kami akan memberikan sedikit penggunaan tulisan dan contoh bagaimana menyusun dan mendefinisikan sebuah mesh, bagaimana mendefinisikan tipe batas yang dibutuhkan unuk kondisi batas yang spesifik, menggunakan fungsi jarak untuk menggambarkan geometri, dan bagaimana menyusun sebuah mesh periodik yang sederhana.

\section{B1. Dasar}

Kami menggambarkan mengenai penggunaan DistMesh untuk mendapatkan (VX, VY) dan EToV dibutuhkan untuk menghitung konektivitas dan sebagainya. DistMesh berbasis pada penggunaan fungsi jarak untuk geometri yang spesifik. Dalam hal ini fungsi jarak dapat dikombinasikan dan dimanipulasi untuk menetapkan apakah didalam atau diluar geometri tertentu adalah negatif.

Bentuk umum bagian dari DistMesh adalah:

> function $[p, t]=$ distmeshnd $(f d, f h, h 0, b b o x, p f i x$, varargin $)$;

Argumennya sebagai berikut: 
Input: 6 Variabel berupa

Fd : Fungsi yang menandakan jarak dari masing-masing node ke batas

Fh : Fungsi yang menunjukkan panjang sisi relative untuk semua titik input

HO : Ukuran grid awal, yang menjadikan ukuran grid teraproksimasi untuk grid

Bbox $\quad$ : Box terikat untuk geometri

Pfix : Array dari node-node yang tetap

Varargin : Array optional

Output: dua variabel berupa

$\mathrm{P} \quad$ : Daftar dari vertex, contohnya $\mathrm{VX}=\mathrm{p}(:, 1), \mathrm{VY}=\mathrm{p}(:, 2)$, dan lain lain

$\mathrm{T}$ : Daftar dari elemen, EToV=t

Kemudian perhatikan sebuah contoh pembentukan mesh satu D sederhana pada segmen garis tidak seragam yang dikelompokan pada $x=0$ dalam $\Omega=[-1,1]$. Kami mendefunisikan fungsi jarak yang ditandai sebagai:

$\%$ distance function for a circle about $\mathrm{xc}=0$

> $f d=\operatorname{inline}(\operatorname{abs}(p)-1, p)$;

Dimana $P$ bisa dijadikan koordinat $X$. Pada kasus ini, fungsi jarak bisa dikhususkan melalui sebuah fungsi utama, tapi hal tersebut tidak dibutuhkan. Untuk ukuran grid yang tidak seragam kita harus mengkhususkan sebuah fungsi ukuran elemen yang menggambarkan distribusi relatif melalui domain, sehingga kumpulan didalam fungsi ini tidak menggambarkan ukuran grid yang aktual. Sebagaimana contoh.

\section{$\%$ distribution weight function}

$\gg \mathrm{fh}=\operatorname{inline}(\operatorname{abs}(\mathrm{p}) * 0.075+0.0125, \mathrm{p})$;

Mesh dibentuk melalui bagian:

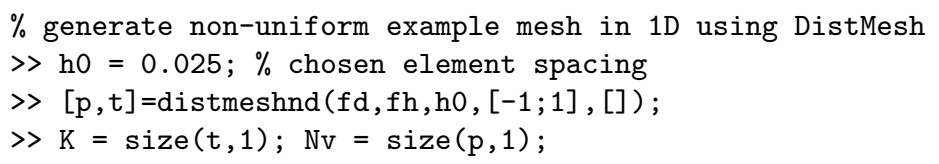

Dua tabel ditunjukan yang secara lengkap mendefinisikan mesh, dan kita bisa menunjukan sejumlah elemen $\mathrm{K}$, dan verteks, $\mathrm{Nv}$, Secara langsung dari ukuran array ini.

Sebuah mesh yang seragam bisa dibentuk melalui fungsi intrinsik bernama huniform, sebagai berikut ini:

$\%$ generate uniform example mesh in 1D using DistMesh

> $[p, t]=$ distmeshnd (fd, @hunif orm, h0, $[-1 ; 1],[]$ ) ;

Node verteks ditambahkan menjadi:

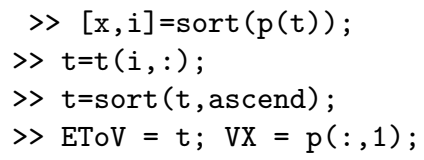


Ini bisa ditunjukan secara langsung pada solver. Langkah sederhana ini dikumpulkan dalam script yang kecil MeshGenDistMesh1D.m.

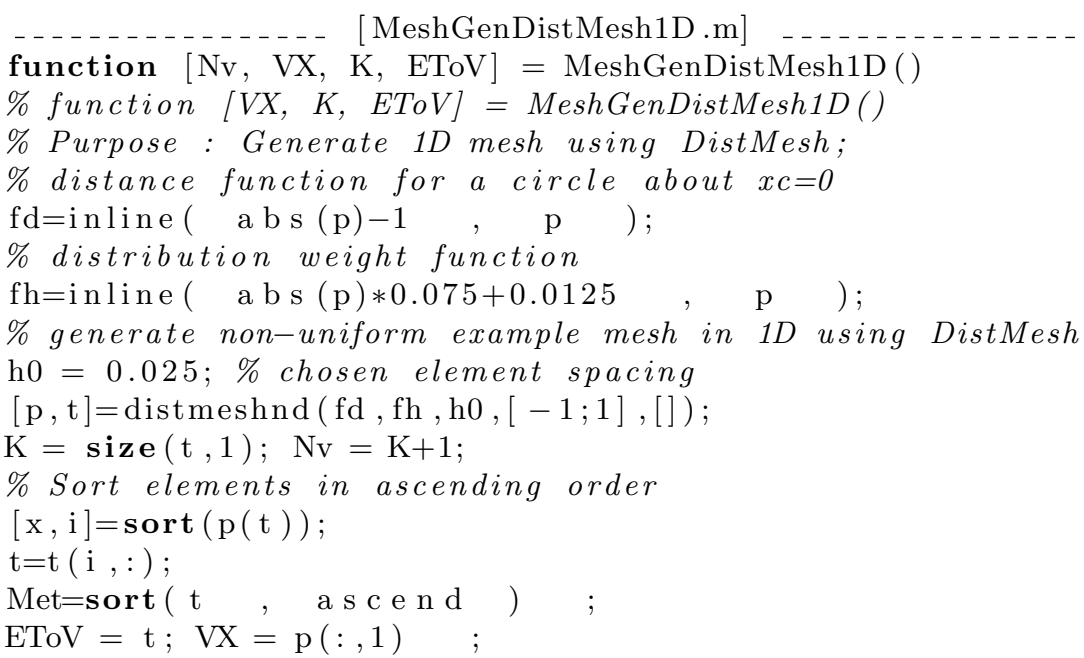

Grid 2D bisa dibentuk dalam cara yang sama. Perhatikan sebagaimana contoh pembentukan grid equidistant dalam sebuah domain melingkar, dikelilingi oleh $[-1,1]^{2}$. Berikutnya outline dibawah kami lanjutkan sebagai :

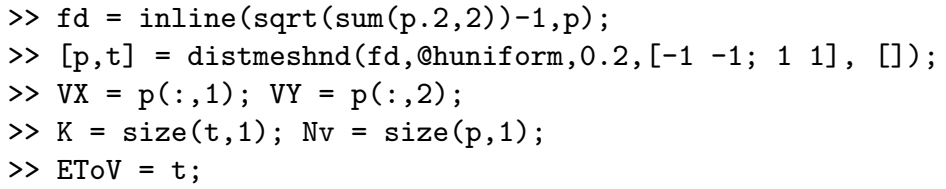

Catatan: Dalam DistMesh tidak menghasilkan susunan elemen vertex yang berlawanan arah jarum jam, untuk itu perlu diperiksa dan dikoreksi semua elemen untuk memastikannya. Contoh:

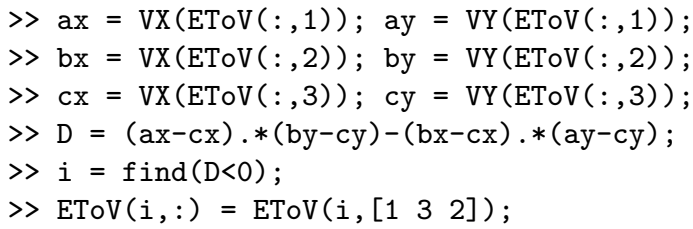

Disini banyak beberapa contoh dalam user guide DistMesh yang bisa menunjukkan daftar dari fungsi yang sederhana; contohnya, untuk membentuk grid persegi panjang seseorang bisa menggunakan:

function $[\mathrm{VX}, \mathrm{VY}, \mathrm{K}, \mathrm{ETOV}]=$ MeshGenDistMesh2D ()

$\%$ function [VX, VY, K, EToV] = MeshGenDistMesh2D ()

$\%$ Purpose : Generate 2D square mesh using DistMesh;

$\%$ By Allan P. Engsig-Karup 


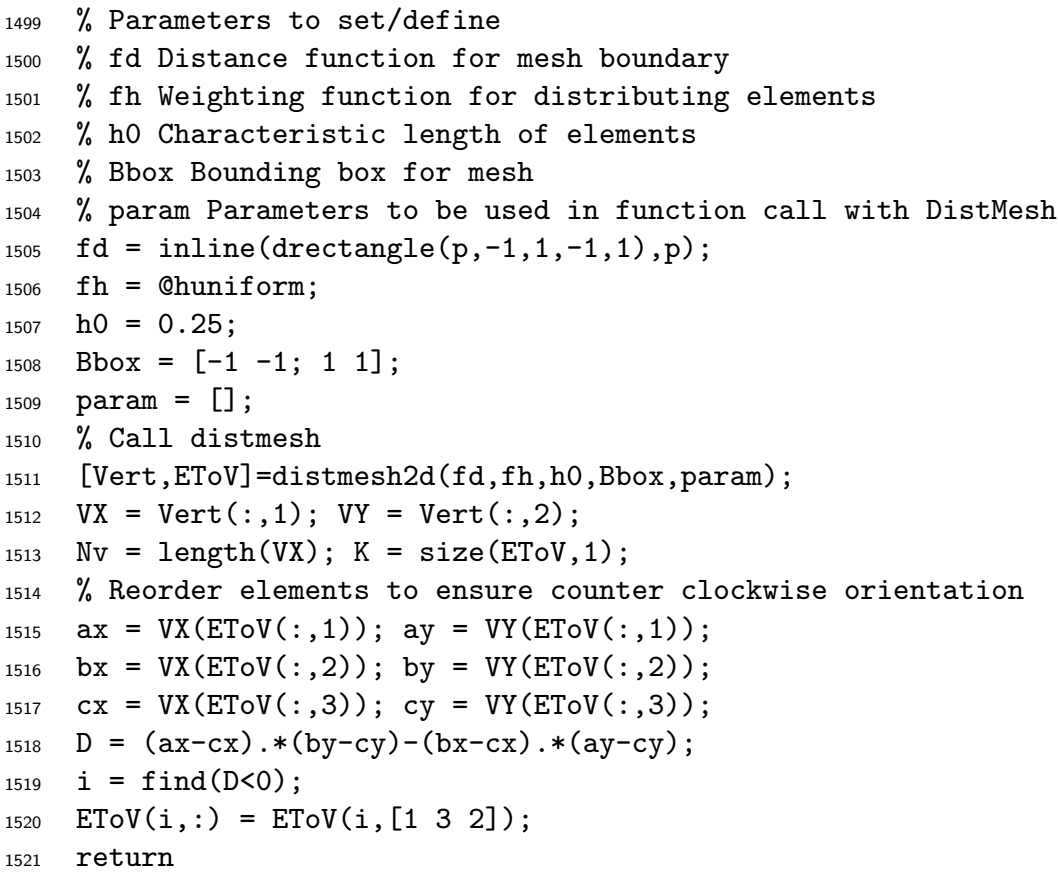

\section{B2. Membentuk Peta Batas}

Terkadang banyak contoh dan grid secara umum ditunjukkan dalam user guide DistMesh; pembentukan peta batas yang khusus untuk menunjukkan kondisi batas yang berbeda dibutuhkan sedikit langkah: Tabel batas untuk semua muka elemen lebih mudah didapatkan dari array EToE sebagai:

> BCType $=\operatorname{int} 8(\operatorname{not}(\mathrm{EToE}))$;

Berikutnya, jika kita ingin membedakan batas yang berbeda, kita membutuhkan cara yang efisien untuk syarat batas yang khusus. Secara konvensional bisa dilakukan dengan fungsi jarak dengan syarat $d=0$ pada batas dan $d<>$ diluar batas. Perhatikan contoh berikut ini. Kita set up sebuah unit lingkaran dengan lubang di bagian tengah sebagai:

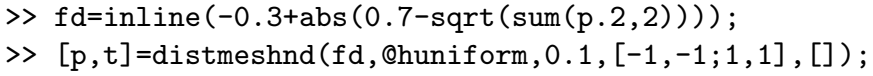

Dengan mudah hanya melalui dua baris perintah pada kode DistMesh. Kita ingin mendefinisikan peta mapI dan map0 yang bisa mengkhususkan kondisi batas yang berbeda di dalam dan diluar batas pada lingkaran berjejari satu satuan dengan bolongan di tengah. Kami catat bahwa fungsi jarak menggambarkan batas secara lengkap (lihat gambar B1)

$\gg$ fd inner=inline $(\operatorname{sqrt}(\operatorname{sum}(\mathrm{p} .2,2))-0.4, \mathrm{p})$;

Penggunaan fungsi ini bisa menentukan daftar indeks dari node vertex pada batas melalui: 


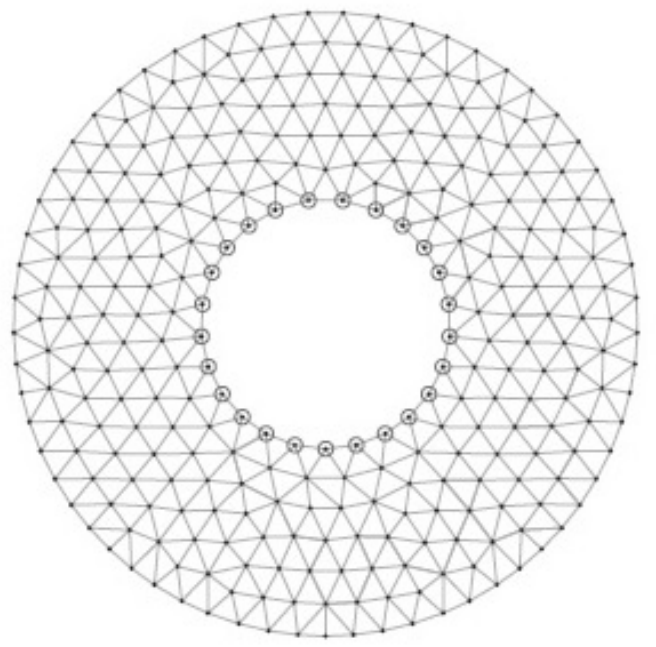

Gambar 5.1: Mesh $\Omega$ berupa cincin

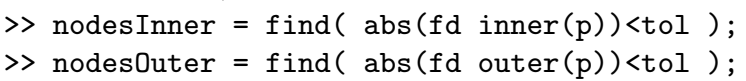

Disini tol adalah toleransi yang diberikan yang dapat diubah bergantung pada grid. Nilai tersebut bisa lebih rendah dibandingkan jarak minimum lokal diantara node-node. Oleh karena itu dianjrkan untuk selalu memeriksa peta batas yang di definisikan. Cara mudah untuk melakukan ini adalah:

$\%$ choose a map to plot

$>$ MAP = nodesInner;

$\%$ show all vertices and circle out map nodes in red

> $\operatorname{plot}(\mathrm{p}(:, 1), \mathrm{p}(:, 2), \mathrm{k} ., \mathrm{p}(\mathrm{MAP}, 1), \mathrm{p}(\mathrm{MAP}, 2), \mathrm{ro})$;

Gambar B.1 Mesh unit lingkaran

Definisikan konstanta:

$>$ In $=1$;

$>$ Out $=2$;

Dengan menggunakan konstanta tersebut untuk memeriksa informasi dalam tabel, BCType, melalui: 


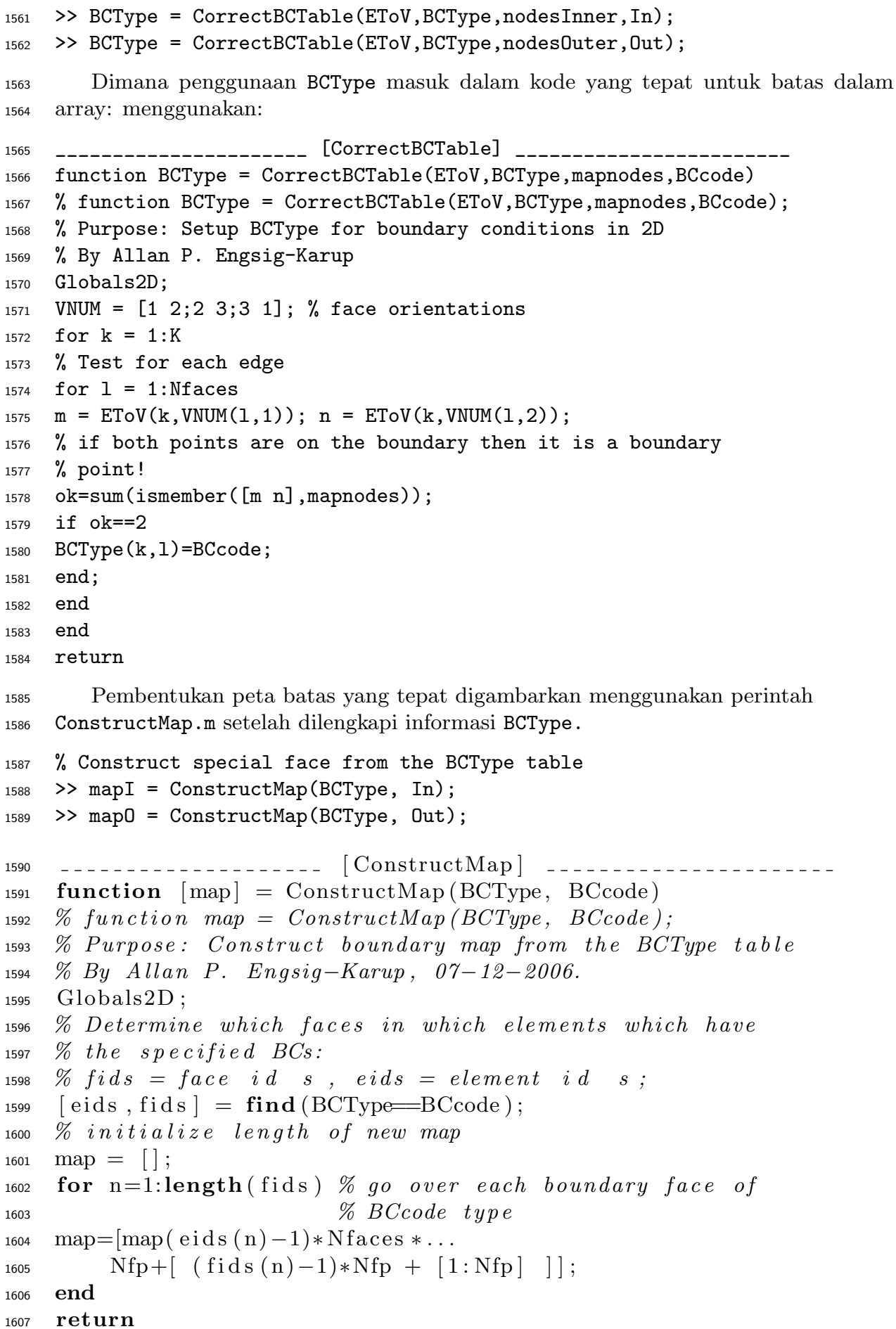




\section{LAMPIRAN 4}

Script MATLAB untuk Utilities

- [1.] Refine mesh [11]

function [coordinates, newElements, varargout] ... $=$ refineRGB (coordinates, elements, varargin $)$

\%refineRGB: local refinement of finite element mesh by \%red-green-blue, refinement, where marked elements are \%red-refined.

$\%$

\% Usage:

$\%$

$\%$ [coordinates, elements, dirichlet,neumann] ...

$\%=$ refine $R G B$ (coordinates, elements, dirichlet,...

$\%$ neumann, marked)

$\%$

$\%$ refine $R G B$ expects as input a finite element mesh

$\%$ described by the fields coordinates, elements,

$\%$ dirichlet and neumann.

$\%$ The vector marked contains the indices of elements

$\%$ which are refined by red-refinement,

$\% \quad$ i.e. which are split into 4 similar triangles.

$\%$

$\%$ The function returns the refined mesh in terms of

$\%$ the same data as for the input.

$\%$ Remark:

$\%$ This program is a supplement to the paper

$\%$ "Efficient Implementation of

\% Adaptive P1-FEM in Matlab"

$\%$ by S. Funken, D. Praetorius, and P. Wissgott.

$\%$ The reader should consult that paper for

$\%$ more information.

$\%$

\%Athors:

$\%$

\% S. Funken, D. Praetorius, P. Wissgott 10-07-08

markedElements $=$ varargin $\{$ end $\} ;$

$\mathrm{nE}=\operatorname{size}($ elements, 1$) ;$

\%*** Sort elements such that first edge is longest

$\mathrm{dx}=$ coordinates (elements $(:,[2,3,1]), 1)-\ldots$ coordinates (elements, 1$)$;

$\mathrm{dy}=$ coordinates (elements $(:,[2,3,1]), 2)-\ldots$ coordinates (elements, 2$)$;

$[\mathrm{hT}, \mathrm{idxMax}]=\max \left(\operatorname{reshape}\left(\mathrm{dx} \cdot{ }^{\wedge} 2+\mathrm{dy} \cdot{ }^{\wedge} 2, \mathrm{nE}, 3\right),[], 2\right)$; $\mathrm{idx}=(\operatorname{idxMax}==2)$; 


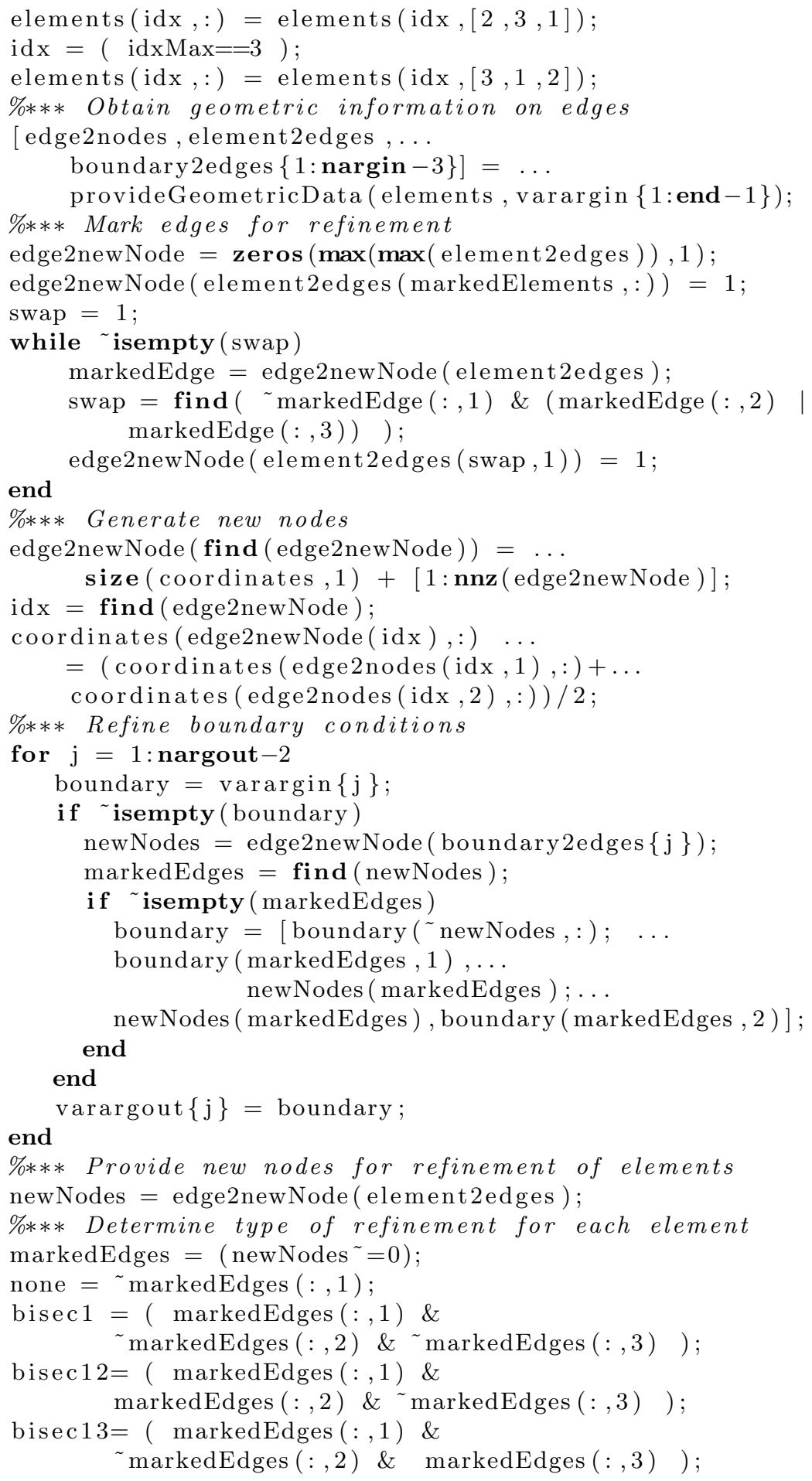




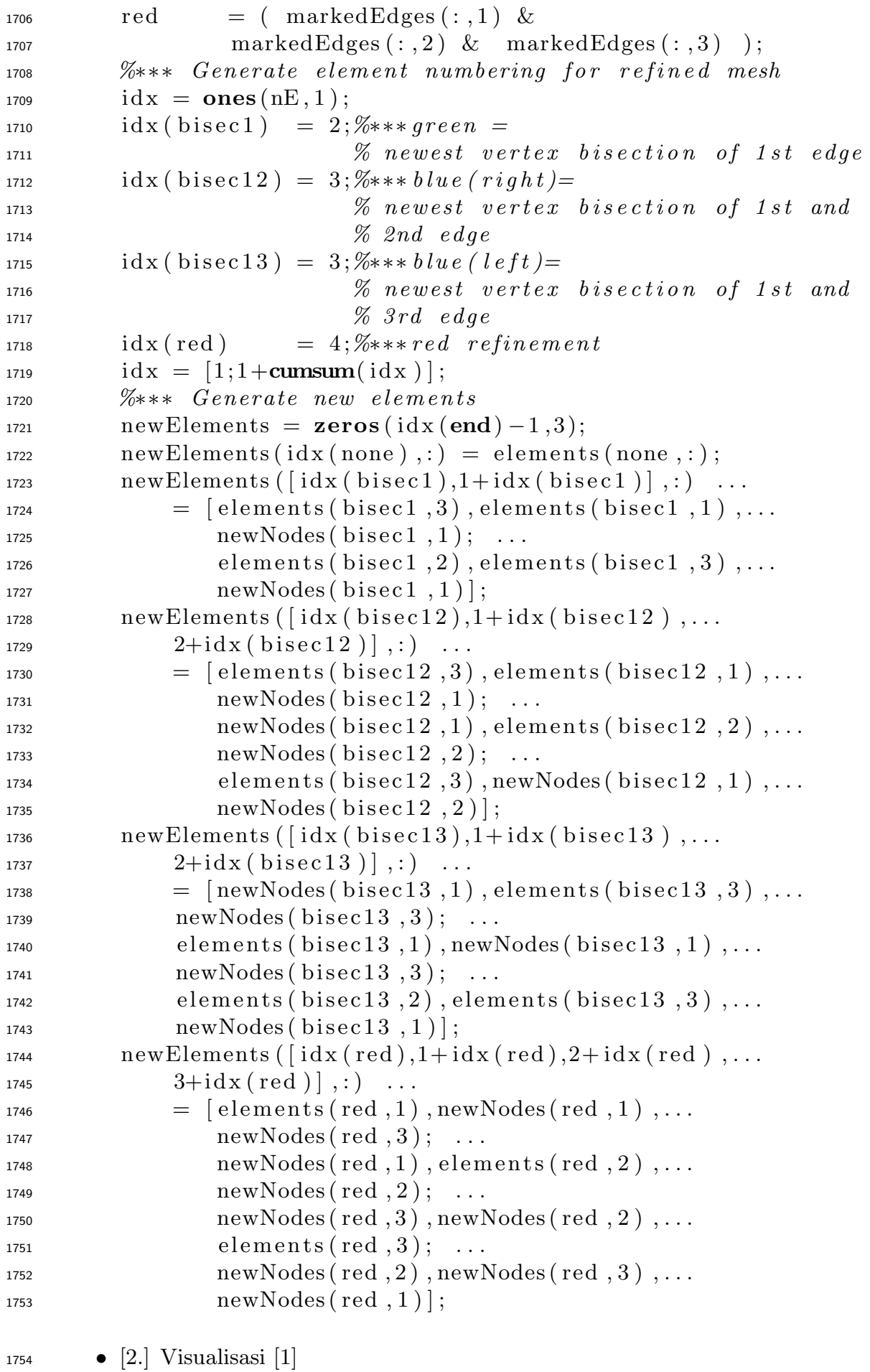




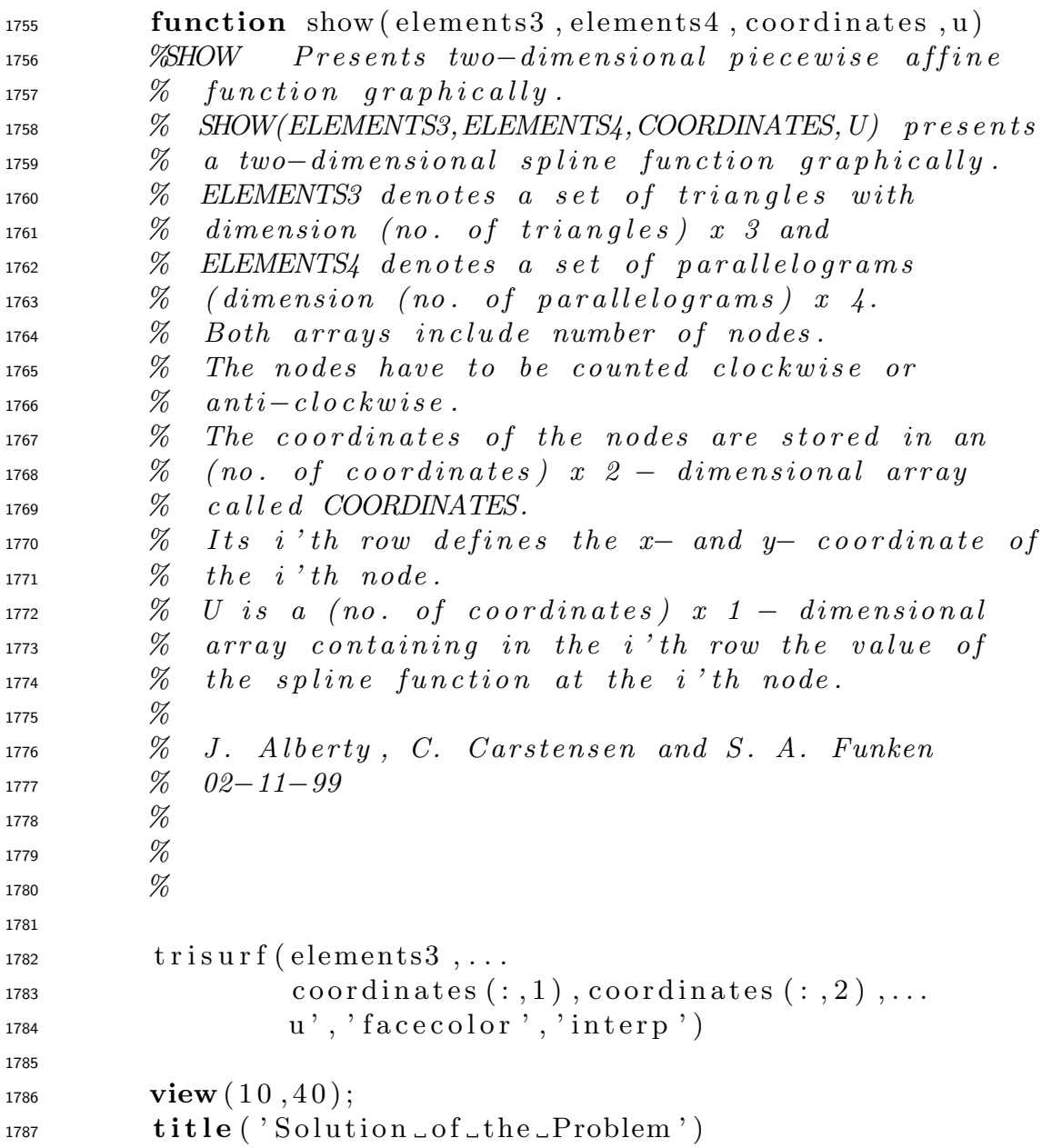




\section{LAMPIRAN 5 \\ Alat Bantu Matematika \\ Integration by parts.}

1. Rumus satu dimensi skalar

Integration by parts menyangkut variabel skalar di satu dimensi, dinyatakan sebagai berikut :

$$
\int_{x_{1}}^{x_{2}} u \frac{d v}{d x} d x=\left.u v\right|_{x_{1}} ^{x_{2}}-\int_{x_{1}}^{x_{2}} \frac{d u}{d x} v d x
$$

2. Rumus integrasi untuk vektor

Teorema divergensi yang diterapkan untuk fungsi $u \mathbf{F}, u$, dan $\mathbf{F}$, dapat dituliskan sebagai

$$
\int_{\Omega} \nabla \bullet(u \mathbf{F}) d \Omega=\int_{\partial \Omega}(u \mathbf{F}) \bullet \mathbf{n} d S
$$

Dengan menggunakan aturan perkalian untuk divergensi

$$
\nabla \bullet(u \mathbf{F})=(\nabla u) \bullet \mathbf{F}+u(\nabla \bullet \mathbf{F})
$$

Sehingga diperoleh

$$
\int_{\Omega} u(\nabla \bullet \mathbf{F}) d \Omega=\int_{\partial \Omega}(u \mathbf{F}) \bullet \mathbf{n} d S-\int_{\Omega}(\nabla u) \bullet \mathbf{F} d \Omega
$$

3. Teorema Green

Dengan substitusi $\mathbf{F}=\nabla u$, diperoleh rumus Green

$$
\int_{\Omega} u(\nabla \bullet \nabla u) d \Omega=\int_{\partial \Omega} u \nabla u \bullet \mathbf{n} d S-\int_{\Omega}(\nabla u) \bullet \nabla u d \Omega
$$




\section{LAMPIRAN 6}

Simbol dan satuan

\begin{tabular}{lcl}
\hline Konsep & Simbol & Satuan \\
\hline Intensitas medan listrik & $\mathbf{E}$ & Volt $/$ meter \\
Intensitas medan magnetik & H & Ampere $/$ meter \\
Kepadatan fluks listrik & $\mathbf{D}$ & Coulomb $/$ meter $^{2}$ \\
Kepadatan fluks magnetik & $\mathbf{B}$ & Tesla \\
Kepadatan arus listrik & $\mathbf{J}$ & Ampere $/$ meter $^{2}$ \\
Kepadatan muatan listrik & $\rho$ & Coulomb $/$ meter $^{3}$ \\
Muatan listrik & $Q$ & Coulomb \\
\hline
\end{tabular}

\begin{tabular}{lll}
\hline & & \\
\hline Konsep & Medan-Elektrik & Medan-Magnetik \\
& Medan-E & Medan-H \\
\hline Potensial skalar & {$[\phi]=\mathrm{V}$} & {$\left[\phi_{m}\right]=\mathrm{A}$} \\
Potensial vektor & {$[\mathbf{F}]=$ Coulomb/meter } & {$[\mathbf{A}]=\mathrm{Vs} / \mathrm{m}$} \\
Voltase & {$\left[V_{e}\right]=\mathrm{V}$} & {$\left[V_{m}\right]=\mathrm{A}$} \\
Kuat Medan & {$[\mathbf{E}]=\mathrm{V} / \mathrm{m}$} & {$[\mathbf{H}]=\mathrm{A} / \mathrm{m}$} \\
Flux & {$[\Psi]=\mathrm{As}$} & {$[\Phi]=\mathrm{Vs}($ Weber $)$} \\
Densitas Flux & {$[\mathbf{D}]=\mathrm{As} / \mathrm{m}^{2}$} & {$[\mathbf{B}]=\mathrm{Vs} / \mathrm{m}^{2}($ Tesla $)$} \\
Densitas Vorteks & {$[\nabla \times \mathbf{E}]=\mathrm{V} / \mathrm{m}^{2}$} & {$[\nabla \times \mathbf{H}]=\mathrm{A} / \mathrm{m}^{2}$} \\
Densitas sumber & {$[\nabla \bullet \mathbf{D}]=\mathrm{As} / \mathrm{m}^{3}$} & {$[\nabla \bullet \mathbf{B}]=\mathrm{Vs} / \mathrm{m}^{3}$} \\
Konduktifitas diperumum & {$\left[\varepsilon=\frac{\mathbf{D}}{\mathbf{E}}\right]=\mathrm{As} / \mathrm{Vm}$} & {$\left[\mu=\frac{\mathbf{B}}{\mathbf{H}}\right]=\mathrm{Vs} / \mathrm{Am}$}
\end{tabular}




\section{LAMPIRAN 8}

Glosarium

- Persamaan Differensial Biasa (PDB).

Ekspresi berbentuk $F\left(x, u(x), \frac{d u}{d x}, \cdots, \frac{d^{n} u}{d x^{n}}\right)=0$ untuk variabel bebas $x$ dan fungsi $u(x)$ beserta turunan dari $u$, yaitu $\frac{d u}{d x}, \cdots, \frac{d^{n} u}{d x^{n}}$. Persamaan differensial dinamakan persamaan differensial biasa berorde- $n$.

- Persamaan Differensial Parsial (PDP).

Ekspresi berbentuk $F\left(x_{i}, u\left(x_{i}\right), \frac{\partial u}{\partial x}, \cdots, \frac{\partial^{n} u}{\partial x^{n}}\right)=0$ untuk multi-variabel bebas $x_{i}$ dan fungsi $u\left(x_{i}\right)$ beserta turunan parsial dari $u$, yaitu $\frac{\partial u}{\partial x_{i}}, \cdots, \frac{\partial^{n} u}{\partial x^{n}}$.

- Syarat Awal.

Untuk PDB berorde- $n$ yang didefinisikan di $[a, b]$, apabila diberikan persyaratan pada fungsi $u$ dan turunan-turunannya sampai turunan ke- $(n-1)$ pada titik $a$. Untuk PDP berorde- $n$ yang didefinisikan di $[a, b]^{m}$, apabila diberikan persyaratan pada fungsi $u$ dan turunan-turunannya sampai turunan parsial ke- $(n-1)$ pada batas $\{a\} \times[a, b]^{(n-1)}$.

- Syarat Batas.

Untuk PDB berorde- $n$ yang didefinisikan di $[a, b]$, apabila diberikan persyaratan pada fungsi $u$ dan turunan-turunannya sampai turunan ke- $(n-1)$ pada titik $a$ dan $b$.

Untuk PDP berorde- $n$ yang didefinisikan di $[a, b]^{m}$, apabila diberikan persyaratan pada fungsi $u$ dan turunan-turunannya sampai turunan parsial ke- $(n-1)$ pada batas domain $[a, b]^{n}$.

- Syarat Batas Dirichlet.

Untuk PDP berorde- $n$ yang didefinisikan di $[a, b]^{m}$, apabila diberikan persyaratan pada fungsi $u$ pada batas domain $[a, b]^{n}$.

- Syarat Batas Neumann.

Untuk PDP berorde- $n$ yang didefinisikan di $[a, b]^{m}$, apabila diberikan persyaratan pada turunan-turunan dari fungsi $u$ pada batas domain $[a, b]^{n}$.

- Syarat Batas Campuran.

Untuk PDP berorde- $n$ yang didefinisikan di $[a, b]^{m}$, apabila diberikan persyaratan pada fungsi $u$ serta turunan-turunannya sampai turunan parsial ke- $(n-1)$ pada batas domain $[a, b]^{n}$. 


\section{${ }_{1837}$ Tentang Penulis}

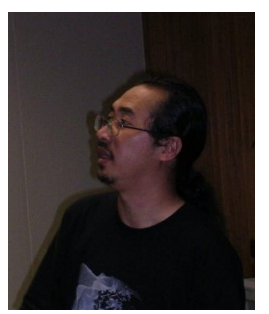

Agah D Garnadi lulus Sarjana Matematika dari Institut Teknologi Bandung, dengan konsentrasi Matematika Murni. Mendapatkan pendidikan Pasca Sarjana dalam bidang Scientific Computing dengan minor matematika murni dari The Australian National Universty, Canberra, Australia. Sempat bekerja sebagai asisten peneliti dalam Metode Elemen Hingga di Dept. Engineering, ANU. Atas biaya DAAD mendalami bidang Teknomathematik dan Finanzmathematik di TU-Kaiserslautern, Jerman. Kemudian bekerja sebagai Scientific Programmer selama dua tahun di Crystal Growth Group, CAESAR, Bonn, dengan tugas utama perancangan dan simulasi tungku kristal industri semikonduktor. Kemudian selama 4 tahun berkesempatan menjadi peneliti tamu di Institut fuer Numerische und Angewandte Mathematik, Georg-August Universitaet Goettingen.

SINTA ID : 6015353

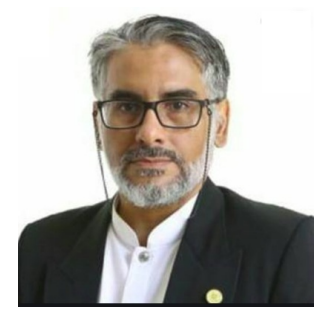

Husin Alatas lulus S1 Fisika, dari Institut Teknologi Bandung; Dilanjutkan S2 dan S3, juga di Institut Teknologi Bandung. Post-Doctoral di University of Twente, The Netherlands, dalam bidang Fisika Nonlinear.

Terhitung dari tahun 2017, diangkat sebagai Guru Besar Fisika Teori di Institut Pertanian Bogor.

SINTA ID : 5979618 


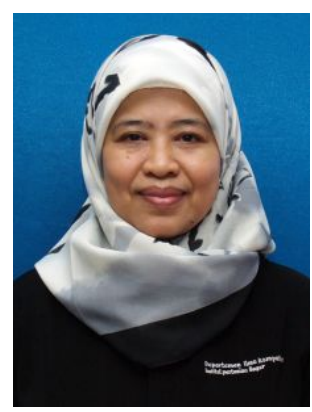

Sri Nurdiati lulus Sarjana dari Departemen Statistika FMIPA IPB. Kemudian, ia melanjutkan pendidikan S2 Ilmu Komputer di The University of Western Ontario, Canada. Pendidikan S3 ditempuh di Twente University, The Netherlands, dengan mengambil bidang Matematika Terapan.

SINTA ID : 6042844

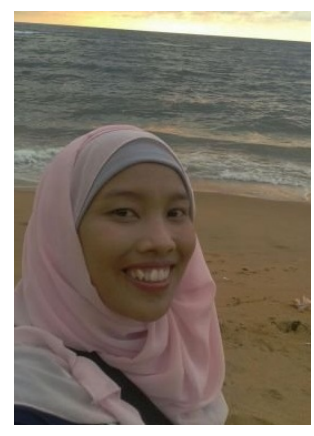

Lia Yuliawati lulus program sarjana di Departemen Matematika FMIPA IPB. Kemudian, ia melanjutkan pendidikan S2 Matematika Terapan di IPB. Pendidikan S3 ditempuh di Institut Teknologi Bandung, dengan mengambil bidang Matematika Terapan.

SINTA ID : 6004495 